\title{
The use of price and non-price performance measures in debt and compensation contracts
}

Citation for published version (APA):

Roomberg, R. J. M. (2008). The use of price and non-price performance measures in debt and compensation contracts. [Doctoral Thesis, Maastricht University]. Maastricht University. https://doi.org/10.26481/dis.20080904rr

Document status and date:

Published: 01/01/2008

DOI:

10.26481/dis.20080904rr

Document Version:

Publisher's PDF, also known as Version of record

\section{Please check the document version of this publication:}

- A submitted manuscript is the version of the article upon submission and before peer-review. There can be important differences between the submitted version and the official published version of record.

People interested in the research are advised to contact the author for the final version of the publication, or visit the DOI to the publisher's website.

- The final author version and the galley proof are versions of the publication after peer review.

- The final published version features the final layout of the paper including the volume, issue and page numbers.

Link to publication

\footnotetext{
General rights rights.

- You may freely distribute the URL identifying the publication in the public portal. please follow below link for the End User Agreement:

www.umlib.nl/taverne-license

Take down policy

If you believe that this document breaches copyright please contact us at:

repository@maastrichtuniversity.nl

providing details and we will investigate your claim.
}

Copyright and moral rights for the publications made accessible in the public portal are retained by the authors and/or other copyright owners and it is a condition of accessing publications that users recognise and abide by the legal requirements associated with these

- Users may download and print one copy of any publication from the public portal for the purpose of private study or research.

- You may not further distribute the material or use it for any profit-making activity or commercial gain

If the publication is distributed under the terms of Article $25 \mathrm{fa}$ of the Dutch Copyright Act, indicated by the "Taverne" license above, 
The Use of Price and Non-Price

Performance Measures

in Debt and Compensation Contracts 
(C) Copyright R.P.J.M. Roomberg, Maastricht 2008 ISBN 9789052787398

Printed by Datawyse / Universitaire Pers Maastricht 


\title{
The Use of Price and Non-Price \\ Performance Measures \\ in Debt and Compensation Contracts
}

\author{
PROEFSCHRIFT
}

ter verkrijging van de graad van doctor aan de Universiteit Maastricht, op gezag van de Rector Magnificus, Prof. Mr. G.P.M.F. Mols volgens het besluit van het College van Decanen in het openbaar te verdedigen op donderdag 4 september 2008 om 14.00 uur

door

Robbert-Paul Jacco Martijn Roomberg

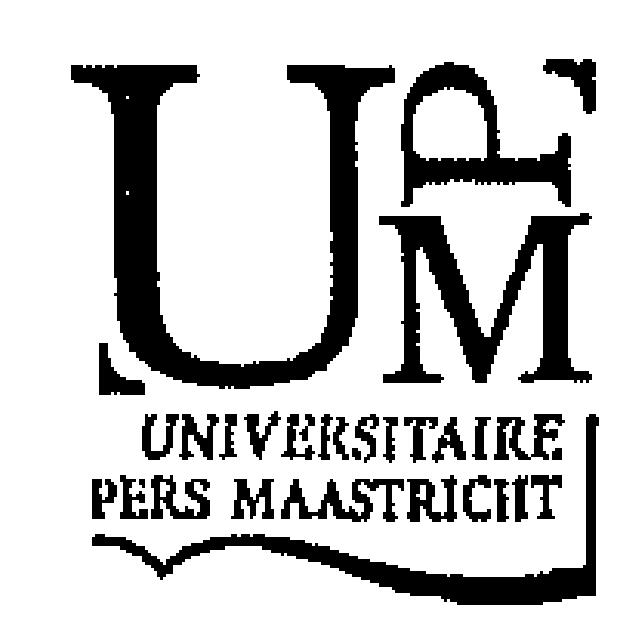




\section{Promotor}

Prof. dr. F. Moers

\section{Copromotor}

Dr. E. Peek

\section{Beoordelingscommissie}

Prof. dr. R. Meuwissen (voorzitter)

Prof. dr. M. Carree

Prof. dr. J. Bouwens (Universiteit van Tilburg) 


\section{Contents}

Acknowledgements VIII

Chapter 1:

Introduction 1

1.1 Introduction 1

1.2 Outline 3

1.3 Contribution 6

Chaperer 2 :

The reliability of small businesses' accounting information 9

2.1 Introduction 9

2.2 Theory and hypotheses 11

2.3 Data 14

2.4 Measures 15

2.4.1 Measuring the reliance on debt capital 15

2.4.2 Measuring monitoring intensity 16

2.4.3 Measuring relationship financing 17

2.4.4 Control variables 17

2.5 Research methodology 19

2.6 Descriptive analysis 21

2.7 Results 25

2.8 Summary and conclusion $\quad 29$

Chapter 3:

The relation between CEO equity incentives and performance measures in CEO annual bonus contracts 31

3.1 Introduction 31

3.2 Theory and hypotheses 34

3.3 Data 36

3.4 Measures 37

3.4.1 Definition of CEO equity incentive measures and the use of nonaccounting measures $\quad 37$

3.4.2 Control variables 38

$\begin{array}{lll}3.5 & \text { Research methodology } & 41\end{array}$

3.6 Descriptive analysis 43

3.7 Results 48

3.8 Summary and conclusion $\quad 52$ 
Chapter a:

Option-based equity incentives and earnings management: the role of performance measures in annual bonus contracts

4.1 Introduction 53

4.2 Theory and hypothesis 56

4.3 Data 57

4.4 Measures 58

4.4.1 Definition of earnings management measures 58

4.4.2 Definition of CEO option compensation measures 59

4.4.3 Definition of the use of non-accounting measures 59

4.4.4 Control variables 60

4.5 Research methodology 62

4.6 Descriptive analysis 64

$\begin{array}{lll}4.7 & \text { Results } & 67\end{array}$

$\begin{array}{lll}4.8 & \text { Summary and conclusion } & 74\end{array}$

Chapter 5 :

Summary and conclusion $\quad 77$

$\begin{array}{lll}5.1 & \text { Introduction } & 77\end{array}$

$\begin{array}{lll}5.2 & \text { Summary } & 77\end{array}$

5.3 Limitations and suggestions for future research 80

5.4 Conclusion and implications 81

$\begin{array}{ll}\text { Appendices } & \mathbf{8 5}\end{array}$

Appendix A. Estimating sensitivities of individual stock options 86

Appendix B. Estimating earnings management proxies 87

$\begin{array}{ll}\text { References } & 91\end{array}$

$\begin{array}{ll}\text { Summary in Dutch } & 97\end{array}$

$\begin{array}{lr}\text { Curriculum Vitae } & 102\end{array}$ 


\section{Acknowledgements}

While thinking about the past years, doing what I did, writing what I wrote, it all appears to me as a flight on an airplane, or actually even learning how to fly an airplane. To illustrate this, just imagine whether you have ever considered leaving a flying airplane. Even though it's possible, I assume it's highly unlikely. In a similar way, I have always wanted to stay aboard during this flight, and fortunately, a lot of people made that same decision with me.

Just like a flight ends by thanking the captain and his crew, I definitely owe a lot to many people who accompanied me on the plane. In the first place there is the captain and the co-pilot, my supervisors, Frank Moers and Erik Peek. Frank, I specifically thank you for your research ideas, methodological support, prompt and direct evaluation of all my work and of course your ability to teach me how to bring a point across in writing. Erik, I wish to thank you for your conceptual input, critical attitude and the combination of very broad but also very specific remarks on several statistical, textual and SAS related issues. Both of you made me wiser in your own way.

In cases of foreign flights, there are also the customs officers asking whether I have anything to declare. In this case, that has been the job of the dissertation committee consisting of Roger Meuwissen, Martin Carree and Jan Bouwens. I thank all three for their evaluation and approval of the final version of the manuscript. Each one of you has provided constructive comments and suggestions and I would specifically like to thank Martin Carree for his econometric feedback.

Another notable event on any flight is the meal. On this flight reflected by the daily Mensa lunch. I leave it open for discussion to base this comparison on the quality of the food, more importantly, I wish to thank all the Mensa joiners for their joyful distraction and company.

With the benefit of hindsight, I might have considered taking a Concorde, but on the other hand if you have nice people sitting around you on the plane, time flies by very quickly. Of course my current colleagues at PricewaterhouseCoopers and my former colleagues at Maastricht University have all added to a pleasant and constructive work environment, but a special thanks goes to my fellow PhD students Felix, Rick, Alexander and Ling.

Finally, there are family and friends, some that were sitting on the plane with me, some that were waiting for the plane to arrive. In particular I wish to thank opa Arnold, Paul, Lily, Roen and Rim. Each of you has provided distraction, encouragement, practical support (layout!), understanding, patience, trust, a million things to laugh about and above all, a great place to always feel at home! 
Even though it might have been a bumpy flight at some point in time, a final reason that it has been a flight, and nothing more than a flight, is that the journey is still to come. I hope you are all coming along.

Robbert-Paul Roomberg, Frankfurt am Main, July 2008 


\section{Chapter 1}

\section{Introduction}

\subsection{Introduction}

This dissertation studies the use and effects of price and non-price performance measures in debt and compensation contracts. Throughout this dissertation, 1 use two operational measures for the use of price measures (e.g., Core and Guay, 1999; Guay, 1999): the sensitivity of the executive's option and stock holdings to (1) stock price and/or (2) stock return volatility. All performance measures other than price-based measures are classified as non-price performance measures. I distinguish two groups of non-price measures: accounting and non-accounting. Common accounting performance measures used are revenues, net income and earnings growth. The non-accounting performance measures can take a variety of forms, ranging from quantitative measures, such as customer satisfaction, quality metrics, market share and new product introductions, to qualitative assessments such as the executive's individual performance.

Firms' accounting information is one of the most commonly used metrics to reduce information asymmetry between corporate managers and outside investors and debtholders. The widespread reliance on accounting information in control mechanisms, such as managerial compensation plans and debt contracts, can be explained by the idea that the costs of collecting and processing audited, understandable, verifiable, standardized and fairly objective signals from the accounting system are low relative to alternative contracting measures. In spite of these inherently positive characteristics of accounting information, contracts based on accounting performance have been criticized for encouraging managers to influence the financial reporting process. As illustrated in figure 1.1 , this drawback of the contractual use of financial accounting figures is addressed in chapter 2 of this dissertation. More specifically, I study the role of accounting performance in small business lending. I examine whether creditors' focus on earnings influences management's accounting choices to reduce the cost of external financing. 
Besides the concern that accounting based performance measures influence the financial reporting process, there are more shortcomings to the contractual use of accounting performance measures. While accounting information may fully capture the financial effect of short-term operating decisions, it may not perfectly capture the longer term effects of other actions such as a Chief Executive Officer's (CEO) current strategic planning, or investments in the development of new products with deferred returns. This affects managers' risk appetite and is likely to lead to overly conservative actions to preserve short-term financial results. Consequently, most firms include additional performance measures in their contracts that supplement accounting measures to overcome the short-run and risk aversive orientation of accounting-based reward systems. The most commonly used forward-looking performance measure in CEO compensation contracts is stock price. To the extent that stock prices incorporate how current actions will affect future profitability, the use of price-based performance measures motivates long-run value creation. While price measures address concerns about the decision-making horizon of managers and also help overcome managers' natural aversion to risk, they remain silent on the specific risks that shareholders would like managers to take and also expose executives to market-wide movements in stock prices. As illustrated in figure 1.1, these concerns are addressed in chapter 3 .

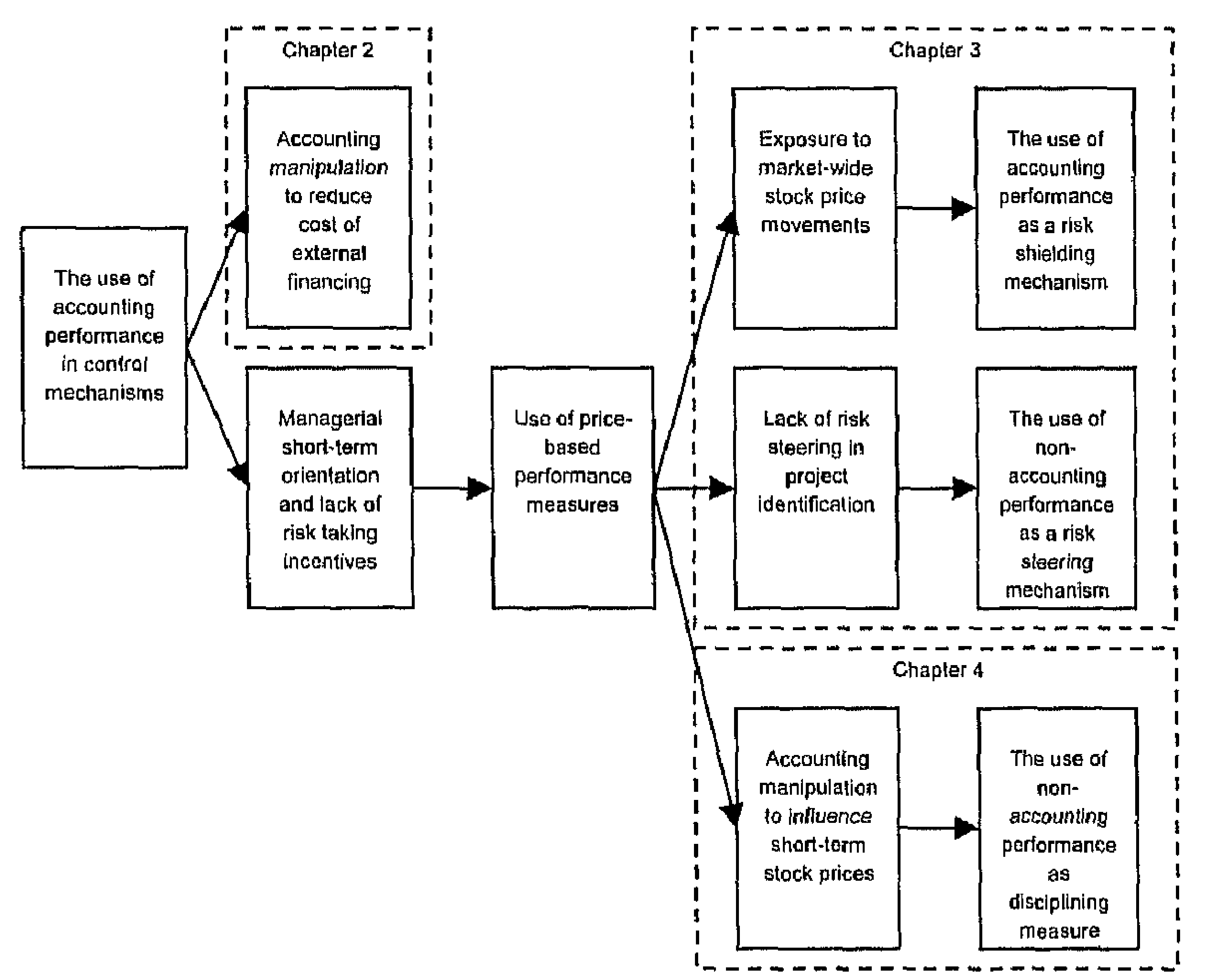

Figure 1.1 The use of price and non-price performance measures in debt and compensation contracts. 
More specifically, I study how non-price performance measures are used to deal with the inherent limitations of price-based performance measures. I argue that firms using price-based performance measures have an incentive to also use accounting earnings in the compensation contract to shield executive compensation from market-wide movements in stock price. Additionally, $I$ argue that nonaccounting performance measures have a risk steering role. This means that they supplement price measures to identify those risky positive Net Present Value (NPV) projects that shareholders do not want to forego.

Chapter 4 addresses another link between the use of price- and non-pricebased performance measures. As illustrated in figure 1.1, price-based performance measures might induce managers to increase the short-term stock price through earnings management. $I$ argue that option related earnings management decreases once compensation contracts also include non-accounting performance measures. More specifically, I predict that executive payments based on non-accounting performance help investors to infer the permanence of current earnings. That is, a combination of high earnings and low bonus pay indicates that accounting and non-accounting performance diverge. This illustrates that non-accounting performance measures in compensation contracts act as disciplining measures, making earnings management less effective in influencing short-term stock prices.

\subsection{Outline}

The body of this dissertation consists of three empirical studies. Chapter 2 studies the role of accounting information in small business lending. Since small businesses often lack a publicly available track record, creditors face high uncertainty about these firms' creditworthiness. As a consequence, small businesses often face difficulties in raising capital at reasonable rates. As potential and existing lenders are likely to offer better terms of transactions if they perceive a firm to be less likely to default or delay loan payments, firms have an incentive to influence the information they provide to their lenders. Given the lack of publicly available information on small businesses, their self-supplied accounting performance becomes a decisive source of information in assessing their creditworthiness. In the absence of third-party auditing and following the transactions costs theory, I expect that the more emphasis lenders place on accounting earnings in establishing the terms of transactions with a firm, the stronger the incentives are for a firm to misreport earnings in order to improve the terms of transactions between the firm and its lender.

My study focuses on one important manifestation of earnings management: earnings management to avoid reporting a loss. I predict that stakeholders' focus on earnings thresholds influences management's accounting choices when 
being close to these thresholds. More specifically, this means that stakeholders' (i.e. lenders') aversion to losses results in firms (i.e. borrowers) avoiding reporting losses. I restrict my attention to manager-owned firms, to provide evidence that in the absence of traditional principal-agent conflicts, firms still have incentives to misreport earnings. In my analyses, I distinguish three drivers of lenders' use of accounting information. I hypothesize that loss avoidance is positively related to small businesses' reliance on debt capital and negatively related to small businesses' use of relationship financing and their lenders' monitoring intensity. Knowledge of these drivers may help practitioners in assessing the trustworthiness of small businesses' self-supplied accounting information. This is important because little is known about the reporting behavior of small businesses even though they play a crucial role in the economy.

In chapter 3, l examine to what extent the use of stock price as a performance measure in CEO compensation is linked to the use of non-price performance measures. ${ }^{1}$ Modern corporations frequently encourage managerial ownership to align managerial actions with shareholder's interests. In particular, managers often receive options or shares of stock to increase the level of managerial ownership. Besides the incentive-alignment effect of managerial ownership and stock-based compensation, these elements also expose managers to wealth fluctuations that are beyond their control. In addition, while some of these equity incentive elements can encourage managerial risk taking, they do not specify the specific risk that shareholders would like managers to take. These shortcomings of equity-based pay leave room for other performance measures to improve contracting, and overcome deficiencies in price-based performance measures. In chapter 3, I explicitly examine the interrelations among performance measures in CEO compensation contracts. In particular, I consider the following equity incentive elements: the sensitivity of CEO stock and option portfolio holdings to stock price and the sensitivity of CEO stock option portfolio holdings to stock return volatility.

An increase in the sensitivity of managers' wealth to stock price induces managers to take actions that increase equity value, thereby encouraging longrun value creation. However, at the same time, since stock prices are affected by industry and market effects, an increase in the sensitivity of managers' to stock price also exposes managers to stock price movements that are unrelated to the manager's contribution to the firm. Thereby, the sensitivity to price leads firms to employ other mechanisms to protect CEOs from the wealth effects resulting from events beyond their control. Specifically, I argue that firms employ readily avail-

\footnotetext{
${ }^{1}$ While the contract data used for the studies in chapter 3 and 4 of this dissertation stems from CEO compensation contracts, the terms CEO and manager are used interchangeably throughout this dissertation.
} 
able accounting performance measures in the CEO's annual bonus to shield the CEO from market-wide risks in equity values and also ensure short-term operational performance.

In addition to the sensitivity of managers' wealth to stock price I also consider the sensitivity of managers' wealth to stock return volatility. The sensitivity of managers' wealth to stock return volatility induces managers to take more risk and invest in risk-increasing, positive NPV projects. However, while the sensitivity of CEO wealth to stock return volatility helps to overcome managers' natural aversion to risk, it does not specify the direction of managerial action to specific risks. I argue that firms employ non-accounting performance measures in CEO annual bonus contracts to direct $C E O$ s attention towards those risk areas that shareholders want to see addressed. For example, while risky new product development will to a certain extent be ensured by an increase in the sensitivity of the manager's wealth to stock return volatility, an additional incentive to achieve this specific goal will most likely be provided by the use of nonaccounting measures related to the achievement of product development milestones. My analysis in chapter 3 shows that non-price performance measures (accounting and non-accounting performance measures) are, indeed, used as a way to remedy the adverse consequences arising from price-based performance measures.

Chapter 4 provides an analysis of the relation between CEO stock option compensation and earnings management when non-accounting performance measures are used in the CEO's annual bonus contract. While stock options are commonly used in executive compensation contracts to align the interests of executives with those of shareholders, stock option compensation also creates opportunistic incentives for managers. For example, to the extent that market participants use earnings to forecast firm value, managers have an incentive to manage earnings to influence market participants' firm value forecasts and thereby increase the value of their stock options. The ability of earnings management to be effective in influencing stock prices depends on the availability of other relevant information. In this sense, information is relevant if it allows an evaluation of the permanence of current changes in earnings. For example, when managers report high earnings but do not receive a correspondingly high bonus, market participants are likely to infer that high bonus payouts would be unwarranted given the firm's non-accounting performance. This affects market 
participants firm value forecasts and indicates that non-accounting measures act as a disciplining measure to curtail option-driven earnings management. ${ }^{2}$

The use of non-accounting performance information in firm valuation decisions will be stronger for firms that place more weight on non-accounting performance measures in the annual bonus contract, because these firms' bonus payments contain more information about future performance. Since earnings management is less likely to influence these firms' stock price, I predict that managers in these firms manage earnings less. Therefore, $I$ examine whether greater reliance on non-accounting performance measures in CEO annual bonus contracts decreases the influence of options-based pay on earnings management.

\subsection{Contribution}

This dissertation contributes to the literature in a number of ways. The study in chapter 2 addresses the question whether manager-owned small businesses, with limited access to capital markets, manage accounting performance to influence lenders' assessments of the firm. My results indicate that small businesses' loss avoidance is positively associated with the probability that lenders use earnings-based heuristics. This knowledge is helpful to practitioners in assessing the trustworthiness of small businesses' self-supplied accounting information. Furthermore, it shows that firms still have incentives to misreport earnings even in the absence of traditional principal-agent conflicts.

The study in chapter 3 provides an analysis of the interrelation between price and non-price-based performance measures in CEO compensation contracts. My tests contribute to the literature by distinguishing two price-based incentive elements: the sensitivity of manager's equity portfolio holdings to stock price and stock option portfolio holdings to stock return volatility. While both elements align the incentives of executives with the interests of shareholders, these measures also expose risk to managers and shareholders. I contribute to the literature by showing that different types of non-price performance measures address different kinds of risk related problems inherent to the use of pricebased performance measures. More specifically, I find that accounting measures are used to reduce risk from equity-based pay whereas non-accounting measures steer risky decision making in the direction desired by shareholders.

\footnotetext{
2 A Dutch newspaper article on the bonus pay to Philips' top management shows that Philips' top managers did not receive target bonus payments for 2007, whereas Philips achieved all its publicly communicated goals for the same period. This illustrates that management must have had non-public goals which, were not achieved. The article addresses this issue and thereby shows the relevance of the information included in bonus payments (NRC, February 19, 2008).
} 
Hereby, I provide evidence that CEO compensation committees employ different contract components to establish the optimal level of portfolio incentives.

The study in chapter 4 examines to what extent the relation between CEO stock option compensation and earnings management is affected by the use of non-accounting performance measures in CEO annual bonus contracts. Consistent with my hypothesis, I find that greater reliance on non-accounting performance measures in CEO annual bonus contracts decreases earnings management aimed at influencing the value of the CEO's newly granted stock options. This finding shows that the reliance on non-accounting performance measures in CEO annual bonus contracts curtails option-driven earnings management. Thereby, my results illustrate the relevance of annual bonus contracts in times where bonus pay has become small relative to option compensation. As such, my findings will be relevant for corporate executive compensation committees that evaluate compensation contracts for managers. Additionally, my evidence implies that future studies on the relation between earnings management and executive compensation should consider the interplay between existing compensation components. 


\section{Chapter 2}

\section{The reliability of small businesses' accounting information}

\subsection{Introduction}

Small businesses often face difficulties in raising capital at reasonable rates (e.g., Petersen and Rajan, 1994). ${ }^{3}$ Since these firms are relatively young, informationally opaque, and rarely followed by information intermediaries, such as analysts, rating agencies, or the financial press, (potential) lenders face high uncertainty about management's trustworthiness and competence (e.g., Berger and Udell, 1998). As a consequence, firms' self-supplied financial reports become one of the most crucial information items to lenders in assessing the firms' ability to repay a loan (e.g., Beaulieu, 1994). Given the potential conflicts of interest that exist between small businesses' owner-managers and outside suppliers of capital and in the absence of third-party auditing, the question arises which factors determine the reliability of such self-supplied information. This question is important because little is known about the reporting behavior of small businesses even though they play a crucial role in the economy. In this chapter, I test whether and when manager-owned small businesses misreport accounting performance to influence lenders' assessments of the firm.

I restrict my attention to manager-owned firms to abstract from the influence of information asymmetry between owner and manager on management's financial reporting decisions (Ang et al., 2000; Beatty and Harris, 1999). Financial intermediaries such as banks play a crucial role in facilitating small (manager-owned) firms' access to finance by screening, contracting with, and monitoring the firms they lend to (Berger and Udell, 1998). Although the literature contains evidence that small businesses' informational opacity influences the characteristics of their lending relationships (e.g., Boot, 2000; Elsas, 2005), little

\footnotetext{
${ }^{3}$ In this study, I define small businesses (or firms) as independent businesses having fewer than 500 employees. This definition is in accordance with the definition in the National Survey of Small Business Finances, my data source (Bitler et al., 2001; Cole and Wolken, 1995).
} 
is known about the reverse relationship. That is, how do lending characteristics influence the quality of information that small firms provide to their lenders? My focus on small businesses is useful in testing whether transactions costs are a determinant of firms' earnings management activities. ${ }^{4}$ Following the transactions costs theory, 1 expect that the more emphasis lenders place on accounting earnings in establishing the terms of transactions with the firm, the stronger the incentives are for the firm to misreport earnings (Bowen et al., 1995; Burgstahler and Dichev, 1997).

In this study, I identify three drivers of lenders' use of accounting information and examine their relationship with earnings management. First, I expect that small businesses that heavily rely on debt financing, i.e., have large lines of credit and stretch their current liabilities, anticipate applications for additional or renewed, mostly unsecured loans. Since the cash-generating ability of firms with high reliance on debt is essential in obtaining additional or new debt capital, potential lenders are likely to focus on accounting information in their credit decisions. Such firms therefore have a strong incentive to manage earnings. Second, prior studies indicate that small businesses tend to develop close ties and build long-term relationships with their lenders (hereafter referred to as relationship financing) to lower borrowing costs and increase the availability of funds (Berger and Udell, 1995; Boot and Thakor, 1994; Cole, 1998; Degryse and Van Cayseele, 2000; Diamond, 1991; Stiglitz and Weiss, 1983). The existence of these close firm-lender relationships provide lenders "soft", non-accounting information about firms' activities and decrease the importance of accounting information in lenders' credit decisions (Petersen and Rajan, 2002). Further, relationship lenders evaluate the profitability of their customers through multiple interactions (Boot, 2000), which reduces their reliance on single-year performance measures. I therefore argue that in such situations firms have weak incentives to manage accounting performance. Finally, in a similar spirit, small businesses may allow close monitoring by lenders, thereby reducing the incentives for earnings management since close monitors obtain "soft" information which substitutes for accounting information.

The role of accounting information in small business lending has been largely overlooked, partly due to a lack of data availability. My data comes from the National Survey of Small Business Finances (NSSBF), which contains detailed cross-sectional information on small businesses. A shortcoming of this survey is that the accounting items of concern are available for only one year (Petersen and Rajan, 1997). This allows me to investigate one important manifestation of earnings management, i.e., firms' avoidance of reporting small

\footnotetext{
${ }^{4}$ In this study, I define earnings management as managers' misuse of their discretion in making financial reporting decisions with the intention to mislead the users of the financial statements.
} 
losses (hereafter referred to as loss avoidance), but prevents me from examining firms' financial reporting decisions in detail. The firms that $I$ investigate are all surveyed in the 1993 and 1998 versions of the NSSBF. These small firms have less than 500 employees, median assets of $\$ 473,456$ and a median age of 14 years. This emphasizes that most of these firms lack public scrutiny but have a normal record of performance, making the use of accounting information in loan transactions feasible.

Consistent with my theoretical arguments, I find that small businesses' loss avoidance is related to borrowing characteristics that reflect lenders' emphasis on accounting information. More specifically, I find that lenders' monitoring intensity as well as the use of relationship financing are negatively associated with loss avoidance. Furthermore, I find that firms with a higher reliance on debt capital are more likely to avoid reporting losses.

I contribute to the literature in three important ways. First, although small businesses' accounting information plays an important role in lenders' credit decisions, the academic literature lacks sufficient knowledge of the reliability of such information. I show that the reliability of accounting information varies significantly across small businesses. Second, by exploiting a unique dataset of small businesses' finance characteristics, I provide insights into three drivers of differences in the reliability of small businesses' accounting information, i.e., the reliance on debt financing, lenders' monitoring intensity, and the use of relationship financing. Knowledge of such drivers may help practitioners in assessing the trustworthiness of small businesses' self-supplied accounting information. Finally, I provide evidence that in the absence of traditional principal-agent conflicts, firms still have incentives to misreport earnings.

The remainder of this chapter is organized as follows. In section 2.2, I discuss the theory and develop the hypotheses. In sections 2.3-2.5, I describe the data and the research method, while I provide descriptive statistics in section 2.6. In section 2.7, I present the results of the empirical tests, and conclude in section 2.8 .

\subsection{Theory and hypotheses}

Previous research suggests that public firms with widely dispersed shareholdings and a constant awareness of their market valuation have stronger incentives to engage in earnings management than private firms (Beatty and Harris, 2003; Shleifer and Vishny, 1997). However, if earnings management can influence lenders' perceptions of firms' probability of default, small businesses with concentrated shareholdings are likely to manage earnings as well, especially given the significantly greater costs to such firms of accessing external capital (Mikhail, 1999). 
The main idea of my analysis is that small business managers opportunistically avoid reporting losses to decrease the costs imposed in transactions with their stakeholders. This "transactions costs" approach to loss avoidance rests on two assumptions (Burgstahler and Dichev, 1997). First, it assumes that information about earnings affects the terms of transactions between the firm and its stakeholders and that the terms of transactions are generally more favorable for firms with higher, rather than lower, earnings. The literature on commercial lending illustrates that this assumption is valid (see Beaulieu, 1994). Second, the costs of storing, retrieving, and processing information are sufficiently high that at least some stakeholders determine the terms of transactions with the firm based on heuristics such as using heuristic cut-offs at zero in evaluating earnings levels. Below, I define three hypotheses about how small businesses' borrowing characteristics affect lenders' heuristic use of accounting information, which subsequently affects small businesses' loss avoidance. First, however, I explain the rationale underlying the heuristic evaluation of earnings and its relation to loss avoidance.

In this study, I predict that stakeholders' focus on earnings thresholds influences management's accounting choices when being close to reporting zero earnings. This prediction is consistent with prior empirical evidence on loss avoidance by public U.S. firms (Burgstahler and Dichev, 1997; Degeorge et al., 1999). The use of heuristics such as using cut-offs in evaluating earnings is generally interpreted as a response to information costs (Conlisk, 1996). For example, Degeorge et al. (1999) argue that people rely on rules of thumb to reduce transactions costs. They suggest that banks may grant loans only to firms that report positive earnings because it may be too difficult to judiciously adjust loan prices in response to differential performance. Moreover, prospect theory identifies zero earnings as a natural reference point against which individuals evaluate changes in wealth (Kahneman and Tversky, 1979). Specifically, prospect theory predicts that individuals' disutility from a one cent decrease in wealth tends to be larger than individuals' utility from a one cent increase in wealth. Under the assumption that accounting performance, i.e., earnings, proxies for stakeholders' change in wealth, prospect theory may explain that stakeholders (such as lenders) evaluate reported earnings in reference to zero earnings. Lenders' focus on zero earnings may be even more pronounced than other stakeholders' focus since firms reporting a loss after interest expense disclose that current operating performance was insufficient to fulfill all interest obligations. I predict that since management is likely to focus on earnings thresholds if stakeholders do, stakeholders' aversion to losses results in firms avoiding reporting losses (Degeorge et al., 1999).

Given that lenders' heuristics are difficult to observe, I examine the potential drivers of lenders' focus on accounting information and their use of heuristics in 
THE RELIABILITY OF SMALL BUSINESSES' ACCOUNTING INFORMATION

evaluating accounting information. My first expectation is that small businesses' reliance on debt financing is positively related to the importance of accounting information in lending transactions and therefore positively affects loss avoidance. A distinguishing characteristic of debt capital is that lenders have the possibility to require securitization of their loans, for instance, by using working capital or fixed assets as collateral. If firms' reliance on debt financing increases then their marginal ability to borrow on a secured basis decreases, since not all assets are equally suitable as collateral. I therefore expect that the greater a firm's reliance on debt financing, the more emphasis lenders will place on operating performance, and consequently, the more (potential) lenders will focus on whether or not the firm reports a profit after current interest expense. More specifically, 1 expect that firms that heavily rely on debt financing anticipate future loans on an unsecured basis and therefore have strong incentives to avoid reporting losses. The following hypothesis applies:

H1: Management's choice to avoid reporting a loss is positively associated with the firm's reliance on debt capital.

Next to firms' reliance on debt capital, individual characteristics of the firmlender-relationships are also likely to affect firms' reporting behavior. The primary type of lender to small businesses are banks (Diamond, 1984; Fama, 1985; James, 1987; Petersen and Rajan, 2002), which play an important role as monitors. Initially, they identify the borrower's type and subsequently, they continuously monitor the actions of the borrower to safeguard their loans (Diamond, 1984; James, 1987; Petersen and Rajan, 2002). Gorton and Kahn (2000) argue that, in contrast to bonds, bank loans are typically held by a single lender. As the number of banks with which the firm deals increases, each bank's monitoring intensity may decrease due to potential free-rider problems (Carletti, 2004; Diamond, 1984) and these free-rider problems likely extend to other lenders' monitoring efforts (Bulow and Shoven, 1978). As a result, banks prefer to be the sole lender to reduce overall monitoring costs and to provide them with a voice in the firm's affairs. This improves their control but also reduces their use of earnings-based heuristics in credit decisions, which reduces firms' incentive to overstate reported earnings. I therefore state the following hypothesis:

H2: Management's choice to avoid reporting a loss is negatively associated with the monitoring intensity of the firm's lenders.

The lenders' identity also likely determines their reliance on financial records and accounting information. Petersen and Rajan (1994) argue that financial institutions have fairly specific loan application procedures, whereas non-financial 
firms and individuals are more likely to use "soft" information in the determination of the terms of a loan-contract. These latter parties are likely to develop close ties and relationships with their borrowers. The existence of relationship financing is likely to increase the importance of "soft" information in the lender's credit decision (Petersen and Rajan, 2002). Further, Boot (2000) argues that relationship lenders gather information about their customers through multiple interactions, thereby reducing their reliance on one single-year performance measure such as profits. Consequently, in comparison to financial institutions, the importance of accounting information in monitoring is likely to be smaller for the owner's family members or other individuals who can also act as lenders. I therefore expect that the latter category of lenders' extensive use of "soft" knowledge reduces the importance of earnings-based heuristics in their credit decisions. I test the following hypothesis:

H3: Management's choice to avoid reporting a loss is negatively associated with the existence of relationship financing.

\subsection{Data}

The data analyzed in this study are taken from the 1993 and 1998 versions of the National Survey of Small Business Finances (NSSBF). These surveys were funded by the Board of Governors of the Federal Reserve System and conducted in cooperation with the U.S. Small Business Administration in order to gather information about small businesses. Firms eligible for participation are all for-profit, non-financial, non-farm business enterprises that have fewer than 500 employees. The 1993 version of the survey contains 4,637 firms in operation as of year-end 1992. Although the survey sample may underrepresent many of the newest and smallest businesses, the firms in the sample are broadly representative of 4.99 million small businesses in the United States at the end of 1992. The 1998 version of the survey contains 3,561 firms in operation as of year-end 1998. Taking into account that the survey sample may underrepresent many of the newest and smallest businesses, the firms in the sample are broadly representative of 5.3 million small businesses in the United States at the end of $1998 .^{5}$

Firms in the survey report not only information on their balance sheet and income statement but also provide an extensive list of the entities with whom they have a business relationship. For example, firms are asked for all outstanding financial obligations to individuals, non-financial firms and financial

${ }^{5}$ For a detailed description of the 1993 NSSBF, see Cole and Wolken (1995). For a description of the 1998 NSSBF, see Bitler et al. (2001). 
institutions. ${ }^{6}$ The Federal Reserve project team evaluates the consistency between the dollar amounts of balance sheet items and income statement items and, where possible, verifies responses using hard-copy records. In some cases the project team also performs imputations to replace missing accounting data. I remove these observations from my sample. Data from the NSSBF appear in several prior studies (Berger and Udell, 1995; Cole, 1998; Petersen and Rajan, $1994,1997,2002)$ and are publicly available. ${ }^{7}$

My total sample consists of 8,198 firms. Since the data come from a survey of small businesses, it is likely that the profit figure is unaudited (Beaulieu, 1994; Petersen and Rajan, 1994). To reduce complications of comparing financial information across organizational forms, Ang et al. (2000) limit their sample of the 1993 NSSBF to small C-corporations. They argue that a focus on corporations minimizes problems associated with the financial statements of proprietorships, which typically commingle personal and business funds. Moreover, they justify an elimination of partnerships and S-corporations because these are not subject to corporate taxation. Because there is no double taxation, ownermanagers may take compensation in the form of distributions rather than salary expenses in these firms. For the same reason, I also replicate my analysis using a subsample of my data which contains only C-corporations. Below, I describe how I operationalize my independent variables. Subsequently, in section 2.5 I explain the two-stage approach I follow to estimate loss avoidance.

\section{$2.4 \quad$ Measures}

\subsubsection{Measuring the reliance on debt capital}

As argued, I expect that small businesses' reliance on debt capital positively affects their loss avoidance. To measure a firm's reliance on debt capital I first focus on the firm's line of credit (Petersen and Rajan, 1997). I prefer to focus on firms' lines of credit instead of total long-term liabilities since the former measure excludes loans that are secured by design, such as mortgages and vehicle loans, and therefore better captures firms' reliance on less secured debt capital. Firms included in the survey report both the portion of their line of credit that is as yet untapped as well as the maximum amount that can be drawn on their line of credit. I assume that firms with a higher maximum amount of credit are likely

\footnotetext{
${ }^{6} 1$ classify lines of credit, capital leases, business mortgages, equipment loans, motor vehicle loans and "other" loans as financial obligations. In both surveys, the term "other" loans refers to short-term loans, working capital loans, unsecured term loans, demand loans, and other loans not captured by the other 6 types of financial obligations.

7 NSSBF data can be found at the following web address: www.federalreserve.gov/pubs/oss/oss3/nssbftoc.htm.
} 
to rely more on external debt capital and therefore have stronger incentives to avoid loss reporting. In addition, I assume that firms that do not use the maximum amount that can be drawn on their line of credit still have funds at their disposal and thus have weaker incentives for loss avoidance.

I further measure the reliance on short-term credit as the amount by which a firm stretches its current liabilities, i.e., the value of a firm's current liabilities divided by its sales minus the corresponding industry average. Finally, I use a variable that measures whether a firm with limited access to institutional as well as internally generated funds is forced to obtain finance from alternative, usually, more expensive sources. Following the pecking-order theory (e.g., Myers, 1984), the amount of additional equity capital obtained during the fiscal year measures firms' inability to raise capital through more preferred sources (such as internal cash and debt). ${ }^{8}$

\subsubsection{Measuring monitoring intensity}

I expect that lenders' monitoring intensity negatively affects loss avoidance. To measure monitoring intensity I examine the concentration of loan obligations among different lenders interacted with a dummy variable measuring the presence of a loan obligation (i.e., when a loan obligation is present. As indicated in table 2.1, a loan obligation is present if a firm uses at least one of the following credit facilities: line of credit, capital lease, business mortgage, equipment loan, motor vehicle loan or "other" loans. The term "other" loans refers to short-term loans, working capital loans, unsecured loans, demand loans, and other loans not captured by the 6 other types of financial obligations). The concentration of loan obligations among the firm's different lending partners proxies for lenders' cost of monitoring. The risk of free-rider problems implies that lenders' claims on the project must be large enough to cover the monitoring costs. An increase in the relative importance of a single lender should therefore lead to more intense monitoring, which lowers lenders' use of earnings-based benchmarks and makes it less likely that a firm avoids reporting losses. I control in my analysis for the main effect of the dummy variable that measures the presence of a loan obligation. Including this variable is necessary to ensure that low values (close to zero) of the interaction between the concentration of loan obligations and the presence of a loan obligation can be correctly interpreted as the presence of dispersed loan obligations, as opposed to the absence of any loan obligations.

\footnotetext{
${ }^{8}$ Notwithstanding the different characteristics of debt and equity capital, I have included equity capital in this section since it is the ultimate form of unsecured financing and $I$ expect that firms using capital injections of this type have strong incentives to avoid reporting losses.
} 


\subsubsection{Measuring relationship financing}

I expect that the use of relationship financing reduces loss avoidance. My measure of the closeness of a borrower to its lenders is the fraction of outstanding loans across different types of lenders (i.e., when loan obligations are present). Consistent with Petersen and Rajan (1994) I distinguish financial institutions, non-financial firms and other individuals consisting of the owner and his family. ${ }^{9}$ । expect that a higher fraction of total firm borrowings coming from financial institutions increases the likelihood that a firm will report a small profit since the loan granting process of such institutions is characterized by the use of straightforward guidelines and hard (accounting) information (e.g., Danos et al., 1989; Beaulieu, 1994; Petersen and Rajan, 1994; Cole, 1998; Petersen and Rajan, 2002; Cole et al., 2004). In contrast, I expect the information collected by nonfinancial firms and individuals to be "soft" and therefore anticipate less loss avoidance when a higher fraction of total firm borrowings comes from nonfinancial firms, the owner's family or the owner himself (e.g., Petersen and Rajan, 1994).

\subsubsection{Control variables}

To control for firm characteristics that may affect loss avoidance, 1 include the firm's size and age. Since older firms have longer track records than younger firms, lenders' heuristic emphasis on near-term earnings may be less pronounced for older firms. Alternatively, prior studies indicate that accounting earnings tend to be more informative about firm performance for older firms (Black, 1998). If higher earnings informativeness implies that lenders focus more on earnings, this finding would imply a positive relationship between firm age and loss avoidance. Further, larger firms tend to have better developed information systems, potentially reducing outsiders' heuristic focus on reported earnings.

I also control for the age of the firm's primary owner, which proxies for owner experience, since experience may provide lenders with more assurance to repayment (Beaulieu, 1994). Similarly, firms maintaining good financial records may be perceived as less likely to fail and default (Cole et al., 2004). Therefore, I include a dummy variable indicating whether the firm used financial records in

\footnotetext{
${ }^{9}$ Consistent with Petersen and Rajan (1994), I classify commercial banks, savings and loans associations, savings banks, credit unions, finance companies, insurance companies, brokerage or mutual fund companies, leasing companies and mortgage banks as financial institutions. Loans made by nonfinancial firms consist of loans from government agencies, venture capitalist loans, and otherwise unclassified loans. The remaining loans consist of loans from the owner or family members of the owner.
} 
preparing survey responses. Finally, I include dummies for the survey year and the firm's organizational form. Table 2.1 summarizes my variable definitions.

Table 2.1 Variable definitions

Name of variable Description of variable

Panel A: Borrowing characteristics (BORROWING)

Reliance on debt capital

Line of credit: maximum The maximum amount that can be drawn on a firm's lines of credit divided amount

by the firm's sales

Line of credit: untapped The portion of a firm's lines of credit that is as yet untapped divided by the amount firm's sales

Reliance on short-term The value of the firm's current liabilities divided by the firm's sales minus the credit corresponding (two-digit SIC code) industry average

Additional equity amount

The amount of additional equity capital obtained during the most recent fiscal year divided by the firm's sales

Monitoring intensity

Presence of a loan obligation

Indicator variable that equals one if the firm uses at least one of the following credit facilities: line of credit, capital lease, business mortgage, equipment loan, motor vehicle loan or "other" loans (for a definition of "other" loans, see footnote 6)

Concentration of loan obligations

$S U M\left(\left(\frac{A M_{-} C L=n}{A M_{-} T O T_{-} C L}\right)^{2}\right)$

Herfindahl concentration index of loan obligations where $A M C_{-} n$ is the amount per claimant and AM_TOT_CL is the total amount of all claimants

Relationship financing

Fraction of total firm

The sum of all loans made by financial firms (loans from commercial banks, borrowing from financia institutions

savings and loans associations, savings banks, credit unions, finance companies, insurance companies, brokerage or mutual fund companies, leasing companies and mortgage banks) divided by the sum of all loans made to the firm

Fraction of total firm The sum of all loans made by non-financial firms (loans from government borrowing from nonfinancial firms agencies, venture capitalist loans, and otherwise unclassified loans) divided by the sum of all loans made to the firm

Fraction of total firm The sum of all loans made by the owner and his family divided by the sum borrowing from the owner and his family

Panel B: Firm characteristics (FIRM)

\begin{tabular}{ll}
\hline $\begin{array}{l}\text { Control variables } \\
\text { Total assets }\end{array}$ & End-of-year total assets \\
Firm age & The age of the firm in years \\
Owner age & The age of the firm's primary owner in years
\end{tabular}




\subsection{Research methodology}

To examine the relationship between small businesses' lending and firm characteristics and loss avoidance I follow a two-stage approach. In the first stage, I estimate the probability that firm $i$ reports a profit as a function of borrowing and firm characteristics. In addition, I include a set of eight regional dummy variables in this regression to help control for the impact of the socio-economic environment on earnings levels. In order to control for industry variations, I also include two-digit SIC industry dummy variables (Cole et al., 2004).

In the second stage, I estimate the probability that firm $i$ reports a small profit as a function of borrowing and firm characteristics, after controlling for the first stage probability of profitability. I follow this approach to ensure that the coefficients on my main variables of interest in the second regression reflect the relationship between these variables and loss avoidance, as opposed to profitability.

Specifically, in the first stage, I estimate the following equation by means of logistic regression:

$$
P\left(P_{i}=1\right)=\alpha_{0}+\alpha^{B} B_{O R R O W I N G}+\alpha^{F} F_{I R M_{i}}+\varepsilon_{i}
$$

Where:

POS $_{i}$

$=$ Indicator variable equal to 1 if firm is pretax margin $X$, defined as pretax income divided by sales, is positive;

BORROWING ${ }_{i} \quad=$ a vector of firm is borrowing characteristics, summarized in Panel $\mathrm{A}$ of Table 2.1;

FIRM

$=$ a vector of firm is characteristics, summarized in Panel $B$ of Table 2.1 , census region indicators and industry indicators;

and $\alpha^{B}$, and $\alpha^{F}$ are vectors of coefficients.

In the second stage, I estimate the following equation by means of logistic regression, using only the firms that have a pretax margin between -1 percent and +1 percent:

$$
\begin{aligned}
& P\left(\text { POS }_{i}=1 \mid X_{i} \in[-0.01,+0.01]\right)=\beta_{0}+\beta^{B} \text { BORROWING } \\
& i
\end{aligned}
$$

Where:

POS $_{i}$

$=$ Indicator variable equal to 1 if firm is pretax margin $X$, defined as pretax income divided by sales, is positive; 
$B O R R O W I N G_{i}$

$F I R M_{i}$

$P^{*}(\cdot)_{i}$
= a vector of firm is borrowing characteristics, summarized in Panel A of Table 2.1;

$=$ a vector of firm is characteristics, summarized in Panel B of Table 2.1;

$=$ The following transformation of the estimated probabilities in equation (2.1):

$$
P^{*}(\cdot)_{i}=\ln \left(\frac{P(\cdot)}{i} \frac{i}{1-P(\cdot)}{ }_{i}\right)
$$

and $\beta^{B}, \beta^{F}$ are vectors of coefficients.

The two-stage approach I follow is used to ensure that I measure loss avoidance, as opposed to profitability. Irrespective of the explanation for the relations between the borrowing characteristics and the likelihood of reporting a profit in the first stage, I want to make sure to control for these relations in the small interval between -1 and +1 percent profit margin. In this way I make sure that the effects I measure in the second stage explain firms' avoidance to report a small loss.

However, the two-stage approach I follow might induce econometric problems to the extent that the coefficient on the probability of profitability that 1 control for in the second stage is close to $1 .{ }^{10}$ To illustrate this, consider the following simplified two-stage approach:
(1) $y=a+b x+$ res 1
estimated for all firms
(2) $y=c+d x+e y^{*}+r e s 2$
estimated for firms reporting a profit margin between -1 and +1 percent

Now, in case $b$ is positive, there is an econometric explanation that $d$ will become negative. Just imagine that the observations used in the second stage show positive first stage residuals for low values of $x$ and negative first stage residuals for high values of $x$ (only in the small interval of $y \in[-1 \%,+1 \%]$ ). In other words, the residuals of the first stage regression are negatively correlated with the observations for $x$ in the second stage. To the extent that $e$ is close to 1 , the signs for $b$ and $d$ will then reverse between the first- and second stage (since the residuals of the first stage regression, i.e., $y-y^{*}$, are negatively correlated with the observations for $\mathrm{x}$ in the second stage). To rule out that my results are driven by this effect, I have estimated the second stage equation without controlling for $e^{*}$ (i.e., without controlling for the probability of profitability). The signs on the coefficients of this supplementary analysis (not tabulated) are equal to the signs

\footnotetext{
${ }^{10}$ I thank Martin Carree for pointing this out to me.
} 
of the coefficients reported here. This means that these potential specification errors should not affect my results.

\subsection{Descriptive analysis}

To compile my sample, I combine all data from the 1993 and 1998 version of the NSSBF. This original sample contains 8,198 observations. I omit 4,535 observations with missing data. The final sample has 3,663 observations of which 321 observations have a profit margin between -1 and +1 percent. ${ }^{11}$

Figure 2.1 shows the distribution of pretax profit margin with histogram interval widths of 1 percent ranging from -25 percent to +25 percent. Figure 2.1 illustrates firms' avoidance of reporting small losses. The histogram shows a bell-shaped distribution which is relatively smooth except in the area of a zero profit margin: a profit margin in the interval between 0 and -1 percent (109 observations) occurs less frequently than would be expected given the remainder of the distribution and a profit margin in the interval between 0 and +1 percent ( 212 observations) occurs much more frequently than would be expected. ${ }^{12}$

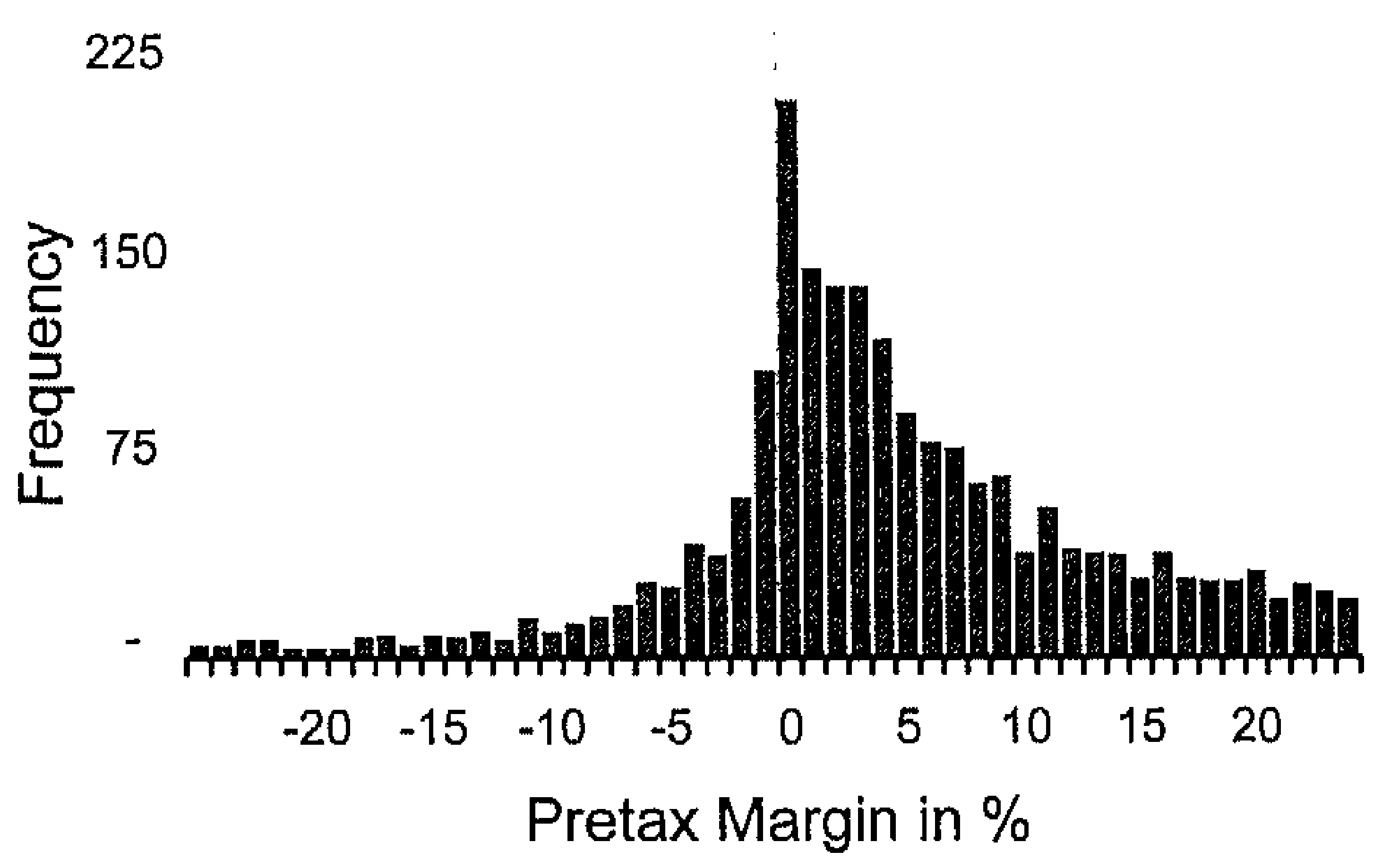

Figure 2.1 The distribution of pretax profit margin. The distribution interval widths are 1 percent and the location of zero on the horizontal axis is marked by the dashed line. The first interval to the right of zero contains all observations having a profit margin between 0 and +1 percent, the second interval contains all observations between +1 and +2 percent, and so on. Frequency is the number of observations in a given pretax margin interval.

\footnotetext{
${ }^{11}$ Consistent with prior studies, I remove observations for which profit margin is exactly zero since these observations are likely to be incorrect (see e.g., Burgstahler and Dichev, 1997, footnote 9). My conclusions remain similar, however, when I replicate my tests after including observations with zero profit margin.

${ }^{12}$ The subsample of firms with only C-corporations provides a similar picture.
} 
Table 2.1 identifies the independent variables used in my analyses, along with brief definitions. Table 2.2 presents means, medians and standard deviations for the 321 observations used in the second stage regression. The 321 firms having a profit margin between -1 and +1 percent are larger than the 3,663 firms included in the full sample. The mean and median assets for the 3,663 firms included in the full sample are $\$ 1,776,095$ and $\$ 146,808$, respectively, whereas the mean and median for the 321 firms with a small profit margin are $\$ 2,456,429$ and $\$ 473,456$, respectively. The 3,663 firms in the full sample are also slightly younger than the 321 firms with small margins. The former have a median age of approximately 12 years whereas the latter have a median age of 14 years.

Table 2.2 Descriptive statistics for 321 small businesses

\begin{tabular}{|c|c|c|c|c|c|}
\hline Variable & Mean & Median & $\begin{array}{l}\text { Standard } \\
\text { deviation }\end{array}$ & $\begin{array}{c}\text { First } \\
\text { quartile }\end{array}$ & Third quartile \\
\hline \multicolumn{6}{|c|}{ Panel A: Borrowing characteristics (BORROWING) } \\
\hline \multicolumn{6}{|l|}{ Reliance on debt capital } \\
\hline Line of credit: maximum amount & 0.077 & 0.018 & 0.169 & 0.000 & 0.090 \\
\hline Line of credit: untapped amount & 0.039 & 0.003 & 0.108 & 0.000 & 0.039 \\
\hline Reliance on short-term credit & -0.016 & -0.043 & 0.120 & -0.080 & 0.005 \\
\hline Additional equity amount & 0.006 & 0.000 & 0.032 & 0.000 & 0.000 \\
\hline \multicolumn{6}{|l|}{ Monitoring intensity } \\
\hline Concentration of loan obligations & 0.695 & 0.915 & 0.379 & 0.475 & 1.000 \\
\hline \multicolumn{6}{|l|}{ Relationship financing } \\
\hline $\begin{array}{l}\text { Fraction of total firm borrowing } \\
\text { from financia! institutions }\end{array}$ & 0.604 & 0.895 & 0.447 & 0.000 & 1.000 \\
\hline $\begin{array}{l}\text { Fraction of total firm borrowing } \\
\text { from non-financial firms }\end{array}$ & 0.028 & 0.000 & 0.136 & 0.000 & 0.000 \\
\hline $\begin{array}{l}\text { Fraction of total firm borrowing } \\
\text { from the owner and his family }\end{array}$ & 0.055 & 0.000 & 0.185 & 0.000 & 0.000 \\
\hline \multicolumn{6}{|c|}{ Panel B: Firm characteristics (FIRM) } \\
\hline \multicolumn{6}{|l|}{ Control variables } \\
\hline Presence of a loan obligation & 0.822 & 1.000 & 0.383 & 1.000 & 1.000 \\
\hline Total assets $(\$)$ & $2,456,429$ & 473,456 & $5,245,558$ & 98,000 & $2,268,746$ \\
\hline Firm age (years) & 17.523 & 14.000 & 13.624 & 9.000 & 24.000 \\
\hline Owner age (years) & 51.426 & 50.000 & 11.028 & 43.000 & 59.000 \\
\hline
\end{tabular}

Notes:

Variables are defined in Table 2.1

Both samples show fairly similar values for the firm's borrowing characteristics. First, the median size of the maximum amount that can be drawn on a firm's line of credit approaches 2 percent of sales. The median current liabilities establish almost 6 percent of sales. The average additional equity obtained during the most recent fiscal year is slightly more than 1 percent of the firm's sales for the full sample of 3,663 observations compared to 0.6 percent for the 321 observations with a small profit margin. 
THE RELIABILITY OF SMALL BUSINESSES' ACCOUNTING INFORMATION

Table 2.2 also reports information about the use of relationship financing. The median concentration of loan obligations of 0.9 indicates firms' and also borrowers' preference to develop one solid relation, i.e., to facilitate monitoring. The relationship financing variables show that most of the firms' outstanding loan obligations are provided by financial institutions. Non-financial firms and the owner (or his family) only marginally provide debt capital. However, descriptives indicate that a few firms are strongly dependent on debt provided by nonfinancial firms and the owner (or his family).

Table 2.3 presents the Pearson and Spearman correlations between the independent variables used in my analyses. Table 2.3 is based on the sample of 321 observations used in the second stage regression. Correlations in the sample of 3,663 observations used in the first stage are qualitatively similar. The variance inflation factors (not tabulated) do not indicate multicollinearity. The positive correlations between the presence of a loan obligation, the concentration of loan obligations and the fraction of total firm borrowing from financial institutions shows that firms using credit facilities tend to borrow from one creditor usually being a financial institution. Additionally, the positive correlation between the maximum amount that can be drawn on a firm's credit line and the amount that is still untapped shows that firms with higher untapped amounts also have more money at their disposal. Furthermore, $L N$ total assets is significantly positively correlated with most independent variables indicating that larger firms are older and more likely to have a loan obligation. Larger firms also have higher lines of credit, rely more on short-term credit and are more likely to concentrate their loan obligations with a single lender. Finally, the positive correlation between firm age and owner age shows that older firms have older owners. 


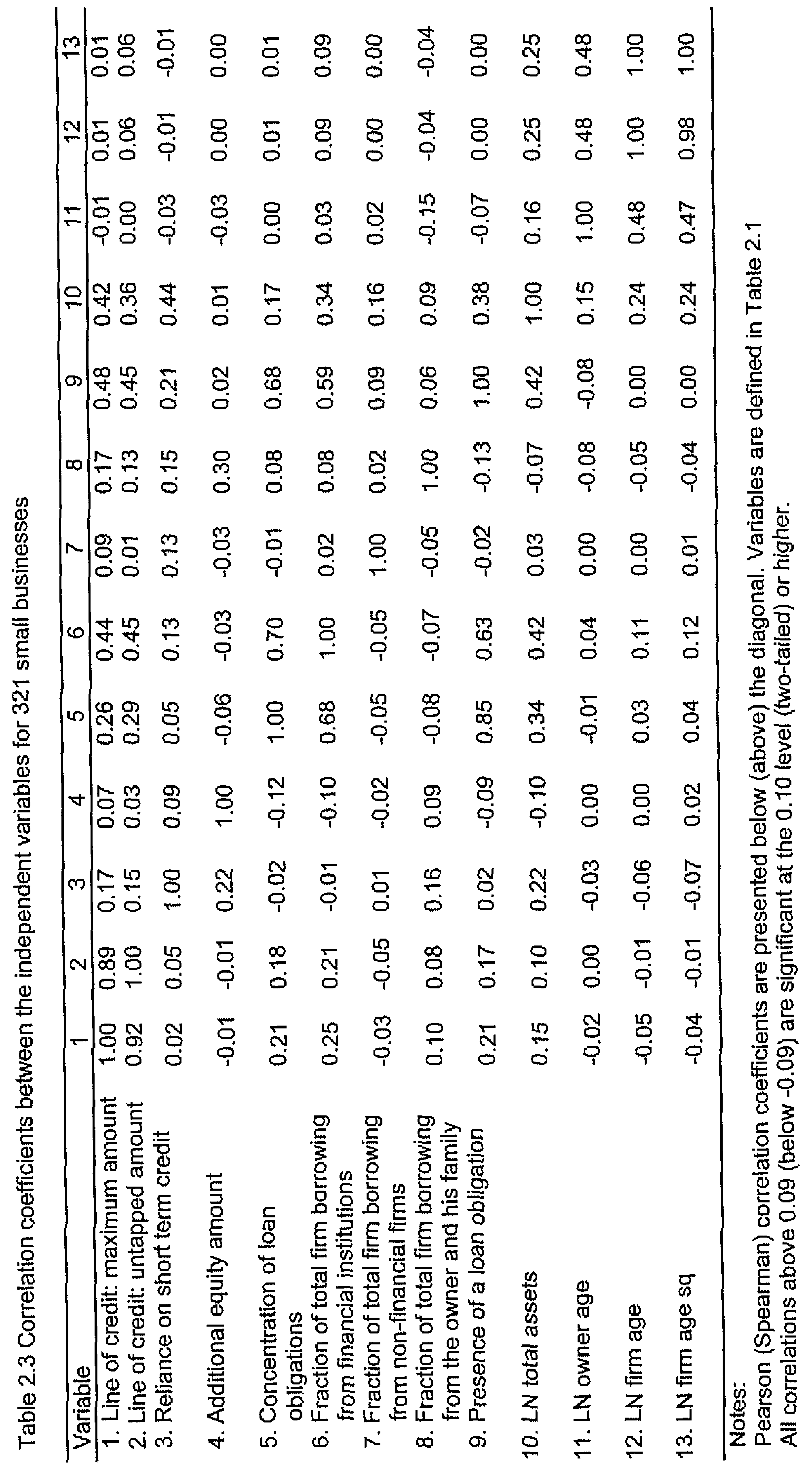




\section{$2.7 \quad$ Results}

Table 2.4 reports the results of my first logistic regression to estimate the probability that firm $i$ reports a profit (either large or small) as a function of borrowing and firm characteristics. The results indicate that the control variables, i.e., firm size, firm age, and firm type, are significant determinants of the probability of firm $i$ being profitable. The variable that I use to proxy for the lenders' monitoring intensity does not have a significant effect on profitability. Relationship financing, as measured by the fraction of borrowing from the firm's owner (and family members) or non-financial firms, and the reliance on debt capital are negatively related to profitability. 1 use the coefficients presented in Table 2.4 to estimate firm-specific probabilities that I use to control for the probability of profitability in my second logistic regression below.

Table 2.5 reports the logistic regression results for the differential likelihood of reporting a small profit versus a small loss after controlling for the probability that firm $i$ reports a profit. The analysis includes all 321 firms that report profit margins between -1 and +1 percent. The results provide support for the view that management's choice to avoid reporting a loss is positively associated with the firm's reliance on debt capital, confirming hypothesis 1.1 find that loss avoidance is negatively related to the relative size of the untapped portion of the firm's line of credit and positively to the relative size of the maximum amount that can be drawn on the firm's line of credit. Further, the amount of additional equity capital obtained by the firm and the amount by which a firm stretches its current liabilities are significantly positively related to the likelihood of reporting a small profit. Consistent with hypothesis 2 , which states that lenders' monitoring intensity negatively affects small businesses' loss avoidance, I find that the concentration of loan obligations among the firm's different lending partners is negatively related to the likelihood of reporting a small profit. Finally, the use of relationship financing does not have a significant effect on firm's reporting choices and the results thus provide no support for hypothesis 3 .

The last column of Table 2.5 reports the marginal probabilities, which I define as the change in the probability of loss avoidance due to a increase of 0.1 in one of the independent variables, while holding all other independent variables constant at their averages (cf. Greene, 2000, pp. 817-818). The calculated marginal probabilities indicate that the effects of the firm's reliance on debt capital and lenders' monitoring intensity on loss avoidance are of economically significant magnitudes. For example, an increase of 0.1 in the maximum amount of credit (which equals 59 percent of its standard deviation) increase the likelihood of loss avoidance with 5.1 percent, whereas an increase of 0.1 in the untapped portion of credit (93 percent of its standard deviation) decreases the 
likelihood of loss avoidance with 9.6 percent. Likewise, an increase of 0.1 in the concentration of loan obligations (26 percent of its standard deviation) decreases the likelihood of loss avoidance with 2.0 percent. The results in Table 2.5 further show that larger firms are significantly less likely to report a small profit. Firm age is initially negatively related to loss avoidance, but firms older than 14.8 years become more likely to avoid reporting losses. Table 2.5 finally shows that proprietorships and to a lesser extent $S$-corporations $(p=0.15)$ report less small profits than $\mathrm{C}$-corporations. These differences across organizational forms illustrate the difficulties of combining all data into just one sample.

Table 2.4 Logistic regression analysis of the relationship between profitability and BORROWING and FIRM characteristics $(N=3,663)$

$P\left(P O S_{i}=1\right)=\alpha_{0}+\alpha^{B}$ BORROWING $_{i}+\alpha^{F}$ FIRM $_{i}+\varepsilon_{i}$

\begin{tabular}{lc}
\hline Independent Variable & Coefficient Estimate \\
\hline Reliance on debt capital & \\
Line of credit: maximum amount & $-1.467^{* *}$ \\
Line of credit: untapped amount & $1.427^{* * *}$ \\
Reliance on short-term credit & $-0.682^{* * *}$ \\
Additional equity amount & $-3.287^{* * *}$ \\
Monitoring intensity & \\
Concentration of loan obligations & 0.046 \\
Relationship financing & \\
Fraction of total firm borrowing from financial institutions & 0.053 \\
Fraction of total firm borrowing from non-financial firms & $-0.548^{*}$ \\
Fraction of total firm borrowing from the owner and his family & -0.288 \\
Control variables & \\
Presence of a loan obligation & -0.015 \\
LN total assets & $0.121^{* * *}$ \\
LN owner age & $-0.715^{* * *}$ \\
LN firm age & $1.232^{* * *}$ \\
LN firm age sq & $-0.192^{* * *}$ \\
Financial records & 0.032 \\
Proprietorship & $0.905^{* * *}$ \\
Partnership & $0.486^{* *}$ \\
S-Corporation & $0.359^{* * *}$ \\
\hline Likelihood ratio & $247.58^{* * *}$ \\
\hline Notes: & \\
\hline
\end{tabular}

Notes:

Financial records $=$ Indicator variable that equals one if the firm had financial records available for preparing survey responses

Proprietorship = Indicator variable that equals one if the firm's organization type is sole proprietorship

Partnership = Indicator variable that equals one if the firm's organization type is partnership

$\mathrm{S}$-Corporation = Indicator variable that equals one if the firm's organization type is s-corporation

The remaining variables are as defined in Table 2.1. POS equals one for 2,983 observations, zero for 680 observations. In case a variable name starts with $L N \mid$ take the natural logarithm of that variable.

The regression analysis includes dummy variables for survey year, industry and census region.

Coefficients on these dummy variables are untabulated.

",$"$ denotes statistical significance at the $0.01,0.05$, and 0.10 level (two-tailed), respectively. 
THE RELIABILITY OF SMALL BUSINESSES' ACCOUNTING INFORMATION

Table 2.5 Logistic regression analysis of the relationship between reporting small profits (loss avoidance) and BORROWING and FIRM characteristics ( $N=321$ )

$$
\begin{aligned}
P\left(P_{i}=1 \mid X_{i} \in[-0.01,+0.01]\right) & =\beta_{0}+\beta^{B} \text { BORROWING }_{i}+\beta^{F} \text { FIRM }_{i}+ \\
& \beta^{P} P^{*}\left(\text { POS }_{i}=1 \mid \text { BORROWING }_{i}, \text { FIRM }_{i}\right)_{i}+\eta_{i}
\end{aligned}
$$

\begin{tabular}{|c|c|c|c|}
\hline Independent Variable & $\begin{array}{l}\text { Expected } \\
\text { sign }\end{array}$ & $\begin{array}{l}\text { Coefficient } \\
\text { Estimate }\end{array}$ & $\begin{array}{l}\text { Marginal } \\
\text { Probability }\end{array}$ \\
\hline \multicolumn{4}{|l|}{ Reliance on debt capital } \\
\hline Line of credit: maximum amount & + & $2.601^{*}$ & 0.051 \\
\hline Line of credit: untapped amount & - & $-4.273^{*}$ & -0.096 \\
\hline Reliance on short-term credit & + & $3.631^{* *}$ & 0.070 \\
\hline Additional equity amount & + & $12.585^{\circ}$ & 0.189 \\
\hline \multicolumn{4}{|l|}{ Monitoring intensity } \\
\hline Concentration of loan obligations & - & $-0.920^{*}$ & -0.020 \\
\hline \multicolumn{4}{|l|}{ Relationship financing } \\
\hline $\begin{array}{l}\text { Fraction of total firm borrowing from financial } \\
\text { institutions }\end{array}$ & + & 0.245 & 0.005 \\
\hline $\begin{array}{l}\text { Fraction of total firm borrowing from non-financial } \\
\text { firms }\end{array}$ & - & -1.130 & -0.024 \\
\hline $\begin{array}{l}\text { Fraction of total firm borrowing from the owner and } \\
\text { his family }\end{array}$ & - & 0.268 & 0.006 \\
\hline \multicolumn{4}{|l|}{ Control variables } \\
\hline Presence of a loan obligation & + & 0.820 & 0.017 \\
\hline LN total assets & $?$ & $-0.162^{*}$ & -0.003 \\
\hline LN owner age & $?$ & 0.872 & 0.018 \\
\hline LN firm age & $?$ & $-2.546^{* n}$ & -0.056 \\
\hline LN firm age sq & $?$ & $0.473^{k *}$ & 0.010 \\
\hline Financial records & $?$ & 0.190 & - \\
\hline Proprietorship & $?$ & $-1.290^{n *}$ & - \\
\hline Partnership & $?$ & -0.891 & - \\
\hline S-Corporation & $?$ & -0.469 & - \\
\hline Estimated probability of profitability & + & $1.380^{* * *}$ & 0.028 \\
\hline Likelihood ratio & & $27.16^{*}$ & \\
\hline
\end{tabular}

$=$ The following transformation of the estimated probabilities in Table 2.4:

Estimated probability of profitability

$$
P^{*}()_{i}=\ln \left(\begin{array}{c}
P(\cdot) \\
\frac{i}{1-P(\cdot)} \\
i
\end{array}\right)
$$

The remaining variables are as defined in Table 2.1. POS equals one for 212 observations, zero for 109 observations. In case a variable name starts with LN I take the natural logarithm of that variable. The regression analysis includes a dummy variable for survey year. The coefficient on this dummy variable is untabulated. The column containing the marginal probability reports the partial derivatives of probabilities with respect to the vector of independent variables $x$, which I define as the change in the probability of loss avoidance after a change in $x_{i}$ of 0.1 , computed at the means of vector $x$ (cf. Greene, 2000, pp. 817-818).

"."." denotes statistical significance at the $0.01,0.05$, and 0.10 level, respectively. Statistical tests are one-tailed when I have expectations about the direction of the relationship, two-tailed otherwise. 
Table 2.6 Logistic regression analysis of the relationship between reporting small profits (loss avoidance) and BORROWING and FIRM characteristics using a sample of $\mathrm{C}$-corporations only ( $\mathrm{N}=201)$

$$
\begin{aligned}
P\left(P_{i}=1 \mid X_{i} \in[-0.01,+0.01]\right)=\beta_{0}+\beta^{B} \text { BORROWING }_{i}+\beta^{F} \text { FIRM }_{i}+ \\
\beta^{P} P^{*}\left(\text { POS }_{i}=1 \mid \text { BORROWING }_{i}, \text { FIRM }_{i}\right)_{i}+\eta_{i}
\end{aligned}
$$

\begin{tabular}{|c|c|c|c|}
\hline Independent Variable & $\begin{array}{l}\text { Expected } \\
\text { sign }\end{array}$ & $\begin{array}{l}\text { Coefficient } \\
\text { Estimate }\end{array}$ & $\begin{array}{l}\text { Marginal } \\
\text { Probability }\end{array}$ \\
\hline \multicolumn{4}{|l|}{ Reliance on debt capital } \\
\hline Line of credit: maximum amount & + & $5.342^{* *}$ & 0.087 \\
\hline Line of credit: untapped amount & - & $-11.483^{* *}$ & -0.263 \\
\hline Reliance on short-term credit & + & $2.570^{*}$ & 0.045 \\
\hline Additional equity amount & + & -15.194 & -0.354 \\
\hline \multicolumn{4}{|l|}{ Monitoring intensity } \\
\hline Concentration of loan obligations & - & $-1.900^{* *}$ & -0.037 \\
\hline \multicolumn{4}{|l|}{ Relationship financing } \\
\hline $\begin{array}{l}\text { Fraction of total firm borrowing from financial } \\
\text { institutions }\end{array}$ & + & $0.911^{*}$ & 0.017 \\
\hline $\begin{array}{l}\text { Fraction of total firm borrowing from non-financial } \\
\text { firms }\end{array}$ & - & $-2.970^{* *}$ & -0.060 \\
\hline $\begin{array}{l}\text { Fraction of total firm borrowing from the owner and his } \\
\text { family }\end{array}$ & - & 0.708 & 0.013 \\
\hline \multicolumn{4}{|l|}{ Control variables } \\
\hline Presence of a loan obligation & + & $1.419^{\prime \prime}$ & 0.026 \\
\hline LN total assets & $?$ & -0.068 & -0.001 \\
\hline LN owner age & $?$ & 0.561 & 0.010 \\
\hline LN firm age & $?$ & -0.510 & -0.010 \\
\hline LN firm age sq & $?$ & 0.120 & 0.002 \\
\hline Financial records & $?$ & -0.225 & - \\
\hline Estimated probability of profitability & + & $0.863^{* *}$ & 0.016 \\
\hline Likelihood ratio & & $25.90^{*}$ & \\
\hline
\end{tabular}

Notes:

Estimated probability of $\quad=$ The following transformation of the estimated probabilities in Table 2.4: profitability

$$
P^{*}(\cdot)_{i}=\ln \left(\begin{array}{c}
P(\cdot) \\
\frac{i}{1-P(\cdot)} \\
i
\end{array}\right)
$$

The remaining variables are as defined in Table 2.1. POS equals one for 133 observations, zero for 68 observations. In case a variable name starts with LN I take the natural logarithm of that variable. The regression analysis includes a dummy variable for survey year. The coefficient on this dummy variable is untabulated. The column containing the marginal probability reports the partial derivatives of probabilities with respect to the vector of independent variables $x$, which I define as the change in the probability of loss avoidance after a change in $x_{i}$ of 0.1 , computed at the means of vector $x$ (cf. Greene, 2000, pp. 817-818).

******** denotes statistical significance at the $0.01,0.05$, and 0.10 level, respectively. Statistical tests are one-tailed when I have expectations about the direction of the relationship, two-tailed otherwise.

As indicated before, Ang et al. (2000) argue that proprietorships often do not distinguish between personal and business funds. In addition, partnerships and S-corporations are not subject to corporate taxation. Consequently, to strengthen my test and avoid complications of comparing profit margins across organizational forms, I re-estimate the logistic model using a sample of only C- 
corporations. This subsample consists of 201 observations, and the descriptive statistics (untabulated) are similar to those presented in Table 2.2. ${ }^{13}$ Table 2.6 presents the results of this analysis.

The results of my second analysis (of C-corporations only) lead to similar inferences as those of my initial analysis (of all organization types), with two notable exceptions. First, for the subsample of C-corporations, I find evidence consistent with Hypothesis 3 that the use of relationship financing reduces the firm's incentive to avoid losses. Both the fraction of borrowing from financial institutions and the fraction of borrowing from non-financial firms are significantly related to the likelihood of reporting a small profit and in the expected direction (positive and negative respectively). Second, the last column of Table 2.6, which reports the marginal probabilities, not only confirms the economic significance of the effects of the borrowing characteristics on loss avoidance, but also shows that the economic impact is greater for $\mathrm{C}$-corporations compared to other organizational forms.

Overall, the results presented in Table 2.5 and 2.6 provide support for my prediction that management's choice to avoid reporting a loss is negatively associated with the existence of relationship financing as well as with the monitoring intensity of the firm's lenders, and positively associated with the firm's reliance on debt capital.

\subsection{Summary and conclusion}

Lenders to small businesses are keenly interested in reliable accounting information to determine the financial strength of the borrower. Since small businesses often lack a publicly available track record, their self-supplied information, such as accounting information, is of great importance in their transactions with lenders. Given the potential conflicts of interests that exist between small businesses' owner-managers and outside suppliers of capital and in the absence of third-party auditing, the question arises how reliable such self-supplied information is.

Following the transactions costs theory, I expect that firms have an incentive to misreport earnings since potential and existing lenders are likely to offer better terms of transactions if they perceive the firm to be less likely to default or delay loan payments. My focus on manager-owned firms allows me to abstract from the influence of information asymmetry between owner and manager and capital market pressures on firms' reporting decisions. I provide evidence that small businesses' earnings management, and more specifically, loss avoidance, is

\footnotetext{
${ }^{13}$ The only significant difference is that $\mathrm{C}$-corporations and their owners are, on average, older than non-C-corporations and their owners ( $p<0.10$ for both variables).
} 
related to firm characteristics as well as borrowing characteristics, which determine lenders' reliance on simple earnings-based heuristics. Specifically, I find that loss avoidance is positively related to small businesses' reliance on debt capital and negatively related to small businesses' use of relationship financing and their lenders' monitoring intensity.

As with any empirical study, my study has its limitations. First, as argued, my dataset allows me to investigate one important manifestation of earnings management, i.e., loss avoidance, but prevents me from examining firms' financial reporting decisions in detail. To the best of my knowledge, a dataset that contains both detailed multi-year financial statement data and comprehensive information about private firms' lending relationships is not yet available. Future research may focus on analyzing private firms' accounting decisions in more detail when such an opportunity presents itself. Second, an implicit assumption of my analysis is that the earnings number that the firms supplied to the NSSBF is the same number that they present to their lenders. Although I have no good reason to believe that this assumption is unjustified, a limitation of my study remains that I cannot test this assumption.

I contribute to the literature by providing insight into the reliability of small businesses' accounting information in lending transactions. My data come from two surveys that were held during the 1990s. During the past decade, the credit application process has gone through some changes. For instance, Petersen and Rajan (2002) argue that loan officers would traditionally make a credit decision based on the application material from the borrower as well as interviews with the borrower and references. This very labor intensive process is gradually substituted with credit scoring models, analytic decision rules and computerized credit reports. As a result, the traditional spectrum of "soft" information obtained from close contact between the loan officer and the borrower is decreasing in importance. Petersen and Rajan (2002) demonstrate that new technology provides more timely hard information about the creditworthiness of the borrower and thereby changes the nature of small business lending. A firm's financial reports are a decisive source of hard information. I expect that a change in the credit granting and monitoring process as characterized by Petersen and Rajan (2002) is likely to further increase the use of accounting information, which strengthens the importance of my findings. 


\section{Chapter 3}

\section{The relation between CEO equity incentives and performance measures in CEO annual bonus contracts}

\subsection{Introduction}

In this chapter I examine to what extent the use of stock price as a performance measure in CEO compensation is linked to the use of performance measures other than price. ${ }^{14}$ Price-based performance measures align the incentives of executives with the interests of shareholders and promote managerial risk taking, but have at least two limitations. First, these measures also expose managers to market-wide changes in equity values. Second, they do not specify in what project area risks should be taken. This study contributes to the literature by showing that non-price performance measures in CEO annual bonus contracts are used to address these limitations of price-based performance measures. That is, I hypothesize that non-price performance measures in CEO annual bonus contracts are used as a risk management device to shield CEOs from macroeconomic risk as well as to encourage CEOs to take risks in a particular area desired by shareholders.

To test my hypothesis, I examine the effect of CEOs price-based incentives-as captured by the volatility and price sensitivities of managerial equity portfolio holdings-on the reliance on alternative non-price performance measures in CEO annual bonus contracts. The sensitivity of managers' wealth to stock price induces managers to take actions that lead to sustainable, long-run value creation. However, increases in the sensitivity of managers' wealth to stock price simultaneously increase managers' exposure to market-wide movements in equity value. I hypothesize that boards include accounting information in annual bonus contracts to shield executives from these industry-specific and

\footnotetext{
${ }^{14}$ As indicated in chapter 1, I distinguish two categories of non-price performance measures: accounting vs. non-accounting.
} 
economy-wide stock price shocks that are beyond the executives' control. That is, since accounting measures such as earnings are more sensitive to firmspecific than market-wide risk, I argue that these measures are used in CEO annual bonus contracts to reduce the macroeconomic risk imposed on CEOs by equity incentives. The choice for accounting measures over other performance measures that are more sensitive to firm-specific than market-wide risk is driven by the idea that accounting information is understandable, conservative, quantitative and verifiable by third parties. Furthermore, accounting measures such as earnings are highly aggregated, reflecting the sum of all managerial actions. In addition, the costs of collecting and processing information from the accounting system are low relative to alternative contracting measures, since accounting information is already available for other purposes. Finally, the use of accounting information as performance measure ensures that CEOs keep track of shortterm operational performance, also in the presence of long-term equity incentives.

In addition to the risk reducing role of non-price performance measures when managers' wealth is sensitive to stock price, I expect that non-price performance measures have a risk steering role when managers' wealth is sensitive to stock return volatility. The sensitivity of managers' wealth to stock return volatility induces managers to take more risk and invest in risk-increasing, positive NPV projects. However, the sensitivity of managers' wealth to stock return volatility does not specify the direction of managerial action. That is, the sensitivity to stock return volatility remains silent on the specific risk that shareholders want managers to take. As a consequence, I expect firms to use more immediate performance information such as non-accounting measures to overcome this shortcoming and motivate managerial actions along those risk areas desired by shareholders. This means that non-accounting measures (e.g., strategic objectives or new product development measures) in the annual bonus contract signal those risky positive NPV projects that shareholders do not want to forego. Therefore, I test whether the sensitivity of managers' wealth to stock return volatility is positively associated with the use of non-accounting measures in CEO annual bonus contracts.

My sample consists of 269 firms (997 firm-years) that provide detailed information in their proxy statements on the performance measures used in their annual bonus contracts over the period 1998-2002. Following prior research (e.g., Ittner et al., 1997), I focus on formal compensation contracts where the relative weights placed on accounting and non-accounting performance measures are known to the CEO and disclosed in the proxy statement on an ex ante basis. I am able to identify a subset of 56 firms (184 firm-years) that assign nonzero weights to non-accounting measures in their annual bonus contract. 
Consistent with my first hypothesis, I find a positive relation between the sensitivity of managers' wealth to price and the reliance on accounting performance measures. This result shows that when CEOs' exposure to macroeconomic risk increases, compensation contracts make more use of accounting performance measures in CEO annual bonus contracts to shield CEOs from such risks. I also find evidence in support of my second hypothesis, which states that the sensitivity of managers' wealth to stock return volatility is positively associated with the use of non-accounting measures in annual bonus contracts. This finding indicates that firms that provide managers with incentives to invest in risky projects also use non-accounting measures that ensure risk taking in those areas desired by shareholders.

In my analyses, I control for several potential economic determinants of the reliance on accounting and non-accounting performance measures in CEO annual bonus contracts (see e.g., Bushman et al., 1996; Ittner et al., 1997; Said et al., 2003). Consistent with prior literature, I find that the reliance on nonaccounting measures in CEO annual bonus contracts varies with the firm's organizational strategy, the length of product development cycles, and the exogenous noise in a firm's accounting performance measures.

I contribute to the literature in the following ways. First, by showing that firms use non-price performance measures as a risk management device, I provide evidence that it is the portfolio of price and non-price performance measures used in CEO compensation contracts that matters to CEOs. This enhances our knowledge of the interrelation between alternative performance measures in CEO compensation contracts and is important for a better understanding of observed compensation contract designs. Second, I use more comprehensive measures of equity incentives than prior research on the determinants of accounting and other non-price performance measures in CEO annual bonus contracts. Because 1 use separate estimates of the sensitivity of manager's equity portfolio holdings to stock price and to stock return volatility, I can show that different types of non-price performance measures address different kinds of risk-related problems. More specifically, I find that accounting measures are used to reduce risk from equity-based pay whereas non-accounting measures steer risky decision making in the direction desired by shareholders.

The remainder of this chapter is organized as follows. In section 3.2, I develop my research hypotheses. In sections 3.3-3.5 I discuss my sample, my empirical models and I define the measurement of my compensation and control variables. In section $3.6,1$ provide descriptive statistics. In section 3.7 , I present the results of the empirical tests, and conclude in section 3.8. 


\subsection{Theory and hypotheses}

Agency theory shows that executive compensation contracts are a tool to align managerial actions with shareholder's interests. Since shareholder's wealth is directly affected by the stock price, the shareholder's interests seem perfectly aligned with the interests of management if the manager is paid with the firm's securities. Consistent with this, there is considerable evidence that increases in equity ownership result in subsequent improvements in firm performance (e.g., Core and Larcker, 2002; Hanlon et al., 2003). However, the value of the firm's shares is not the same as the value of the manager's contribution to the firm (Paul, 1992; Feltham and Xie, 1994).

Although stock price is a forward-looking and informative measure of managerial action, stock prices are affected by industry and market effects. As a result, firms using stock price as a performance measure expose managers to wealth fluctuations beyond their control. Additionally, while stock-based pay helps to overcome managers' natural aversion to risk (Hall, 2003), it does not specify the direction of managerial action to specific risks. Therefore, stock price alone is unlikely to yield an optimal compensation contract. I show how these shortcomings of equity-based pay leaves room for other performance measures to improve contracting.

Lambert et al. (1991) indicate that the value of a compensation contract depends on the portfolio of incentives provided by different components in the contract. Different contract components are simultaneously designed to establish the optimal level of portfolio incentives. This implies that studies on the use of alternative performance measures in CEO compensation contracts have to consider the portfolio of performance measures in the contract. I therefore distinguish between price and non-price-based performance measures in CEO compensation contracts.

As indicated, price-based measures directly link changes in shareholder wealth to changes in executive wealth, and thereby contribute to the reduction of agency problems. An increase in the sensitivity of managers' wealth to stock price (i.e. an increase in the slope of the relation between stock price and managers' wealth; hereafter also referred to as sensitivity to price) induces managers to take actions that increase equity value. Since stock prices are forwardlooking, this means that increases in the sensitivity to price, encourage sustainable or long-run value creation. There is, however, also a downside to an increase in the sensitivity to price. Because stock prices incorporate factors that are beyond managers' control, an increase in the sensitivity to price simultaneously increases the manager's exposure to market-wide stock price movements. Relative performance evaluation (RPE) provides a potential solution to this problem, since relative performance-based contracts remove the shock term that 
affects both the stock price of the firm and its peer group (e.g., Gibbons and Murphy, 1990). However, there is little evidence on the use of RPE in CEO compensation contracts (e.g., Murphy, 1999). In the first place, not using RPE, and thus paying with market movements helps retain executives, since it ensures reservation wage payments (e.g., Rajgopal et al., 2006). Second, the absence of RPE reflects the various costs associated with its use (e.g., Gibbons and Murphy, 1990; Lambert, 2001). For example, rewards based on relative performance generate incentives for executives to abandon lines of business with fierce competition, even if these lines of business yield good performance in absolute terms. Additionally, RPE reduces incentives to deal with common risks that are relevant to the firm's shareholders, but filtered out of the contract. Furthermore, RPE payouts are controversial to shareholders if their firm's stock price plunges, even if this plunge is larger for peer firms. As a result, firms must use other, more cost effective, mechanisms to deal with the uncontrollable market-wide movements in equity values.

I hypothesize that firms use readily available non-price performance measures to protect CEOs from events beyond their control. Sloan (1993) indicates that accounting information, such as earnings, helps shield executives from market-wide risks in equity values. In addition to this, accounting information is understandable, conservative, quantitative and verifiable by third parties. Furthermore, accounting measures such as earnings are highly aggregated, which ensures that they capture the effect of all managerial actions. Moreover, since accounting information is already available for other purposes, the costs of collecting and processing information from the accounting system are low relative to alternative contracting measures. Finally, accounting measures are useful to safeguard short-term operational performance of the firm. Thus, while stock prices are forward-looking and align the long-run objectives of shareholders and managers, accounting measures are the most efficient and cost effective performance measures to ensure short-term operational performance and to shield CEOs from macroeconomic risk. This yields the following hypothesis:

H1: The sensitivity of CEO stock and stock option portfolio holdings to stock price is positively associated with the reliance on accounting performance measures in CEO annual bonus contracts.

In addition to the sensitivity to price, firms can manage the sensitivity of CEOs' wealth to the volatility of firm value (hereafter also referred to as sensitivity to volatility or convexity) to provide risk taking incentives. While this reduces the likelihood that managers bypass valuable risky projects, it does not specify the specific risks that shareholders would like managers to take. To overcome this limitation of simply varying the sensitivity to volatility, I hypothesize that firms 
incorporate non-price measures to encourage managerial actions along those risk dimensions that shareholders prefer. Thus, while sensitivity to volatility is necessary to induce managers to invest in risky, positive NPV projects, additional non-price performance measures will steer risk taking towards specific risk areas. Examples of such risk areas are innovation, quality initiatives, or strategic goals. Since accounting measures are unlikely to fully incorporate all relevant information about CEOS' decisions in these risk areas, I expect that the reliance on non-accounting measures that are informative about these risks is positively related to sensitivity to volatility. For example, shareholders' desire to innovate will better be met by the use of non-accounting measures related to new product development than by the use of accounting earnings (Höppe, 2008). Since Guay (1999) demonstrates that the sensitivity to volatility in managers' incentive schemes is mainly driven by stock options, I test the following hypothesis:

$\mathrm{H} 2$ : The sensitivity of CEO stock option portfolio holdings to stock return volatility is positively associated with the reliance on non-accounting performance measures in CEO annual bonus contracts.

\subsection{Data}

The data analyzed in this study come from four sources. CEO compensation data comes from the Standard and Poor's ExecuComp database, accounting data from the Standard and Poor's Compustat database, price data from Datastream, and performance measure data from firms' proxy statements.

My initial sample consists of all firms in ExecuComp without CEO turnover during the period 1998-2002, a period that includes both bull and bear markets. Following previous studies (e.g., Ittner et al., 1997; Said et al., 2003), I use proxy data (DEF 14a) from the EDGAR system ${ }^{15}$ to create a sample of firms where the explicit weights placed on accounting and non-accounting performance measures in the CEO annual bonus contract are known to the CEO and disclosed on an ex ante basis. To identify firms that use explicit weights, I read the CEO compensation paragraph of each proxy statement, searching for keywords such as "weight", "exclusively", "solely" and "entirely". To identify the use of nonaccounting measures I search for keywords such as "customer satisfaction," "quality," "process improvement," "reengineering," "new product development," "diversity," "market share," "productivity or efficiency," "safety," "innovation," "operational measure or operational performance," and "strategic objectives." I classify performance measures such as "earnings per share," "revenue," "return

15 EDGAR data can be found at the following website: http://www.sec.gov/edgar/searchedgar/companysearch.html. 
on assets", and "return on sales" as accounting performance measures. These selection criteria result in a final sample of 997 firm-year observations (269 firms). Below, I describe how I operationalize my variables.

\section{$3.4 \quad$ Measures}

\subsubsection{Definition of CEO equity incentive measures and the use of non- accounting measures}

As argued, I expect that the volatility and price sensitivities of managerial equity portfolios affect the reliance on alternative performance measures in the CEO's annual bonus contract. Following Core and Guay (1999), I measure the equity portfolio sensitivity to price as the dollar change (in $\$$ thousands) in the value of the CEO's stock and option portfolio holdings for a 1\% change in the stock price. Consistent with Knopf et al. (2002) I use the logarithmic transformation of the sensitivity to price measure in my tests. The option portfolio holdings' sensitivity to stock return volatility is calculated as the natural logarithm of the dollar change (in $\$$ thousands) in the value of the CEO's option portfolio holdings resulting from a $1 \%$ change in the annualized standard deviation of the firm's stock return (Core and Guay, 1999). Given that the total sensitivity of common stock value to stock return volatility is very small for most CEOs (Guay, 1999), I only include the CEO's option portfolio holdings in my estimate for the sensitivity of the CEO's wealth to equity risk. ${ }^{16}$

I employ three different variables to measure the use and incentive-intensity of non-accounting performance measures in the CEO's annual bonus contract. First, I create an indicator variable (NAM) taking on the value of 1 if the firm uses non-accounting performance measures in the CEO's annual bonus contract. Second, I use the relative weight placed on non-accounting performance measures (PERFMEAS) in the CEO's annual bonus contract, where the weights on accounting and non-accounting measures sum to 100 percent. Of the 997 firmyears in the sample, 184 employ non-accounting measures in evaluating CEO performance. The mean weight placed on non-accounting performance is $7.9 \%$ across all 997 firm-year observations and $42.8 \%$ in the 184 firm-year observations with non-zero weights on non-accounting measures (not tabulated). Third, I compute an additional measure that captures the amount of compensation that is affected by performance on non-accounting performance measures. Bushman et al. (1996) and Ittner et al. (1997) argue that the amount of compensation that is at-risk based on non-accounting measures depends not only on the relative

\footnotetext{
${ }^{16}$ Appendix A describes the option valuation model and sensitivities of individual options to stock price and stock return volatility in detail.
} 
weight placed on these measures, but also on the target bonus amount. This measure is a more comprehensive proxy of the importance of non-accounting information to the board in making both compensation and governance decisions. ${ }^{17}$ Consistent with Ittner et al. (1997), I compute this variable as the percentage of the target bonus amount subject to non-accounting performance to target cash compensation,

$N F C O M P=\left(\frac{T A R G E T \text { BONUS }}{\text { BASE SALARY }+ \text { TARGET BONUS }}\right) *$ PERFMEAS

The mean value for NFCOMP equals $3.5 \%$ in the total sample and $19.2 \%$ in the subsample of firms placing non-zero weights on non-accounting performance (not tabulated)..$^{18}$

\subsubsection{Control variables}

To control for firm characteristics that may affect the choice of performance measures in annual bonus contracts I include a number of additional factors. I use the probability of bankruptcy measured by Altman's Z-score to control for a firm's financial health (Altman, 1968). Following Ittner et al. (1997) and Said et al. (2003), I expect that distressed firms place less weight on non-accounting measures in the annual bonus contract.

I use three variables as indicators for the firm's organizational strategy: (1) the ratio of market value to book value, (2) the ratio of research and development to sales, and (3) sales growth (cf. Said et al. 2003). ${ }^{19}$ Like Ittner et al. (1997) and Said et al. (2003), I expect that innovative firms (i.e. firms with higher scores for the Strategy measure) are more likely to make use of non-accounting

\footnotetext{
17 Höppe and Moers (2007) provide empirical evidence consistent with the argument that bonus contracts communicate the way in which boards of directors evaluate the CEO and that these evaluations are subsequently used in governance decisions such as CEO termination.

${ }^{18}$ Proxy statements did not provide target bonus amounts for all the firms in the sample. I follow Ittner et al. (1997) to assign target bonus values to these firms. In those instances in which minimum and maximum bonuses were given in the proxy, the average of the minimum and maximum was used as the target. If only the maximum was provided, the target was defined as half the maximum bonus. For the remaining firms, I imputed the target bonus by first regressing the available target bonus amounts on industry indicators and firm sales. The coefficients from this model were then used to impute the missing bonus targets. This imputation was used for 54 percent of the sample (compared to 39 percent reported by Ittner et al. (1997)).

${ }^{19}$ For cases where research and development was missing, I imputed a value of zero for this variable. This imputation was used for $46 \%$ of the sample. Eliminating observations with missing values for research and development is undesirable because it biases the sample in favour of R\&D-intensive firms.
} 
measures. In addition to the effect of organizational strategy, I predict that firms with longer product development and product life cycles are more likely to rely on non-accounting performance measures. I categorize the product time horizon of my firms according to the industry group classification scheme from the National Academy of Engineering (1992). ${ }^{20}$

I use the standard deviation of stock returns as a proxy for environmental uncertainty. Previous studies (e.g., Demsetz and Lehn, 1985; Core and Guay, 1999; Ittner et al., 2003) predict a positive association between this variable and the level of equity incentives. To the extent that some of the dimensions of managerial performance caused by a higher concentration of ownership are also captured by non-accounting performance measures, I expect firms operating in noisier environments to make more use of non-accounting measures. In addition, following Ittner et al. (1997), I measure the exogenous noise in accounting performance measures as the time-series variability in median industry accounting returns over the three years prior to the proxy data (Industry level exogenous noise). The use of non-accounting measures is assumed to be positively related to the variance in industry financial accounting measures. Similar in spirit to the approach by Bushman et al. (1996), Ittner et al (1997) and Said et al. (2003), I consider the time-series correlation between accounting returns and stock returns as an inverse proxy for the noise in accounting measures (Firm level exogenous noise). I expect firms with a high correlation to rely less on nonaccounting measures.

Consistent with Ittner et al. (1997) and Core et al. (1999), I use multiple variables to examine the effect of CEO influence on the use of non-accounting performance measures in CEO bonus contracts. ${ }^{21}$ Since there is mixed evidence as to whether powerful CEOs use non-accounting performance measures to manipulate the payments obtained from the annual bonus contract I make no prediction for the sign of the coefficient of this variable.

I finally control for firm size, measured as the logarithm of the firm's sales and include two-digit SIC industry dummy variables (Cole et al., 2004) and year indicator variables. Table 3.1 summarizes my variable definitions.

\footnotetext{
${ }^{20}$ If a firm's industry product development cycle is less than or equal to four years, the firm is classified as having a short product development cycle. If a firm's industry product development cycle is greater than four years, the firm is classified as having a long product development cycle. A similar procedure is used to classify product life cycles.

${ }^{21}$ I use four indicators for CEO influence: (1) proportion of external board members appointed after CEO appointment, (2) proportion of internal board members appointed after CEO appointment, (3) CEO shares divided by the number of outstanding shares owned by external board members, (4) Log(CEO tenure). Higher CEO influence scores reflect more influence of the CEO over the board of directors.
} 
CHAPTER 3

Table 3.1 Variable definitions

\begin{tabular}{ll}
\hline Variable name & Variable description \\
\hline PERFMEAS & $\begin{array}{l}\text { The relative weights placed on non-accounting performance meas- } \\
\text { ures in CEO annual bonus contracts. } \\
\text { The percentage of short-term compensation based on non-accounting } \\
\text { performance measures in CEO annual bonus contracts. } \\
\text { NFCOMP = (Target Bonus)/(Salary + Target Bonus) }\end{array}$ PERFMEAS \\
NFCOMP & $\begin{array}{l}\text { Indicator variable takes on the value of one if the firm uses non- } \\
\text { accounting performance measures with specific weights and zero if it } \\
\text { uses accounting measures alone. }\end{array}$ \\
NAM & $\begin{array}{l}\text { The change in the dollar value of the CEO's stock and option holdings } \\
\text { for a 1\% change in the stock price. }\end{array}$ \\
Sensitivity to price & $\begin{array}{l}\text { The change in the dollar value of the CEO's option holdings for a 1\% } \\
\text { change in the stock return volatility. }\end{array}$ \\
Sensitivity to volatility & Altman's z-score, as represented by the Compustat variable \\
Financial health & ZSCORE. \\
Indicators for Strategy &
\end{tabular}

Ratio of research and development expenditures to sales based on an Research \& development to average of the three consecutive years preceding the proxy data. For sales cases where research and development spending was missing, I imputed a value of zero for this variable.

Market-to-book

Ratio of the market value of common stock to book value of stockholders' equity based on an average of the three consecutive years preceding the proxy data.

Sales growth

Growth in sales in the year prior to the proxy data.

Indicator variable equal to one if a firm has a long product life cycle (its industry product life cycle is greater than four years in the National Academy of Engineering scheme), and zero otherwise in the year prior to the proxy data.

Indicator variable equal to one if a firm has a long product development cycle (its industry product development cycle is greater than four years in the National Academy of Engineering scheme), and zero otherwise in the year prior to the proxy data.

Product development cycle

Standard deviation of monthly stock market returns over the three

Standard deviation of stock returns years prior to the proxy data.

Indicators for industry level exogenous noise

Standard deviation of median ROA/ROE/ROS

Standard deviations of accounting returns (Return on Assets/Return on Equity/Return on Sales) for companies in the firm's 3-digit SIC classification over the three years prior to the proxy data.

Indicators for firm level exogenous noise

Correlation (Fisher $z$ ) be- Fisher z-scores for the correlations between accounting returns tween annual market returns (Return on Assets/Return on Equity/Return on Sales) and stock and ROA/ROE/ROS market returns over the three years prior to the proxy data.

Indicators for CEO influence

Proportion of external board Proportion of external board members, in the board of directors, members appointed after appointed by the CEO, in the year prior to the proxy data.

CEO appointment

Proportion of internal board Proportion of internal board members, in the board of directors, members appointed after appointed by the CEO, in the year prior to the proxy data.

CEO appointment

CEO shares divided by the The number of outstanding shares held by the CEO divided by the number of outstanding shares owned by external board members

CEO tenure number of outstanding shares owned by external board members.

Firm size

The manager's tenure as a CEO in years.

Natural logarithm of the firm's sales in the year prior to the proxy data. 


\section{EQUITY INCENTIVES AND PERFORMANCE MEASURES IN BONUS CONTRACTS}

\subsection{Research methodology}

Not all firms use non-accounting performance measures in CEO bonus contracts (Bushman et al. 1996; Ittner et al., 1997). As a consequence, my dependent variable, the incentive-intensity of non-accounting performance measures in the annual bonus contract, is left-censored (at zero). Therefore, I use both a Tobit model and a Heckman model to examine how the sensitivities to price and stock return volatility affect the reliance on non-price performance measures..$^{22}$ In the Tobit model I combine the decisions on the use and on the incentive-intensity of non-accounting performance measures in the CEO annual bonus contract into a single regression. The Heckman model simultaneously models these decisions (Heckman, 1979). The first stage in the Heckman procedure consists of a probit model for the decision to use non-accounting measures in the CEO's annual bonus contract. The second stage uses a linear regression model to determine the incentive-intensity of non-accounting performance measures for those firms that use non-accounting performance measures. A Tobit model can be used when the determinants and their (expected) coefficients for both stages in the Heckman model are similar. To relax these restrictions, I also include the Heckman specification.

My Tobit model for the incentive-intensity of non-accounting performance measures in the CEO's annual bonus contract is summarized as (for variable definitions see table 3.1):

$$
\begin{aligned}
& \text { PERFMEAS }=\alpha_{0}+\alpha^{S T P} \text { Sensitivity of wealth to stock price }{ }_{i}+ \\
& \alpha^{S T V} \text { Sensitivity of wealth to stock return volatility }{ }_{i}+ \\
& \alpha^{F} \text { FIRM } \\
& +\varepsilon_{i}
\end{aligned}
$$

Where:

FIRM

$=$ a vector of firm is characteristics (including industry dummy variables and year indicator variables) that are expected to affect the choice of performance measures in annual bonus contracts. All variables are defined in table 3.1.

and $\alpha^{F}$ is a vector of coefficients.

\footnotetext{
${ }^{22}$ To deal with multiple observations for a given firm, I specify my empirical tests using Rogers standard errors (Rogers, 1993; Petersen, 2005).
} 
The first equation of the Heckman model (3.2) specifies a probit regression and models the firm's choice to explicitly use any kind of non-accounting performance measures in the CEO's annual bonus contract (for variable definitions see table 3.1).

$$
\begin{aligned}
& P\left(N A M_{i}=1\right)=\alpha_{0}+\beta^{\text {STP }} \text { Sensitivity of wealth to stock } \text { price }_{i}+ \\
& \beta^{\text {STP }} \text { Sensitivity of wealth to stock return volatility }{ }_{i}+ \\
& \beta^{F} \text { FIRM }_{i}+\eta_{i}
\end{aligned}
$$

Where:

FIRM

$=$ a vector of firm is characteristics (including industry dummy variables and year indicator variables) that are expected to affect the choice of performance measures in annual bonus contracts. All variables are defined in table 3.1.

and $\beta^{F}$ is a vector of coefficients.

The second equation of the Heckman specification (3.3) models the decision for the relative weight assigned to the non-accounting measures used in the CEO's annual bonus contract conditional on the use of non-accounting performance measures. This equation includes the inverse Mills ratio $(\lambda)$ to control for possible sample selection bias (for variable definitions see table 3.1).

$($ PERFMEAS $\mid$ PERFMEAS $>0)=\gamma_{0}+\gamma^{\text {STP Sensitivity of wealth to stock price }}{ }_{i}+$

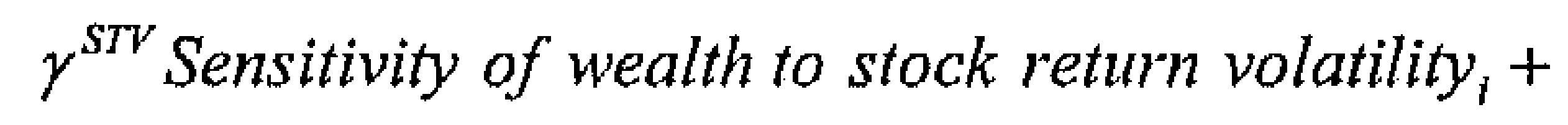

$$
\gamma^{F} F I R M_{i}+\gamma^{L} \lambda_{i}+\varphi_{i}
$$

Where:

FIRM

$=$ a vector of firm is characteristics (including industry dummy variables and year indicator variables) that are expected to affect the choice of performance measures in annual bonus contracts. All variables are defined in table 3.1 .

and $\gamma^{F}$ is a vector of coefficients. 


\section{EQUITY INCENTIVES AND PERFORMANCE MEASURES IN BONUS CONTRACTS}

\subsection{Descriptive analysis}

Panel A of table 3.2 compares the distribution (across industries) of the sample of firms that only use accounting performance measures to the sample of firms that rely on a combination of accounting and non-accounting performance measures.

Table 3.2 shows that $50 \%$ of all observations come from manufacturing firms. Approximately $19 \%$ of these firm-years use non-accounting performance measures. Consequently, manufacturing firms represent the highest proportion of my sample using a combination of accounting and non-accounting performance measures. In contrast, financial services and retail trade firms make up less than $3 \%$ of the sample of firms relying on non-accounting performance measures. Because of the large number of firm-years that report a $100 \%$ weight on accounting performance measures, panel $B$ of table 3.2 presents descriptive information for those firm-years that use non-accounting performance measures in CEO annual bonus contracts.

The mean weight placed on non-accounting performance measures for these firms ranges from a high of $44.5 \%$ in 1998 to a low of $40.3 \%$ in 2002 . This result contrasts with the belief that the use of non-accounting performance measures has increased recently (e.g., Ittner et al., 1997). However, a close look at the mean percentage of targeted cash compensation that is based on nonaccounting performance measures indicates that on average, the incentiveintensity of non-accounting performance measures has remained relatively stable for my sample firms. For non-zero observations, the mean NFCOMP varies from a high of $19.8 \%$ in 2001 to a low of $18.6 \%$ in 2002 . Panel B of table 3.2 further shows that the incentive-intensity of equity incentives for the sample of firms using non-accounting performance measures increased significantly from 1998 to $2002 .^{23}$ The median change in CEO wealth from a $1 \%$ change in stock price increased from almost $\$ 104,000$ in 1998 to over $\$ 244,000$ in 2002 . The sensitivity of CEO wealth to stock return volatility increased with a similar factor over the same period. ${ }^{24}$ The median change in value of the CEO's option portfolio holdings for a $1 \%$ change in the standard deviation of stock returns grew from approximately $\$ 34,000$ in 1998 to more than $\$ 78,000$ in 2002. These conclusions are not sensitive to a logarithmic transformation of the slope and convexity of the CEO's portfolio equity incentives.

\footnotetext{
${ }^{23}$ To mitigate the influence of outliers, each continuous explanatory variable is winsorized at the $1 \%$ level of the distribution (e.g., Core and Guay, 1999).

${ }^{24}$ Since I calculate the sensitivity of CEO wealth to stock return volatility for the CEO's option portfolio holdings, this variable takes a value of zero for those firms that do not make use of CEO stock option compensation.
} 
Table 3.2 Descriptive statistics for the reported performance measures used in CEO annual bonus contracts and hypothesized determinants

Panel A. Distribution of sample firm-years by industry over the period 1998-2002

\begin{tabular}{|c|c|c|c|c|}
\hline Industry & $\begin{array}{c}\text { Two-Digit SIC } \\
\text { Code }\end{array}$ & $\begin{array}{l}\text { Firm-years with zero } \\
\text { weights placed on non- } \\
\text { accounting perform- } \\
\text { ance measures in CEO } \\
\text { annual bonus contracts }\end{array}$ & $\begin{array}{l}\text { Firm-years with non-zero } \\
\text { weights placed on non- } \\
\text { accounting performance } \\
\text { measures in CEO annual } \\
\text { bonus contracts }\end{array}$ & Total \\
\hline Mining and Construction & $10-19$ & 49 & 9 & 58 \\
\hline Manufacturing & $20-39$ & 396 & 95 & \\
\hline $\begin{array}{l}\text { Manufacturing (non- } \\
\text { durables) }\end{array}$ & $20-29$ & 165 & 71 & 236 \\
\hline $\begin{array}{l}\text { Manufacturing } \\
\text { (durables) }\end{array}$ & 30.39 & 231 & 24 & 255 \\
\hline $\begin{array}{l}\text { Transportation and } \\
\text { Utilities }\end{array}$ & $40-49$ & 96 & 43 & 139 \\
\hline Wholesalers Trade & $50-51$ & 42 & 14 & 56 \\
\hline Retail Trade & $52-59$ & 134 & 2 & 136 \\
\hline Financial Services & $60-69$ & 21 & 3 & 24 \\
\hline $\begin{array}{l}\text { Consumer and } \\
\text { Business Services }\end{array}$ & $70-89$ & 75 & 18 & 93 \\
\hline
\end{tabular}

\begin{tabular}{llll}
\hline Total & 813 & 184 & 997 \\
\hline
\end{tabular}

Panel B. Trends in the relative importance of non-accounting performance measures in CEO annual bonus contracts and CEO portfolio equity incentives (sensitivity of CEO wealth to stock price and sensitivity of CEO wealth to stock return volatility) over the period 1998-2002

\begin{tabular}{|c|c|c|c|c|c|}
\hline Variable & 1998 & 1999 & 2000 & 2001 & 2002 \\
\hline Total number of firms & 162 & 181 & 199 & 229 & 226 \\
\hline \multicolumn{6}{|c|}{ Use of non-accounting performance measures in CEO annual bonus contracts: } \\
\hline $\begin{array}{l}\text { Percentage of firms with } \\
\text { non-zero weights placed } \\
\text { on non-accounting } \\
\text { performance measures }\end{array}$ & $22.22 \%$ & $19.89 \%$ & $17.59 \%$ & $15.72 \%$ & $18.14 \%$ \\
\hline $\begin{array}{l}\text { Reiative weights placed on } \\
\text { non-accounting perform } \\
\text { ance measures }\end{array}$ & $\begin{array}{c}0.445 \\
(0.333)\end{array}$ & $\begin{array}{c}0.435 \\
(0.337)\end{array}$ & $\begin{array}{c}0.437 \\
(0.333)\end{array}$ & $\begin{array}{c}0.422 \\
(0.300)\end{array}$ & $\begin{array}{c}0.403 \\
(0.340)\end{array}$ \\
\hline $\begin{array}{l}\text { Percentage of short-term } \\
\text { compensation based on } \\
\text { non-accounting perform } \\
\text { ance measures }\end{array}$ & $\begin{array}{c}0.191 \\
(0.138)\end{array}$ & $\begin{array}{c}0.194 \\
(0.153)\end{array}$ & $\begin{array}{c}0.193 \\
(0.130)\end{array}$ & $\begin{array}{c}0.198 \\
(0.141)\end{array}$ & $\begin{array}{c}0.186 \\
(0.163)\end{array}$ \\
\hline \multicolumn{6}{|c|}{ Sensitivity of CEO wealth to stock price: } \\
\hline $\begin{array}{l}\text { Percentage of firms with a } \\
\text { non-zero sensitivity to } \\
\text { price }\end{array}$ & $100.00 \%$ & $100.00 \%$ & $100.00 \%$ & $100,00 \%$ & $100.00 \%$ \\
\hline Sensitivity to price ${ }^{1}$ & $\begin{array}{c}470,681 \\
(103,910)\end{array}$ & $\begin{array}{c}623,806 \\
(139,804)\end{array}$ & $\begin{array}{c}578,124 \\
(118,520)\end{array}$ & $\begin{array}{c}929,688 \\
(188,203)\end{array}$ & $\begin{array}{l}1208,680 \\
(244,432)\end{array}$ \\
\hline $\log \left(\right.$ Sensitivity to price) ${ }^{1}$ & $\begin{array}{c}4.775 \\
(4.652)\end{array}$ & $\begin{array}{c}5.169 \\
(4.947)\end{array}$ & $\begin{array}{c}5.102 \\
(4.783)\end{array}$ & $\begin{array}{c}5.453 \\
(5.240)\end{array}$ & $\begin{array}{c}5.650 \\
(5.503)\end{array}$ \\
\hline \multicolumn{6}{|c|}{ Sensitivity of CEO wealth to stock return volatility: } \\
\hline $\begin{array}{l}\text { Percentage of firms with a } \\
\text { non-zero sensitivity to volatility }\end{array}$ & $91.98 \%$ & $93.92 \%$ & $93.97 \%$ & $95.20 \%$ & $95.58 \%$ \\
\hline Sensitivity to volatility ${ }^{1}$ & $\begin{array}{c}63,114 \\
(33,936)\end{array}$ & $\begin{array}{c}90,605 \\
(53,733)\end{array}$ & $\begin{array}{l}110,476 \\
(51,259)\end{array}$ & $\begin{array}{l}132,577 \\
(69,286)\end{array}$ & $\begin{array}{l}165,239 \\
(78,594)\end{array}$ \\
\hline $\begin{array}{l}\log (\text { Sensitivity to } \\
\text { volatility) }\end{array}$ & $\begin{array}{c}3.412 \\
(3.554)\end{array}$ & $\begin{array}{c}3.882 \\
(3.998)\end{array}$ & $\begin{array}{c}3.917 \\
(3.956)\end{array}$ & $\begin{array}{c}4.239 \\
(4.250)\end{array}$ & $\begin{array}{l}4.416 \\
(4.377)\end{array}$ \\
\hline
\end{tabular}


EQUITY INCENTIVES AND PERFORMANCE MEASURES IN BONUS CONTRACTS

Table 3.2 (Continued)

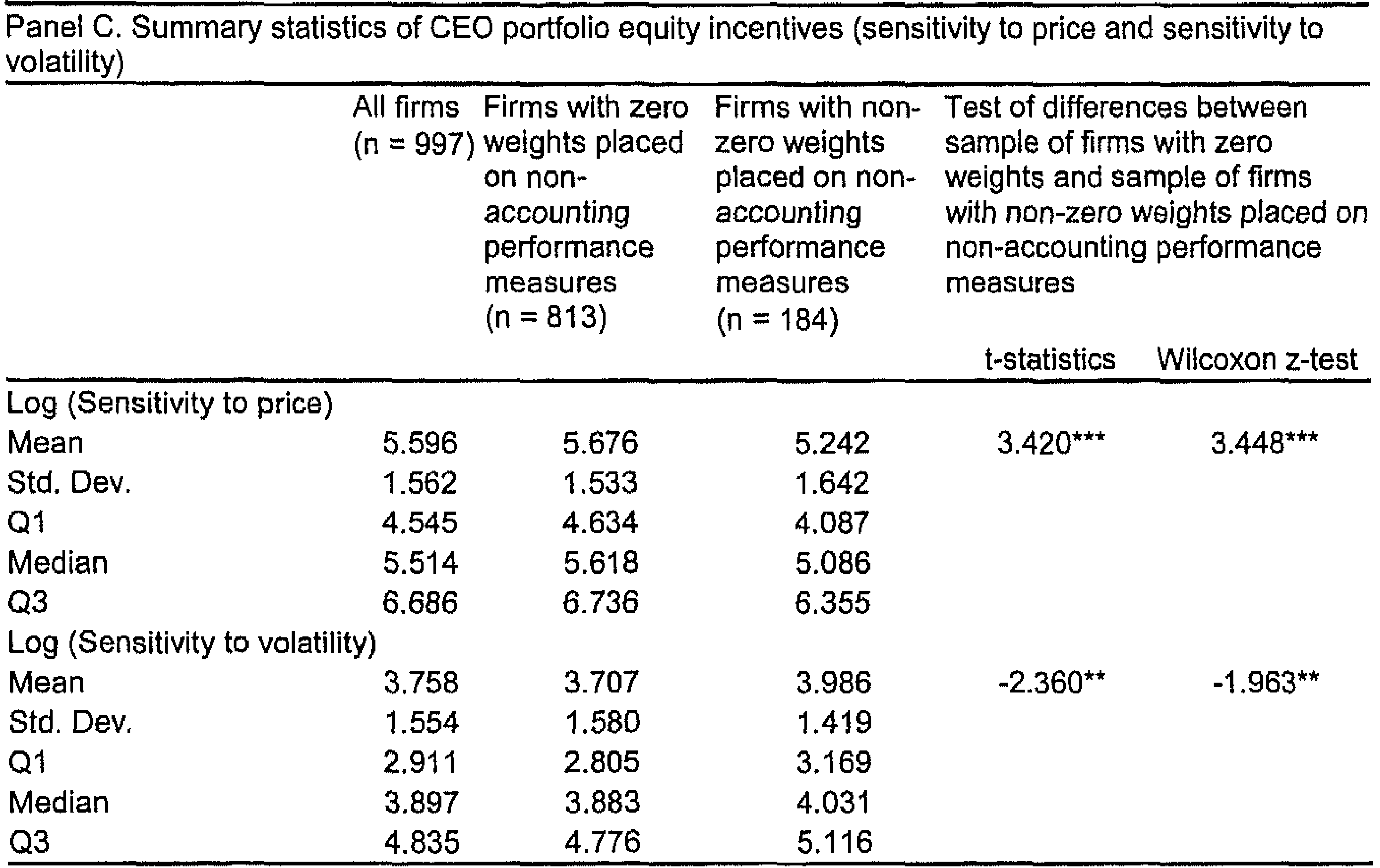

Notes:

Panel B reports mean values (median values are reported in parentheses) except for percentages.

1 Statistics are caiculated on the subsample of firms with non-zero weights placed on non-accounting performance measures.

Variables are defined in table 3.1.

${ }_{* \star *}^{* * *},{ }^{*}{ }^{\dagger}$ denotes statistical significance at the $0.01,0.05,0.10$ and 0.15 level (two-tailed).

The mean of the $\log$ (Sensitivity to price) increased from 4.78 in 1998 to 5.65 in 2002. The mean of the $\log$ (Sensitivity to volatility) increased from 3.41 to 4.42 during the sample period. Since the logarithmic functional forms are much less skewed, these are used as measures in my tests (e.g., Core and Guay, 1999; Guay, 1999).

In panel $\mathrm{C}$ of table 3.2 I compare the slope and convexity of the wealthperformance relation for firms using both accounting and non-accounting measures against firms using only accounting performance measures. For the sensitivity of the CEO's holdings of stock and options to stock price, mean $\log$ (Sensitivity to price) is significantly lower in firms using non-accounting performance measures (5.68 versus 5.24 ). In contrast, mean sensitivity of the CEO's options to the volatility of firm value ( $\log ($ Sensitivity to volatility)) is significantly higher for firms using non-accounting measures (3.71 versus 3.99). Nonparametric tests provide similar results. These tests provide initial support for my hypotheses. 
Table 3.3 Summary statistics of the economic factors that determine the use of non-accounting performance measures in CEO annual bonus contracts $(n=997)$

\begin{tabular}{|c|c|c|c|c|c|}
\hline Variable & Mean & Std. Dev. & Q1 & Median & Q3 \\
\hline $\begin{array}{l}\text { Financial health } \\
\text { Indicators for Strategy }\end{array}$ & 4.887 & 4.246 & 2.258 & 3.750 & 5.780 \\
\hline Research \& development to sales & 0.041 & 0.138 & 0.000 & 0.000 & 0.021 \\
\hline Market-to-book & 3.215 & 2.643 & 1.652 & 2.452 & 3.900 \\
\hline Sales growth & 0.159 & 0.186 & 0.042 & 0.114 & 0.222 \\
\hline Product life cycle & 0.617 & 0.486 & 0.000 & 1.000 & 1.000 \\
\hline Product development cycle & 0.375 & 0.484 & 0.000 & 0.000 & 1.000 \\
\hline Standard deviation of stock returns & 0.114 & 0.046 & 0.080 & 0.105 & 0.139 \\
\hline $\begin{array}{l}\text { Log(Standard deviation of stock returns) } \\
\text { Indicators for Industry level exogenous noise }\end{array}$ & -2.250 & 0.397 & -2.522 & -2.257 & -1.971 \\
\hline Standard deviation of median ROA & 0.019 & 0.021 & 0.006 & 0.012 & 0.025 \\
\hline Standard deviation of median ROE & 0.048 & 0.045 & 0.026 & 0.038 & 0.056 \\
\hline $\begin{array}{l}\text { Standard deviation of median ROS } \\
\text { Indicators for Firm level exogenous noise }\end{array}$ & 0.022 & 0.031 & 0.006 & 0.011 & 0.020 \\
\hline $\begin{array}{l}\text { Correlation (Fisher z) between annual market } \\
\text { retums and ROA }\end{array}$ & 0.178 & 1.476 & -0.747 & 0.126 & 1.040 \\
\hline $\begin{array}{l}\text { Correlation (Fisher } z \text { ) between annual market } \\
\text { returns and ROE }\end{array}$ & 0.223 & 1.483 & -0.676 & 0.200 & 1.131 \\
\hline $\begin{array}{l}\text { Correlation (Fisher } \mathrm{z} \text { ) between annual market } \\
\text { returns and ROS }\end{array}$ & 0.145 & 1.391 & -0.725 & 0.121 & 0.979 \\
\hline Indicators for CEO influence & & & & & \\
\hline $\begin{array}{l}\text { Proportion of external board members appointed } \\
\text { after CEO appointment }\end{array}$ & 0.593 & 0.317 & 0.364 & 0.600 & 0.857 \\
\hline $\begin{array}{l}\text { Proportion of internal board members appointed } \\
\text { after CEO appointment }\end{array}$ & 0.349 & 0.435 & 0.000 & 0.000 & 1.000 \\
\hline $\begin{array}{l}\text { CEO shares divided by the number of outstanding } \\
\text { shares owned by external board members }\end{array}$ & 11.868 & 18.572 & 1.264 & 4.002 & 11.807 \\
\hline CEO tenure & 10.945 & 8.280 & 5.417 & 8.583 & 13.917 \\
\hline $\log ($ CEO tenure) & 2.286 & 0.609 & 1.859 & 2.260 & 2.702 \\
\hline Firm size (in million \$) & 3,386 & 6,501 & 557.5 & 1,333 & 2,821 \\
\hline
\end{tabular}

Notes:

Variables are defined in Table 3.1.

Table 3.3 provides descriptive statistics for the firm characteristics that may affect the choice of performance measures. The sample firms are relatively large, having median sales of over $\$ 1$ billion. The mean and median values of Financial health, both being above 3 , indicate that, on average sample firmyears have little chance of bankruptcy. Only a minority of firm-years reports Altman Z-scores below 1.8, having a large chance of bankruptcy. The firm-years in my sample show substantial variation in strategic focus. The mean (median) market-to-book ratio is 3.215 (2.452) and mean (median) sales growth is $15.9 \%$ $(11.4 \%)$. Following the classification scheme from the National Academy of Engineering (1992), I classify 382 firm-years as having short and 615 firm-years as having long product life cycles. Using product development cycles, I categorize 623 firm-years as having short and 374 firm-years as having long product development cycles. The results of this classification are similar to Said et al. (2003). In line with Ittner et al. (2003), mean (median) values for stock price volatility are $0.114(0.105)$. Distributions for the industry level noise are compa- 
rable to Ittner et al., 1997. Firm level correlations between accounting and stock market returns are lower than the values reported by Ittner et al. (1997). Likewise, some of my indicators for CEO influence also differ from Ittner et al. $(1997) \cdot{ }^{25}$

Table 3.4 Correlation coefficients between the independent variables $(n=997)$

\begin{tabular}{|c|c|c|c|c|c|c|c|c|c|c|c|}
\hline Variable & 1 & 2 & 3 & 4 & 5 & 6 & 7 & 8 & 9 & 10 & 11 \\
\hline 1. Log (Sensitivity to price) & 1.00 & 0.52 & 0.30 & 0.42 & -0.11 & -0.17 & 0.14 & 0.14 & -0.06 & 0.41 & 0.32 \\
\hline $\begin{array}{l}\text { 2. Log (Sensitivity to } \\
\text { volatility) }\end{array}$ & 0.44 & 1.00 & -0.03 & 0.23 & -0.06 & 0.00 & 0.09 & 0.13 & -0.03 & 0.08 & 0.49 \\
\hline 3. Financial health & 0.24 & -0.08 & 1.00 & 0.42 & -0.15 & -0.34 & 0.29 & 0.23 & -0.09 & 0.13 & -0.22 \\
\hline 4. Strategy & 0.30 & 0.19 & 0.51 & 1.00 & -0.09 & -0.08 & 0.31 & 0.19 & -0.04 & 0.11 & -0.01 \\
\hline 5. Product life cycle & -0.11 & -0.06 & -0.08 & -0.07 & 1.00 & 0.56 & -0.28 & -0.19 & -0.06 & -0.03 & 0.07 \\
\hline $\begin{array}{l}\text { 6. Product development } \\
\text { cycle }\end{array}$ & -0.18 & 0.01 & -0.20 & 0.01 & 0.56 & 1.00 & -0.27 & -0.06 & 0.00 & -0.11 & 0.08 \\
\hline $\begin{array}{l}\text { 7. Log (Standard deviation } \\
\text { of stock returns) }\end{array}$ & 0.14 & 0.12 & 0.30 & 0.35 & -0.28 & -0.28 & 1.00 & 0.43 & 0.03 & 0.18 & -0.34 \\
\hline $\begin{array}{l}\text { 8. Industry level exoge } \\
\text { nous noise }\end{array}$ & 0.11 & 0.13 & 0.26 & 0.37 & -0.15 & 0.03 & 0.40 & 1.00 & 0.08 & 0.06 & -0.25 \\
\hline $\begin{array}{l}\text { 9. Firm level exogenous } \\
\text { noise (inverse measure) }\end{array}$ & -0.05 & -0.03 & -0.07 & -0.03 & -0.05 & 0.00 & 0.03 & 0.07 & 1.00 & -0.04 & -0.04 \\
\hline 10. CEO influence & 0.43 & 0.04 & 0.11 & 0.05 & -0.03 & -0.12 & 0.18 & 0.08 & -0.03 & 1.00 & -0.01 \\
\hline 11. Firm size & 0.35 & 0.43 & -0.27 & -0.16 & 0.03 & 0.03 & -0.38 & -0.30 & -0.02 & 0.00 & 1.00 \\
\hline
\end{tabular}

Table 3.4 presents the Pearson and Spearman correlations between the independent variables, none of which cause multicollinearity concerns. Table 3.4 shows that volatility and price sensitivities of managerial equity portfolios are positively correlated. This result follows from the fact that the same equity holdings drive both sensitivities. Additionally, CEOs in larger firms have more wealth tied to the firm's equity than CEOs in smaller firms. Similarly, CEOs in innovative firms (i.e. firms with higher scores for the Strategy measure) have more wealth tied to the firm's equity than CEOs in firms that follow a cost leader strategy (i.e. firms with lower scores for the Strategy measure). Innovative firms also exhibit higher degrees of environmental uncertainty (Log(Standard deviation of stock returns)) and a higher variance in industry financial accounting measures (Industry level exogenous noise). The results in table 3.4 further show that CEO influence is positively correlated with the sensitivity to stock price. Additionally, there

\footnotetext{
${ }^{25}$ Principal component analysis reveals that each of the indicators used to measure the underlying constructs for Strategy, Industry level exogenous noise, Firm level exogenous noise and CEO influence, have factor loadings above 0.65 .
} 
is also a significant positive correlation between product development cycle and product life cycle which follows earlier results by Bushman et al. (1996).

\subsection{Results}

Table 3.5 reports the results of the Tobit analysis of the relation between the reliance on non-accounting performance measures in the CEO's annual bonus contract and the expected determinants. The results provide support for the view that performance measures in CEO compensation contracts are interrelated. More specifically, I find that the relative weight assigned to non-accounting performance measures in the CEO's annual bonus contract is negatively associated with the sensitivity of the CEO's wealth to stock price. Since my dependent variable is an inverse measure of the reliance on accounting measures in CEO annual bonus contracts, this means that the sensitivity of the CEO's wealth to stock price is positively related to the weight assigned to accounting performance measures in CEO annual bonus contracts $(p<0.01)$. This finding confirms hypothesis 1 and indicates that accounting measures complement the incentives provided by the sensitivity of the CEO's wealth to stock price. The reason for this is that accounting information is already available for other purposes. In addition, accounting performance measures are understandable, conservative, quantitative and verifiable by third parties. Accounting measures are also highly aggregated, which ensures that they capture the effect of all managerial actions. Furthermore, while stock prices are forward-looking and align the long-run objectives of shareholders and managers, accounting measures ensure shortterm operational performance. Finally, accounting performance measures, such as earnings, help shield executives from market-wide risks in equity values. Thus, while the slope of the wealth performance relation induces long-run value creation, accounting performance measures, which are understandable, conservative, quantitative and verifiable by third parties, ensure short-term operational performance and shield CEOs from macroeconomic risk. This explains why the sensitivity of the CEO's wealth to stock price is positively related to the weight assigned to accounting performance measures in CEO annual bonus contracts and confirms hypothesis 1 .

Table 3.5 also provides evidence consistent with hypothesis 2 , that the sensitivity of CEO stock option portfolio holdings to stock return volatility is positively associated with the reliance on non-accounting performance measures in CEO annual bonus contracts $(p<0.01)$. This result reflects that firms use nonaccounting performance measures to encourage managerial actions along those risk dimensions that shareholders prefer. The remaining explanatory variables provide results consistent with prior research. Firms following an innovative strategy (i.e., firms with higher scores for the Strategy measure) rely more on 


\section{EQUITY INCENTIVES AND PERFORMANCE MEASURES IN BONUS CONTRACTS}

non-accounting performance measures in the annual bonus contract (Ittner et al., 1997; Said et al., 2003). Likewise, firms with longer product development cycles place relatively more weight on non-accounting metrics (Bushman et al., 1996).

Table 3.5 Tobit regression results for the relative weights placed on non-accounting performance measures in CEO annual bonus contracts (PERFMEAS) and the percentage of short-term compensation based on non-accounting performance measures in CEO annual bonus contracts (NFCOMP) over the period $1998-2002(n=997)$

\begin{tabular}{|c|c|c|c|}
\hline \multirow[b]{2}{*}{ Independent Variable } & \multirow[b]{2}{*}{ Expected sign } & \multicolumn{2}{|c|}{ Coefficient Estimate } \\
\hline & & PERFMEAS & NFCOMI \\
\hline Log (Sensitivity to price) & - & $\begin{array}{l}-0.13^{\star \star \star} \\
(-3.07)\end{array}$ & $\begin{array}{l}-0.06^{\star \star *} \\
(-3.06)\end{array}$ \\
\hline Log (Sensitivity to volatility) & + & $\begin{array}{l}0.10^{\star \star *} \\
(2.74)\end{array}$ & $\begin{array}{l}0.05^{\star \star \star \hbar} \\
(2.81)\end{array}$ \\
\hline Financial health & + & $\begin{array}{c}0.01 \\
(0.72)\end{array}$ & $\begin{array}{c}0.00 \\
(0.67)\end{array}$ \\
\hline Strategy & + & $\begin{array}{c}0.12^{\star \star} \\
(2.39)\end{array}$ & $\begin{array}{l}0.06^{\star \star \star} \\
(2.64)\end{array}$ \\
\hline Product life cycle & + & $\begin{array}{c}0.20 \\
(1.29)\end{array}$ & $\begin{array}{c}0.09 \\
(1.24)\end{array}$ \\
\hline Product development cycle & + & $\begin{array}{l}0.34^{* * *} \\
(2.48)\end{array}$ & $\begin{array}{c}0.16^{\star \star \star} \\
(2.53)\end{array}$ \\
\hline Log (Standard deviation of stock returns) & + & $\begin{array}{l}-0.08 \\
(-0.45)\end{array}$ & $\begin{array}{l}-0.04 \\
(-0.44)\end{array}$ \\
\hline Industry level exogenous noise & + & $\begin{array}{r}0.09^{\dagger} \\
(1.61)\end{array}$ & $\begin{array}{c}0.04^{t} \\
(1.60)\end{array}$ \\
\hline Firm level exogenous noise (inverse measure) & - & $\begin{array}{c}0.01 \\
(0.31)\end{array}$ & $\begin{array}{c}0.00 \\
(0.21)\end{array}$ \\
\hline CEO influence & $?$ & $\begin{array}{l}-0.05 \\
(-0.79)\end{array}$ & $\begin{array}{l}-0.02 \\
(-0.78)\end{array}$ \\
\hline Firm size & $?$ & $\begin{array}{c}0.04 \\
(0.62)\end{array}$ & $\begin{array}{c}0.01 \\
(0.48)\end{array}$ \\
\hline
\end{tabular}

Number of non-censored observations

Number of censored observations

Percentage

$184 \quad 184$

$81.54 \% \quad 81.54 \%$

\begin{tabular}{lll}
\hline Adjusted $\mathrm{R}^{2}$ & $13.70 \%$ & $19.80 \%$ \\
\hline
\end{tabular}

Notes:

The sample consists of 997 firm-year observations (269 firms) over the period 1998-2002. T-statistics (in parentheses) are based on Rogers standard errors. Coefficients on an intercept, 6 industry indicator variables and 4-year indicator variables are not reported. Variables are defined in table 3.1. $\star \star \star * *{ }^{*},{ }^{\dagger}$ denotes statistical significance at the $0.01,0.05,0.10$ and 0.15 level (two-tailed). 
Finally, the positive coefficient of Industry level exogenous noise supports the claim that exogenous noise in accounting measures results in more emphasis on non-accounting performance measures in CEO annual bonus contracts (Ittner et al., 1997). ${ }^{26}$ The results for the NFCOMP measure, which takes into account the amount of targeted cash compensation that is at risk based on nonaccounting performance measures lead to similar inferences, supporting both hypotheses.

As indicated, the Tobit model restricts the coefficients on the explanatory variables to be the same in both the decision to use non-accounting performance measures in the CEO's annual bonus contract and the decision on the incentive-intensity assigned to these non-accounting performance measures in the CEO's annual bonus contract. Table 3.6 presents the Heckman specification that examines these choices separately.

For the probit model, I find that there is a negative relationship between the price sensitivity of the CEO's stock and stock option portfolio and the use of nonaccounting performance measures in CEO annual bonus contracts. Conversely, the use of non-accounting measures is greater as the sensitivity of the CEOs option portfolio to stock return volatility increases. The OLS results provide no support for a relation between the slope and the convexity of the wealthperformance relation and the incentive-intensity placed on non-accounting performance measures for firms that use non-accounting measures.

The results from the Heckman specification could be seen as evidence that the CEO's portfolio equity incentives are associated with the reliance on nonaccounting measures through the probability to make use of non-accounting measures, but not through a relation with the relative weight assigned to these non-accounting performance measures. However, caution is required, because the result in the OLS second stage of the Heckman specification can be driven by a lack of variance in the dependent variable. The weight on non-accounting measures for firms using non-accounting measures fluctuates around $35 \%$, consequently there might simply not be enough variance to detect a significant relation between the CEOs portfolio equity incentives and the positive weight assigned to non-accounting measures in the CEOs annual bonus contract.

With respect to my control variables, I find that longer time horizons for product development cycles and the exogenous noise in a firm's accounting performance measures are positively associated with the use of non-accounting performance measures. Once non-accounting measures are incorporated in the CEO's annual bonus contract, their incentive-intensity remains to be positively

\footnotetext{
${ }^{26}$ Results for both the Tobit model and the Heckman specification are unaffected (not tabulated) if I control for firm performance by including current year and prior year stock returns (e.g., Core and Guay, 1999).
} 


\section{EQUITY INCENTIVES AND PERFORMANCE MEASURES IN BONUS CONTRACTS}

affected by length of the product development cycle. The second stage OLS regression further shows that firms operating in less predictable, or noisier environments rely more heavily on non-accounting measures in the CEO's annual bonus contract. The results for non-zero NFCOMP observations in the second stage OLS regression are similar to those having non-zero PERFMEAS values.

Table 3.6 Heckman two-stage estimation of the determinants of the reliance on non-accounting performance measures in CEO annual bonus contracts over the period 1998-2002

\begin{tabular}{|c|c|c|c|c|}
\hline \multirow[b]{2}{*}{ Independent Variable } & \multirow[b]{2}{*}{$\begin{array}{l}\text { Expected } \\
\text { sign }\end{array}$} & \multicolumn{3}{|c|}{ Coefficient Estimate } \\
\hline & & $\begin{array}{l}\text { Probit } \\
\text { NAM }\end{array}$ & $\begin{array}{c}\text { OLS } \\
\text { PERFMEAS } \\
>0\end{array}$ & $\begin{array}{c}\text { OLS } \\
\text { NFCOMP } \\
>0\end{array}$ \\
\hline Log (Sensitivity to price) & - & $\begin{array}{l}-0.22^{\star \star \star} \\
(-2.93)\end{array}$ & $\begin{array}{c}0.02 \\
(0.42)\end{array}$ & $\begin{array}{c}0.02 \\
(1.26)\end{array}$ \\
\hline Log (Sensitivity to volatility) & + & $\begin{array}{l}0.16^{\star \star *} \\
(2.47)\end{array}$ & $\begin{array}{c}0.04 \\
(1.35)\end{array}$ & $\begin{array}{c}0.01 \\
(1.12)\end{array}$ \\
\hline Financial health & + & $\begin{array}{c}0.02 \\
(0.72)\end{array}$ & $\begin{array}{c}0.00 \\
(-0.81)\end{array}$ & $\begin{array}{c}0.00 \\
(-1.06)\end{array}$ \\
\hline Strategy & + & $\begin{array}{c}0.13 \\
(1.28)\end{array}$ & $\begin{array}{l}0.05^{\star \star} \\
(2.26)\end{array}$ & $\begin{array}{l}0.03^{\star \star \star} \\
(3.04)\end{array}$ \\
\hline Product life cycle & + & $\begin{array}{l}0.38 \\
(1.34)\end{array}$ & $\begin{array}{l}-0.06 \\
(-0.78)\end{array}$ & $\begin{array}{c}-0.05 \\
(-1.23)\end{array}$ \\
\hline Product development cycle & + & $\begin{array}{c}0.57^{* *} \\
(2.12)\end{array}$ & $\begin{array}{c}0.18^{\star \star} \\
(2.33)\end{array}$ & $\begin{array}{c}0.08^{* *} \\
(2.23)\end{array}$ \\
\hline Log (Standard deviation of stock returns) & + & $\begin{array}{l}-0.35 \\
(-1.09)\end{array}$ & $\begin{array}{l}0.39^{\star \star \star} \\
(4.06)\end{array}$ & $\begin{array}{l}0.18^{\star \star \star} \\
(3.55)\end{array}$ \\
\hline Industry level exogenous noise & + & $\begin{array}{r}0.15^{\dagger} \\
(1.47)\end{array}$ & $\begin{array}{c}0.00 \\
(0.17)\end{array}$ & $\begin{array}{c}0.00 \\
(0.00)\end{array}$ \\
\hline $\begin{array}{l}\text { Firm level exogenous noise (inverse } \\
\text { measure) }\end{array}$ & - & $\begin{array}{c}0.01 \\
(0.17)\end{array}$ & $\begin{array}{c}0.01 \\
(0.91)\end{array}$ & $\begin{array}{c}0.00 \\
(-0.01)\end{array}$ \\
\hline CEO influence & $?$ & $\begin{array}{l}-0.10 \\
(-0.87)\end{array}$ & $\begin{array}{l}-0.02 \\
(-1.16)\end{array}$ & $\begin{array}{c}-0.01 \\
(-1.09)\end{array}$ \\
\hline Firm size & $?$ & $\begin{array}{c}0.06 \\
(0.62)\end{array}$ & $\begin{array}{l}-0.01 \\
(-0.37)\end{array}$ & $\begin{array}{l}-0.01 \\
(-0.97)\end{array}$ \\
\hline Lambda & $?$ & & $\begin{array}{c}0.00 \\
(-0.03)\end{array}$ & $\begin{array}{c}-0.02 \\
(-0.52)\end{array}$ \\
\hline
\end{tabular}

Notes:

The Heckman procedure consists of a first stage probit estimation for the decision to use nonaccounting measures ( $n=997 ; 269$ firms), and a second stage OLS estimation of the relative importance of non-accounting performance measures in CEO annual bonus contracts ( $n=184 ; 56$ firms). The second stage is estimated separately for the relative weights placed on non-accounting performance measures in CEO annual bonus contracts (PERFMEAS) and the percentage of short-term compensation based on non-accounting performance measures in $C E O$ annual bonus contracts (NFCOMP). The first stage results reported here are based on the Heckman procedure for the relative weights placed on non-accounting performance measures in CEO annual bonus contracts (PERFMEAS). These reported results are both qualitatively and quantitatively similar to the first stage results based on the Heckman procedure for the percentage of short-term compensation based on nonaccounting performance measures in CEO annual bonus contracts (NFCOMP).

T-statistics (in parentheses) are based on Rogers standard errors. Coefficients on an intercept, 6 industry indicator variables and 4-year indicator variables are not reported. Variables are defined in table 3.1.

$\star \star \star * * *,{ }^{\dagger}$ denotes statistical significance at the $0.01,0.05,0.10$ and 0.15 level (two-tailed). 


\section{CHAPTER 3}

\subsection{Summary and conclusion}

In this study, I examine the interrelation between price and non-price-based performance measures in CEO compensation contracts. I find that the CEO's equity portfolio holdings affect performance measurement choices in CEO annual bonus contracts. To capture CEOs' price-based incentives, I separately estimate the sensitivity of their stock and option portfolios to price and the sensitivity of their option portfolios to return volatility. The results show that as the sensitivity of the total portfolio to price increases, the role of accounting performance measures in CEO annual bonus contracts increases. Furthermore, as the sensitivity of the option portfolio to return volatility increases, the role of nonaccounting performance measures in CEO annual bonus contracts increases. Both results yield support for my hypotheses that performance measures in CEO annual bonus contracts are used to overcome deficiencies in price-based performance measures. Accounting performance measures play a risk shielding role, i.e., protect executive compensation from market-wide fluctuations in equity values. Non-accounting performance measures play a risk steering role, i.e., induce CEOs to take those firm-specific risks that shareholders want to be taken.

As with any empirical study, my study has its limitations. First, I cannot explicitly rule out the possibility that the sensitivities of CEOs' stock and option portfolios to price and CEOS' option portfolios to return volatility are endogenous in my empirical model. However, based on previous literature, I control for various firm characteristics, and I am not aware of any variable that affects the independent variables and also determines the dependent variable in addition to these control variables.

A second limitation of my study is that I only consider accounting and nonaccounting performance measures in aggregate terms. It may be the case that specific accounting-based performance measures (e.g., earnings, revenue, return on sales, etc.) are more effective in shielding CEO compensation from market-wide fluctuations in equity values than others. Similarly, the risk steering effectiveness of some non-accounting performance measures (e.g., new product development) may differ from alternate non-accounting measures (e.g., customer satisfaction). Future research can examine to what extent more specific accounting and non-accounting performance measures in CEO annual bonus contracts differ in their role as risk management devices. 


\section{Chapter 4}

\section{Option-based equity incentives and earnings management: the role of performance measures in annual bonus contracts}

\subsection{Introduction}

In this chapter I examine to what extent the relation between CEO stock option compensation and earnings management is affected by the use of nonaccounting performance measures in CEO annual bonus contracts. While stock options are commonly used in executive compensation contracts to align the interests of executives with those of shareholders, stock option compensation also creates opportunistic incentives for managers. Recent empirical research shows that stock option compensation induces managers to use their accounting discretion to manage earnings to influence the stock price of the firm (e.g., Cheng and Warfield, 2005). This study contributes to the literature by showing that the use of non-accounting performance measures in CEO annual bonus contracts mitigates option compensation-induced earnings management.

I argue that market participants condition their beliefs about firm value on accounting and non-accounting performance. The variation of bonus payments to the CEO that is unexplained by observable accounting performance allows market participants to infer non-accounting performance for those firms using non-accounting performance measures in their CEO bonus contract. In these firms, bonus contracts act as a disciplining mechanism and managers have lower incentives to manage reported earnings, since earnings management is less likely to influence these firms' stock price.

The use of stock options to pay executives has increased significantly in the U.S. during the last two decades. Since stock options become more valuable with higher share prices, they encourage management to focus on stock prices. This creates divergent incentives. Stock options can induce managers to take actions that maximize shareholder wealth, but can also lead to earnings management to influence stock price around option grant periods or around the time 
period in which the options are exercised. In this chapter, I focus on the link from stock option compensation to earnings management.

The incentives for earnings management arise from market participants who use earnings to forecast firm value. In an effort to affect market assessments of the firm's prospects, management is expected to manipulate earnings. I argue that market participants incorporate all relevant publicly available information on current managerial action to make a rational forecast of firm value. This means that market participants will also rely on non-accounting performance in their effort to value the firm, because these measures are expected to be leading indicators of future financial performance.

Market participants can use the variation in current compensation that is not explained by variation in current observable accounting performance to infer performance on non-accounting performance measures for firms using these measures in their CEO annual bonus contract. This relation is expected to be stronger in firms that place a higher weight on non-accounting performance measures in the annual bonus contract, because these firms' bonus payments contain more information about future performance. Since earnings management is less likely to influence these firms' stock prices, I predict that managers in these firms manage earnings less. Thus, I examine whether greater reliance on non-accounting performance measures in CEO annual bonus contracts decreases option-driven earnings management.

In my analyses, 1 distinguish three option categories. Since 1 argue that managers will try to maximize stock price around exercise periods, I first distinguish exercisable and unexercisable option holdings. With respect to exercisable option holdings, I expect earnings management intensity to be positively associated with the sensitivity of the CEO's exercisable option holdings to the price of the underlying stock. I have no prediction for the relation between earnings management intensity and the sensitivity of the CEO's unexercisable option holdings to stock price. As a third category, 1 include the sensitivity of the CEO's newly granted options to stock price. Managers are predicted to manage earnings to minimize stock price around grant periods in order to reduce the option grant's exercise price, which equals grant date stock price for the majority of all option grants. In terms of my hypothesis, this means that greater reliance on non-accounting performance measures in CEO annual bonus contracts is specifically expected to decrease earnings management related to the incentiveintensity of the CEO's exercisable option holdings and the magnitude of the CEO's newly granted stock options.

To conduct my study, I employ an extensive dataset of firms that provide detailed information in their proxy statements on the performance measures used in their annual bonus contracts over the period 1998-2002. Following prior research (e.g., Ittner et al., 1997), I focus my analyses on formal compensation 
contracts where the relative weights placed on accounting and non-accounting performance measures are known to the CEO and disclosed in the proxy statement on an ex ante basis. Consistent with my hypothesis, I find that the reliance on non-accounting performance measures in CEO annual bonus contracts curtails option-driven earnings management. In particular, I show a negative impact of the use of non-accounting performance measures on the relation between earnings management and the sensitivity to price of the CEO's newly granted options. I find no clear effect for the association between earnings management and the incentive-intensity of the CEO's exercisable and unexercisable option holdings. This can be explained by the idea that the exercise price of option grants is determined at the grant date, at which the stock price is supposed to have the level desired by the CEO, which is most likely accomplished via earnings management. In contrast, since the exercise period of exercisable options covers a longer time span at which the stock price might be high already, earnings management is not always necessary. These results show that observed compensation contracts and bonus payments affect outsiders' perceptions of the value of the firm. Consequently, managers will not find it worthwhile to manage earnings to influence market participants once the market observes non-accounting performance that is used to reward the performance of top managers.

In my analyses, I control for several factors that have been shown to influence reported earnings. Consistent with prior research, I find that the magnitude of reported earnings varies with the CEO's stockholdings and the level of the firm's net operating assets, implicit claims and leverage. Robustness checks, in which I control for the informativeness of accounting earnings corroborate my main findings.

I contribute to the literature in the following ways. First, I extend research on compensation related earnings management. While previous studies that analyze the relation between compensation contracts and earnings management focus on one component in the contracting structure, I employ a more comprehensive view by considering the interplay between compensation contract components. I demonstrate that the use of non-accounting performance measures in CEO annual bonus contracts successfully offsets opportunistic earnings management incentives provided by option compensation. This finding is of interest to compensation committees that evaluate compensation contracts for managers. Additionally, this result addresses concerns from investors and policy makers that certain compensation practices affect resource allocation decisions.

This study also contributes to the compensation literature by extending our knowledge of observed compensation contract designs. Evidence on the mitigating role of non-accounting performance measures in CEO annual bonus contracts on the relation between option compensation and earnings management 
indicates that the performance measures used in annual bonus contracts matter to the CEO. This demonstrates the importance of CEO annual bonus contracts in a time where the CEO's wealth change from the annual bonus has become small relative to the wealth effects provided by the CEO's stock and option portfolio holdings.

The remainder of this chapter is organized as follows. In section $4.2,1$ develop my research hypothesis. In section 4.3-4.5, I discuss my sample, my empirical models and I define the measurement of my dependent and independent variables. In section 4.6, I provide descriptive statistics. In section 4.7, I present the results of the empirical tests, and I conclude in section 4.8 .

\subsection{Theory and hypothesis}

Previous research indicates that CEOs' stock option compensation leads to incentives for earnings management. The idea of these studies rests on two assumptions. First, it assumes that the stock market uses earnings to forecast firm value. Second, it assumes that executives can exploit this phenomenon by manipulating earnings and thereby affecting outsiders' firm value forecasts. For example, executives who intend to exercise options in the near future would have an incentive to manage earnings upward to increase short-term stock prices and thereby boost their personal wealth upon the exercise of the options. Similarly, executives who anticipate to receive a large option award would have an incentive to manage earnings downward to decrease short-term stock prices and thereby lower the options' exercise price on the award date, which simultaneously increases the likelihood that the options end up in the money in the future. Thus, equity-incentive-related earnings management is crucially dependent on market participants' reliance on reported earnings in forming beliefs about firm value.

In addition to accounting information, non-accounting information plays an important role in price-setting. Previous studies indicate that non-accounting performance measures positively impact future accounting-based and marketbased returns (e.g., Ittner \& Larcker, 1998). The importance of non-accounting measures has also precedence in the executive compensation literature. This literature shows that non-accounting performance measures are used in compensation contracts because these measures are leading indicators of future financial performance. Improvements in non-accounting areas such as innovation, quality, or customer satisfaction are not fully captured in accounting numbers. Accordingly, non-accounting measures can supplement accounting measures in CEO annual bonus contracts to further align managerial actions with shareholder's interests. 
If firms gather non-accounting information to reward their executives, then market participants may use the variation in current compensation that is not explained by variation in current accounting measures to infer performance on the non-accounting measures. Following Hayes and Schaefer $(2000,2005), 1$ predict that CEO annual bonus contracts signal the importance of other, nonaccounting information, supplementary to accounting earnings, in making firm value forecasts. When the weight placed on non-accounting measures in CEO bonus contracts increases, there is more information about future performance contained in the payment made to the executive. In that case, market participants can infer these future performance effects by observing the magnitude of bonus payments, which decreases the CEO's incentives for option related earnings management.

The expectation that option related earnings management decreases once the compensation contract includes non-accounting performance measures is not simply due to the fact that the information set available to outsiders increases. More important is that the inclusion of non-accounting measures can act as a disciplining mechanism. Given that bonus payments communicate nonaccounting performance to the stock market, market participants can better evaluate the permanence of current changes in earnings. For example, to the extent that unexpectedly high earnings that result from opportunistic accounting choices do not lead to high bonuses, market participants can infer that these bonuses are thus unwarranted, which effects their beliefs about firm value. Managing earnings is thus less likely to be effective in influencing stock prices, which decreases the incentive for earnings management to affect market assessments of the firm's prospects. Based on the above discussion, I state the following hypothesis:

H1: Greater reliance on non-accounting performance measures in CEO annual bonus contracts decreases the impact of option-based equity incentives on the incidence of earnings management.

\subsection{Data}

The data analyzed in this study come from four sources. CEO compensation data comes from the Standard and Poor's ExecuComp database, accounting data from the Standard and Poor's Compustat database, price data from Datastream, and performance measure data from firms' proxy statements.

My initial sample consists of all firms in ExecuComp without CEO turnover during the period 1998-2002, a period that includes both bull and bear markets. 


\section{CHAPTER 4}

Following previous studies (e.g., Ittner et al., 1997; Said et al., 2003), I use proxy data (DEF 14a) from the EDGAR system ${ }^{27}$ to create a sample of firms where the explicit weights placed on accounting and non-accounting performance measures in the CEO's annual bonus contract are known to the CEO and disclosed on an ex ante basis. To identify firms that use explicit weights, I read the CEO compensation paragraph of each proxy statement, searching for keywords such as "weight", "exclusively", "solely" and "entirely". To identify the use of nonaccounting measures I search for keywords such as "customer satisfaction," "quality," "process improvement," "reengineering," "new product development," "diversity," "market share," "productivity or efficiency," "safety," "innovation," "operational measure or operational performance," and "strategic objectives." I classify performance measures such as "earnings per share," "revenue," "return on assets" and "return on sales" as accounting performance measures. Consistent with previous research (e.g., Burgstahler and Eames, 2003) I filter out utilities (SIC's between 4400 and 5000) and financial institutions (SIC's between 6000 and 6999) because of the distinct production technologies and earnings management incentives in these highly regulated industries. Additionally, following Collins and Hribar (2002), I exclude companies with mergers, acquisitions, or discontinued operations, to reduce measurement error in the estimation of my earnings management proxies. Since the input variables vary between each of my three earnings management measures, my analyses are based on three samples with respectively 717,718 and 700 firm-year observations $(232,232$ and 227 firms). Below, I describe how I operationalize my variables.

\subsection{Measures}

\subsubsection{Definition of earnings management measures}

A number of models have been developed to measure and predict earnings management. Following Aboody et al. (2005), I adopt two models to estimate my earnings management proxies. First, consistent with most prior research (McNichols, 2000), I use a modified version of the Jones model, introduced by Dechow, Sloan and Sweeney (1995). ${ }^{28}$ Second, I employ the Dechow and Dichev (2002) model. Both models use accounting fundamentals to separate accruals into normal (nondiscretionary) and abnormal (discretionary) components. The absolute value of the abnormal component is a proxy for the level of

\footnotetext{
${ }^{27}$ EDGAR data can be found at the following website: http://www.sec.gov/edgar/searchedgar/companysearch.html.

${ }^{28}$ As illustrated in appendix $B$, the modified Jones model yields two earnings management proxies, one based on total accruals and one based on total current accruals.
} 
earnings management. Higher absolute values indicate poorer earnings quality and a greater level of earnings management. Appendix $B$ describes the calculation of my three earnings management proxies (EM proxies) in greater detail.

\subsubsection{Definition of CEO option compensation measures}

To assess the influence of stock option compensation on earnings management, I consider the sensitivity of option values to the price of the underlying stock. As argued, I expect earnings management incentives arising from the level of existing option holdings and grants of new options. With respect to option holdings, managers are expected to influence stock price around the time period in which the options are sold. Since not all existing stock option holdings can be sold, I am careful to distinguish exercisable and unexercisable option holdings. Following Core and Guay (1999), I measure the sensitivity to price of the CEO's exercisable (unexercisable) option holdings as the dollar change (in $\$$ thousands) in the value of the CEO's exercisable (unexercisable) option portfolio holdings for a $1 \%$ change in the stock price. I use the logarithmic transformation of the sensitivity to price measures in my tests. To assess whether managers influence earnings prior to new stock option grants, I compute the same sensitivity to price measure for option awards occurring shortly after the completion of the financial reporting process. ${ }^{29}$

\subsubsection{Definition of the use of non-accounting measures}

I employ two different variables to measure the use and incentive-intensity of non-accounting performance measures in the CEO's annual bonus contract. First, I use the relative weight placed on non-accounting performance measures (PERFMEAS) in the CEO's annual bonus contract, where the weights on accounting and non-accounting measures sum to 100 percent. Second, I create a measure that captures the amount of compensation that is affected by performance on non-accounting performance measures. Bushman et al. (1996) and Ittner et al. (1997) argue that the amount of compensation that is at-risk based on non-accounting measures depends not only on the relative weight placed on these measures, but also on the target bonus amount. This measure is a more comprehensive proxy of the importance of non-accounting information to the board in making both compensation and governance decisions. ${ }^{30}$ Consistent

\footnotetext{
${ }^{29}$ Appendix A describes the option valuation model and sensitivities of individual options to stock price in detail.

${ }^{30}$ Höppe and Moers (2007) provide empirical evidence consistent with the argument that bonus contracts communicate the way in which boards of directors evaluate the CEO and that these evaluations are subsequently used in governance decisions such as CEO termination.
} 
with Ittner et al. (1997), I compute this variable as the percentage of the target bonus amount subject to non-accounting performance to target cash compensation, ${ }^{31}$

$N F C O M P=\left(\frac{T A R G E T \text { BONUS }}{\text { BASE SALARY }+ \text { TARGET BONUS }}\right) *$ PERFMEAS

\subsubsection{Control variables}

To control for firm characteristics that affect managers' incentives to intervene in the financial reporting process, $I$ include a number of additional factors. I use the sensitivity of CEO stock holdings to stock price as a proxy for the level of CEO stock ownership. Following Warfield et al. (1995) I expect that CEO stock ownership aligns managers' incentives with those of shareholders. Therefore, in contrast to option compensation, which creates a focus on short-term stock price orientation, I expect that managerial stock ownership focuses managers' efforts on achieving higher total (long-term) shareholder returns. Thus, higher stock ownership, and a correspondingly higher sensitivity to price of the CEO's stock holdings, is expected to discourage opportunistic reporting of accounting numbers.

Following prior research, I also control for firm size (e.g., Warfield et al., 1995), proxied by the natural logarithm of the firm's market value, and leverage (e.g., Wang, 2005; Cheng and Warfield, 2005), measured by the ratio of longterm debt to total assets. Since there is mixed evidence as to whether managers tend to manage earnings to decrease political costs (proxied by firm size) or to avoid debt covenant violation (proxied by leverage), I make no prediction for the sign of the coefficients of these variables.

Consistent with Richardson et al. (2002), I use the book-to-market ratio as an inverse indicator for a firm's growth prospects/opportunities. Prior research documents that the stock price of growth firms (i.e. low book-to-market firms) is particularly sensitive to deviations from earnings expectations (Skinner and

\footnotetext{
${ }^{31}$ Proxy statements did not provide target bonus amounts for all the firms in the sample. I follow Ittner et al. (1997) to assign target bonus values to these firms. In those instances in which minimum and maximum bonuses were given in the proxy, the average of the minimum and maximum was used as the target. If only the maximum was provided, the target was defined as half the maximum bonus. For the remaining firms, 1 imputed the target bonus by first regressing the available target bonus amounts on industry indicators and firm sales. The coefficients from this model were then used to impute the missing bonus targets. This imputation was used for 55 percent of the sample (compared to 39 percent reported by Ittner et al. (1997)).
} 
Sloan, 2002). Growth firms are thus expected to be more likely to make strategic accounting choices to deliver the anticipated growth in earnings.

Similar in spirit to the approach by Barton and Simko (2002) and Cheng and Warfield (2005), I use the beginning-of-period net operating assets (defined as shareholders' equity less cash and marketable securities, plus total debt) relative to sales as a proxy for managers' previous income-increasing reporting choices. To the extent that the level of net operating assets captures previous optimism in financial reporting, I expect that firms with high net operating assets encounter a lack of flexibility in managing earnings upward in the current year. To the extent that prior optimistic accounting choices reduce the overall likelihood of earnings management, I predict that firms with large net operating assets in the previous year are associated with smaller abnormal accruals.

Table 4.1 Variable definitions

Variable name
Variable description

I employ three earnings management measures related to the unsigned value of a firm's discretionary accruals defined in Aboody et al. (2005). Two proxies are based on the modified Jones' model (Dechow, Sloan, and Sweeney, 1995) and one is based on the Dechow and Dichev (2002) model. The text below describes the three measures in greater detail.

PERFMEAS

The relative weights placed on non-accounting performance measures in CEO annual bonus contracts during year $t$.

NFCOMP

The percentage of short-term compensation based on non- accounting performance measures in CEO annual bonus contracts during year $t$. NFCOMP $=$ (Target Bonus)/(Salary + Target Bonus $)$ * PERFMEAS

STP exercisable options Sensitivity to price of the CEO's exercisable option holdings: the change in the dollar value of the CEO's exercisable option holdings for a $1 \%$ change in the stock price.

STP unexercisable options Sensitivity to price of the CEO's unexercisable option holdings: the change in the dollar value of the CEO's unexercisable option holdings for a $1 \%$ change in the stock price.

STP option grant

Sensitivity to price of the CEO's option grant: the change in the dollar value of the CEO's option grant for a $1 \%$ change in the stock price.

STP stock Sensitivity to price of the CEO's stock holdings: the change in the dollar value of the CEO's stock holdings for a $1 \%$ change in the stock price.

Firm size

The firm's market value at the end of fiscal year $t$.

Leverage

Book-to-market

Ratio of long-term debt to total assets, both at the end of fiscal year $t$. Inverse measure of growth, calculated as the ratio of the book value of shareholders' equity to the market value of common stock, both measured at the end of fiscal year $t$.

Net operating assets

Ratio of (Shareholders' equity - cash and marketable securities + total debt) all at the end of fiscal year $t-1$ scaled by sales for fiscal year $t-1$. 1 - ratio of gross PPE to total assets at the end of fiscal year $t$.

Implicit claims $\begin{aligned} & \text { Accounting earnings informa- Fisher z-scores for the correlations between accounting returns } \\ & \text { tiveness } \\ & \text { (Return on Assets/Return on Equity/Return on Sales) and stock }\end{aligned}$ tiveness market returns over the three years prior to the proxy data.

Additionally, consistent with Bowen et al. (1995), I use a firm's labor intensity, measured as one minus the ratio of gross property, plant and equipment to firm size, as a proxy for the extent to which firms depend on implicit claims with their 
employees. To the extent that a firm's financial condition affects employees' image of the firms' ability to fulfill these implicit commitments, I predict that firms with more implicit claims are more likely to manage reported earnings.

Since different industries are confronted with varying amounts of judgment in the financial reporting process, I also include two-digit SIC industry dummy variables to control for these differences. Finally, I include year indicator variables to control for potential year specific effects. Table 4.1 summarizes my variable definitions.

\subsection{Research methodology}

To examine whether the use of non-accounting performance measures in CEO annual bonus contracts mitigates option-driven earnings management, I estimate the following ordinary least square regression (for variable definitions see table 4.1): ${ }^{32}$

$\mid E M$ proxy $_{i} \mid=\alpha_{0}+\alpha^{P M}$ Performance measures proxy ${ }_{i}+$

$\alpha^{E Q}$ Option based equity incentives proxy $_{i}+$

$\alpha^{E Q_{-}{ }^{P M}}$ Option based equity incentives proxy $_{i} \times$

Performance measures proxy ${ }_{i}+\alpha^{F}$ FIRM $_{i}+\varepsilon_{i}$

Where:

$F I R M_{i}=$ a vector of firm is characteristics (including industry dummy variables and year indicator variables) that are expected to affect managers' reporting decisions. All variables are defined in table

4.1.

and $\alpha^{F}$ is a vector of coefficients.

The dependent variable in this regression represents my earnings management proxies (defined in section 4.4.1). Following Warfield et al. (1995), I use absolute values because my hypothesis focuses on earnings management intensity, which involves the magnitude and not the direction of adjusted reported numbers.

Conceptually, my hypothesis implies that the rate of change in the level of earnings management associated with a given change in the level of optionbased equity incentives is not a constant, but rather varies with the use of nonaccounting performance measures in CEO annual bonus contracts. A statistical

${ }^{32}$ To deal with multiple observations for a given firm, I specify my empirical tests using Rogers standard errors (Rogers, 1993; Petersen, 2005). 
representation consistent with this hypothesis implies the existence of a significant two-way interaction between the two independent variables. In order to determine the presence of a two-way interaction, it is necessary to partial out all of the variance associated with the two main effects of the two variables that are used in forming the cross-product term.

The coefficients of the main effects represent the effect of one variable when the value of the other variable is zero. In this case this means that the coefficient of the main effect $d^{M M}$ represents the effect of the Performance measures proxy when the value of the Option based equity incentives proxy is zero (this only occurs for the incentive-intensity of anticipated option grants). A more meaningful interpretation applies to $\alpha^{E Q}$, which measures the effect of the Option based equity incentives proxy on earnings management for CEOs with bonus contracts completely based on accounting performance measures. Finally, the coefficient of the interaction term, $\alpha^{E Q_{-} P M}$, captures the extent to which the use of nonaccounting performance measures in CEO annual bonus contracts moderates the relationship between option-based equity incentives and earnings management. Since I expect that the use of non-accounting performance measures in CEO annual bonus contracts mitigates option-driven earnings management, I expect the coefficient of the interaction term to be negative.

A potential limitation not addressed in my regression specification (4.1) concerns my moderator variable. To the extent that my moderator variable (the reliance on non-accounting performance measures in CEO annual bonus contracts) captures the inverse of the informativeness of accounting earnings in explaining stock returns, my results reflect that earnings management is a joint function of earnings informativeness and equity incentives rather than the choice of performance measures in the annual bonus contract and equity incentives. To address this issue, I estimate a second model including a proxy for the informativeness of accounting earnings. ${ }^{33}$ Since 1 aim to control for the moderating role of the informativess of accounting earnings on the relationship between optionbased equity incentives and earnings management my second model includes both an additional main effect ( $\alpha^{E l}$ Accounting earnings informativeness) and an additional interaction term ( $\alpha^{\text {EQ_El }}$ Option based equity incentives proxy * Accounting earnings informativeness).

While my model includes this interaction in order to reduce measurement error in my moderator variable of interest (the reliance on non-accounting performance measures in CEO annual bonus contracts), a priori I also expect the coefficient of this second interaction term to be positive for both the incentive-

${ }^{33}$ I define informativeness as the Fisher z-scores for the correlations between accounting returns (Return on Assets/Return on Equity/Return on Sales) and stock market returns over the three years prior to the proxy data. 
intensity of exercisable stock option holdings and anticipated option grants, i.e., I expect the relationship between option-based equity incentives and earnings management intensity to be stronger in firms with more informative earnings. My second model is summarized as:

$\mid E M$ proxy $_{t} \mid=\alpha_{0}+\alpha^{p_{M}}$ Performance measures proxy +

$\alpha^{E Q}$ Option based equity incentives proxy +

$\alpha^{E Q_{-} P M}$ Option based equity incentives proxy, $\times$

Performance measures proxy, +

$\alpha^{E I}$ Accounting earnings informativeness $s_{i}$

$\alpha^{E Q}{ }_{-}{ }^{E I}$ Option based equity incentives proxy $\times$

Accounting earnings informativeness, $+\alpha^{F} F I R M_{1}+\varepsilon_{1}$

Where:

$F I R M_{i}=$ a vector of firm is characteristics (including industry dummy variables and year indicator variables) that are expected to affect managers' reporting decisions. All variables are defined in table 4.1.

and $\alpha^{F}$ is a vector of coefficients.

\subsection{Descriptive analysis}

Table 4.2 reports summary statistics on the earnings management measures used in my analyses. I estimate each of the three earnings management measures annually over the years 1998-2002. This yields 717 firm-year observations for $E M 1,718$ firm-year observations for EM2, and 700 firm-year observations for EM3.

Table 4.2 Summary statistics on earnings management measures

\begin{tabular}{lcccc}
\multicolumn{5}{l}{ Panel A: Descriptive statistics } \\
\hline & $N$ & Mean & Median & $\begin{array}{c}\text { Inter-Quartile } \\
\text { Range }\end{array}$ \\
EM1 & 717 & 0.046 & 0.033 & 0.046 \\
EM2 & 718 & 0.040 & 0.026 & 0.041 \\
EM3 & 700 & 0.039 & 0.027 & 0.040 \\
\hline
\end{tabular}

Panel B: Correlation matrix, Pearson below diagonal and Spearman above

\begin{tabular}{lccc}
\hline & EM1 & EM2 & EM3 \\
EM1 & 1.000 & 0.686 & 0.416 \\
EM2 & 0.868 & 1.000 & 0.532 \\
EM3 & 0.637 & 0.702 & 1.000 \\
\hline
\end{tabular}

Notes:

Variables are defined in table 4.1.

\# Pearson (Spearman) correlation coefficients are all significant at the $1 \%$ level (two-tailed). 
Table 4.2, panel A presents mean and median values for my earnings management measures in a range of 0.026 to 0.046 . Correlation coefficients reported in panel $B$ of table 4.2 show substantial overlap in the information contained in each of my earnings management measures. The two measures based on the modified Jones model (EM1, EM2) are highly correlated, with a Pearson correlation of 0.87 (Spearman correlation coefficient at 0.69 ). Correlations between these measures $(E M 1, E M 2)$ and the measure derived from the Dechow and Dichev approach (EM3) are lower. I find Pearson (Spearman) correlation coefficients of $0.64(0.42)$ between EM1 and EM3 and of $0.70(0.53)$ between EM2 and EM3. All correlation coefficients show that my EM proxies capture similar information.

Table 4.3 Summary statistics of the factors that affect managers' reporting choice

\begin{tabular}{lrrrrr}
\hline Variable & Mean & Std. Dev. & Q1 & Median & Q3 \\
\hline PERFMEAS & 0.067 & 0.194 & 0 & 0 & 0 \\
NFCOMP & 0.032 & 0.099 & 0 & 0 & 0 \\
STP exercisable options & 152,947 & 415,343 & 11,616 & 42,878 & 136,577 \\
STP unexercisable options & 154,364 & 273,850 & 17,409 & 58,588 & 150,632 \\
STP option grant & 59,158 & 172,139 & 0 & 14,186 & 48,637 \\
STP stock & 782,967 & $2,341,327$ & 26,434 & 106,237 & 401,446 \\
Firm size (in thousand \$) & $3,491,872$ & $7,913,207$ & 406,470 & $1,081,379$ & $2,801,536$ \\
Leverage & 0.183 & 0.149 & 0.031 & 0.174 & 0.289 \\
Book-to-market & 0.559 & 0.427 & 0.271 & 0.447 & 0.699 \\
Net operating assets & 0.606 & 0.517 & 0.288 & 0.463 & 0.726 \\
Implicit claims & 0.413 & 0.350 & 0.189 & 0.485 & 0.689 \\
Correlation (Fisher z) between annual & & & & & \\
$\quad$ market returns and ROA & 0.193 & 1.510 & -0.701 & 0.159 & 1.038 \\
Correlation (Fisher z) between annual & & & & & \\
$\quad$ market returns and ROE & 0.242 & 1.625 & -0.646 & 0.215 & 1.134 \\
$\quad$ Correlation (Fisher z) between annual & & & & & \\
$\quad$ market returns and ROS & 0.192 & 1.448 & -0.679 & 0.161 & 1.025 \\
\hline Notes: & & & & &
\end{tabular}

Notes:

Variables are defined in Table 4.1.

Table 4.3 provides descriptive statistics for all explanatory variables. ${ }^{34}$ As indicated, I consider two different variables to measure the use and incentiveintensity of non-accounting performance measures in the CEO's annual bonus contract. My first measure, PERFMEAS, shows that the mean weight placed on non-accounting performance in CEO annual bonus contracts is $6.7 \%$ across all 718 firm-year observations and $44.8 \%$ in the 107 firm-year observations with non-zero weights on non-accounting measures (not tabulated). The mean value

\footnotetext{
34 Table 4.3 reports descriptive statistics based on the 718 firm-year observations in the EM2 sample. To mitigate the influence of outliers, each continuous explanatory variable used in my analyses (except for the variables that measure the reliance on non-accounting performance measures in the CEO's annual bonus contract) is winsorized at the $1 \%$ level of the distribution (e.g., Core and Guay, 1999).
} 


\section{CHAPTER 4}

for NFCOMP, the percentage of targeted cash compensation that is affected by performance on non-accounting performance measures, equals $3.2 \%$ in the total sample and $21.7 \%$ in the 107 firm-year observations with non-zero weights on non-accounting measures (not tabulated).

The other compensation structure variables relate to the incentive-intensity of equity incentives. The median (mean) change in CEO wealth from a $1 \%$ change in stock price ranges from $\$ 42,878(\$ 152,947)$ for exercisable option holdings to $\$ 14,186(\$ 59,158)$ for newly granted options. The level of CEO stock holdings is the most stock price sensitive component of the CEO's portfolio equity incentives. The median (mean) change in the CEO's stock holdings from a $1 \%$ change in stock price is $\$ 106,237$ ( $\$ 782,967)$. To reduce the effect of large observations within these equity incentive measures, I use logarithmic transformations in my tests.

The firm characteristics used in my tests show substantial variation. On average, my sample firms have a market capitalization of almost $\$ 3.5$ billion and the book value of their equity equals a bit more than half this amount. Around $18 \%$ of their assets are financed through long-term debt, they report net operating assets as a percentage of sales at approximately $60 \%$, and $41 \%$ of their total assets consists of other assets than property plant and equipment.

Table 4.4 Correlation coefficients between the factors that affect managers' reporting choice

\begin{tabular}{|c|c|c|c|c|c|c|c|c|c|c|c|c|}
\hline Variable & 1 & 2 & 3 & $\overline{4}$ & 5 & $\overline{6}$ & 7 & 8 & 9 & 10 & $\overline{11}$ & 12 \\
\hline 1. PERFMEAS & 1.00 & 1.00 & 0.15 & 0.13 & 0.12 & -0.02 & 0.09 & 0.03 & -0.05 & 0.13 & 0.05 & -0.04 \\
\hline 2. NFCOMP & 0.98 & 1.00 & 0.15 & 0.13 & 0.12 & -0.02 & 0.09 & 0.03 & -0.05 & 0.13 & 0.04 & -0.04 \\
\hline 3. Log (STP exercisable options) & 0.14 & 0.13 & 1.00 & 0.70 & 0.41 & 0.26 & 0.53 & 0.10 & -0.29 & 0.09 & 0.10 & -0.09 \\
\hline 4. Log (STP unexercisable options) & 0.17 & 0.17 & 0.69 & 1.00 & 0.48 & 0.24 & 0.59 & 0.08 & -0.38 & 0.03 & 0.15 & -0.05 \\
\hline 5. Log (STP option grant) & 0.18 & 0.18 & 0.38 & 0.47 & 1.00 & -0.01 & 0.35 & 0.07 & -0.26 & 0.01 & 0.10 & -0.04 \\
\hline 6. Log (STP stock) & 0.00 & -0.01 & 0.18 & 0.13 & -0.03 & 1.00 & 0.46 & -0.07 & -0.30 & -0.04 & 0.13 & -0.07 \\
\hline 7. Log (Firm size) & 0.11 & 0.10 & 0.50 & 0.52 & 0.32 & 0.46 & 1.00 & 0.09 & -0.60 & 0.15 & 0.04 & -0.10 \\
\hline 8. Leverage & -0.02 & -0.04 & 0.09 & 0.10 & 0.05 & -0.06 & 0.07 & 1.00 & 0.20 & 0.38 & -0.31 & 0.03 \\
\hline 9. Book-to-market & -0.10 & -0.10 & -0.29 & -0.29 & -0.25 & -0.28 & -0.59 & 0.18 & 1.00 & 0.20 & -0.16 & 0.09 \\
\hline 10. Net operating assets & 0.11 & 0.11 & 0.01 & -0.01 & 0.02 & -0.06 & 0.08 & 0.39 & 0.15 & 1.00 & -0.25 & 0.01 \\
\hline 11. Implicit claims & 0.09 & 0.09 & 0.13 & 0.13 & 0.09 & 0.14 & 0.06 & -0.29 & -0.16 & -0.26 & 1.00 & -0.02 \\
\hline $\begin{array}{l}\text { 12. Accounting earnings informa- } \\
\text { tiveness }\end{array}$ & -0.04 & -0.04 & -0.03 & -0.03 & -0.01 & -0.05 & -0.10 & 0.06 & 0.08 & 0.00 & -0.04 & 1.00 \\
\hline
\end{tabular}

Table 4.4 presents the Pearson and Spearman correlations between the independent variables used in my analyses. The significant positive correlation between most of the equity incentive measures indicates that firms use a combination of options and stock to tie CEO wealth to company stock price performance. Table 4.4 further shows that the reliance on non-accounting performance measures in CEO annual bonus contracts is positively correlated with the incen- 
tive-intensity of option-based equity incentives. ${ }^{35}$ Additionally, the incentiveintensity of option-based equity incentives is larger for CEOs in bigger, more indebted, growth firms (i.e. firms with higher market capitalizations, higher leverage and lower book-to-market ratios).

\subsection{Results}

The results in table 4.5 are from the ordinary least squares regressions using the relative weight assigned to non-accounting performance measures in the CEO's annual bonus contract as proxy for the reliance on non-accounting performance measures. Three models are presented, each with an alternative earnings management proxy EM1, EM2, EM3 (defined in section 4.4.1).

My main results are related to the effect of the use of non-accounting performance measures on the relation between anticipated option grants and earnings management. The coefficient on STP option grant tests the relation between the incentive-intensity of newly granted options and the absolute value of abnormal accruals for managers with accounting based bonus contracts. In line with previous research (Baker et al., 2003), I find evidence that the incentive-intensity of anticipated option awards influences managers' accounting choices. As indicated by the significantly positive coefficient on STP option grant, managers expecting to receive a large option award and a bonus based on accounting information appear to use discretionary accruals in an attempt to increase the value of their option awards.

My results extend previous research by documenting that this managerial intervention in the financial reporting process is restricted to situations in which CEO bonus contracts are solely based on accounting information. More specifically, the significantly negative coefficient for the interaction STP option grant * PERFMEAS in two of the three earnings management models shows that managers with higher levels of anticipated option awards report significantly lower abnormal accruals in the presence of non-accounting measures in the annual bonus contract versus the absence. This result provides support for the view that the use of non-accounting performance measures in CEO annual bonus contracts mitigates option-driven earnings management. It reflects that managers' incentives to intervene in the financial reporting process to influence the exercise price of their option awards dampen in situations where the market's valuation of the firm is based on accounting as well as non-accounting

\footnotetext{
${ }^{35}$ Chapter 3 finds a negative relation between the reliance on non-accounting performance measures in CEO annual bonus contracts and the price sensitivities of managerial equity portfolio holdings. Unlike chapter 3 , the analyses presented here do not consider the portfolio of equity holdings as whole. Thus, one should be careful in comparing my results with those in chapter 3.
} 
performance Overall, this evidence supports the moderating effect of the use of non-accounting performance measures in CEO annual bonus contracts on the link between anticipated option compensation and annual accrual choices, confirming my hypothesis.

Table 4.5 Regressions of earnings management measures on the reliance on non-accounting performance measures in CEO annual bonus contracts (PERFMEAS), stock option holdings, stock option compensation and other firm characteristics that affect managers' reporting choices

\begin{tabular}{|c|c|c|c|c|}
\hline \multirow[b]{2}{*}{ Independent Variable } & \multirow[b]{2}{*}{$\begin{array}{c}\text { Expected } \\
\text { sign }\end{array}$} & \multicolumn{3}{|c|}{ Coefficient Estimate } \\
\hline & & EM1 & EM2 & EM3 \\
\hline PERFMEAS & $?$ & $\begin{array}{l}-0.0122 \\
(-0.18)\end{array}$ & $\begin{array}{c}0.0239 \\
(0.38)\end{array}$ & $\begin{array}{l}0.0130 \\
(0.37)\end{array}$ \\
\hline Log (STP exercisable options) & + & $\begin{array}{l}-0.0015 \\
(-1.22)\end{array}$ & $\begin{array}{l}-0.0021 \\
(-1.73)^{\star}\end{array}$ & $\begin{array}{l}-0.0007 \\
(-0.71)\end{array}$ \\
\hline Log (STP exercisable options) * PERFMEAS & - & $\begin{array}{l}-0.0036 \\
(-0.33)\end{array}$ & $\begin{array}{l}-0.0067 \\
(-0.59)\end{array}$ & $\begin{array}{l}-0.0106 \\
(-2.03)^{\star \star}\end{array}$ \\
\hline Log (STP unexercisable options) & $?$ & $\begin{array}{l}-0.0012 \\
(-0.76)\end{array}$ & $\begin{array}{l}-0.0004 \\
(-0.26)\end{array}$ & $\begin{array}{l}-0.0013 \\
(-1.03)\end{array}$ \\
\hline Log (STP unexercisable options) * PERFMEAS & $?$ & $\begin{array}{l}0.0109 \\
(0.84)\end{array}$ & $\begin{array}{c}0.0111 \\
(1.02)\end{array}$ & $\begin{array}{l}0.0139^{*} \\
(1.80)\end{array}$ \\
\hline Log (STP option grant) & + & $\begin{array}{l}0.0028^{\star *} \\
(2.38)\end{array}$ & $\begin{array}{l}0.0029^{* * *} \\
(3.01)\end{array}$ & $\begin{array}{l}0.0031^{\star * \star} \\
(3.46)\end{array}$ \\
\hline Log (STP option grant) * PERFMEAS & - & $\begin{array}{l}-0.0065 \\
(-0.97)\end{array}$ & $\begin{array}{l}-0.0118^{*} \\
(-1.81)\end{array}$ & $\begin{array}{l}-0.0104^{\star \star \star} \\
(-2.91)\end{array}$ \\
\hline Log (STP stock) & - & $\begin{array}{l}-0.0018^{\dagger} \\
(-1.57)\end{array}$ & $\begin{array}{l}-0.0022^{*} \\
(-1.87)\end{array}$ & $\begin{array}{l}-0.0012 \\
(-1.33)\end{array}$ \\
\hline Log (Firm size) & $?$ & $\begin{array}{l}-0.0042^{\dagger} \\
(-1.60)\end{array}$ & $\begin{array}{l}-0.0024 \\
(-0.99)\end{array}$ & $\begin{array}{l}-0.0032^{\star} \\
(-1.80)\end{array}$ \\
\hline Leverage & $?$ & $\begin{array}{l}-0.0230^{*} \\
(-1.76)\end{array}$ & $\begin{array}{l}-0.0250^{\star \star} \\
(-2.18)\end{array}$ & $\begin{array}{l}-0.0229^{\star \star} \\
(-2.31)\end{array}$ \\
\hline Book-to-market & - & $\begin{array}{l}-0.0053 \\
(-0.80)\end{array}$ & $\begin{array}{l}-0.0024 \\
(-0.43)\end{array}$ & $\begin{array}{l}-0.0010 \\
(-0.23)\end{array}$ \\
\hline Net operating assets & - & $\begin{array}{l}-0.0100^{\star *} \\
(-2.07)\end{array}$ & $\begin{array}{l}-0.0122^{\text {***}} \\
(-2.55)\end{array}$ & $\begin{array}{l}-0.0084^{\star \star \star} \\
(-2.68)\end{array}$ \\
\hline Implicit claims & + & $\begin{array}{l}0.0189^{\star \star \star} \\
(2.59)\end{array}$ & $\begin{array}{l}0.0223^{\star \star \star} \\
(3.19)\end{array}$ & $\begin{array}{l}0.0169^{\star \star \star} \\
(3.17)\end{array}$ \\
\hline
\end{tabular}

\begin{tabular}{lccc}
\hline $\mathrm{N}$ & 717 & 718 & 700 \\
\hline Adjusted $\mathrm{R}^{2}$ & $7.8 \%$ & $9.0 \%$ & $11.3 \%$ \\
\hline
\end{tabular}

Notes:

T-statistics (in parentheses) are based on Rogers standard errors. Coefficients on an intercept, 5 industry indicator variables and 4-year indicator variables are not reported. Variables are defined in table 4.1.

${ }_{\star \star \star \star},{ }^{* \star},{ }^{\star}{ }^{\dagger}$ denotes statistical significance at the $0.01,0.05,0.10$ and 0.15 level (two-tailed).

In contrast, the results provide hardly any support for my expectations on the incentive-intensity of exercisable stock option holdings. The coefficients on STP exercisable options and STP exercisable options * PERFMEAS are both insignificant in two out of three models, indicating that, on average, my sample firms do not show a systematic relation between the incentive-intensity of exercisable 
options and earnings management, neither in absence, nor in presence of bonus contracts based on non-accounting measures of performance. This can be explained by the idea that earnings management to influence the value of exercisable options is likely to take place over a longer time span, whereas earnings management to influence the value of option grants should have a stock price effect at the grant date only. Additionally, the value of option grants is positively influenced by a decrease in stock price, which is more easily achieved than an upward stock price effect, which is necessary to increase the value of the CEO's exercisable option holdings.

Results for the control variables are generally consistent with predictions and prior literature. Specifically, results reveal that the magnitude of accounting adjustments is inversely related to the incentive-intensity of the CEO's stock holdings (STP stock) in two out of three models. In line with the incentive alignment argument provided in Warfield et al. (1995), this indicates that high CEO equity ownership discourages opportunistic earnings management behavior. The coefficients on Firm size and Leverage are negative and significant, showing that large firms and firms with more debt have lower abnormal accruals. These findings contrast expectations from positive accounting theory, but are consistent with studies from e.g., Frankel, Johnson, and Nelson (2002) and Cheng and Warfield (2005). The coefficient on Book-to-market does not differ significantly from zero even though it is predicted to be negative. Warfield et al. (1995) also fail to find evidence of a relation between a firm's growth prospects and accrual adjustments. Consistent with Barton and Simko (2002), the level of net operating assets at the beginning of the year under investigation is inversely related to the incidence of earnings management, reflecting that firms with high net operating assets encounter a lack of flexibility in managing earnings. Finally, as predicted, firms with more implicit claims exhibit more strategic accounting choice behavior.

To further investigate whether the relation between option-based equity incentives and earnings management depends on the composition of CEO annual bonus contracts, I replicate the analyses from table 4.5 using my alternative measure (NFCOMP) for the reliance on non-accounting performance measures in CEO annual bonus contracts. Table 4.6 reports the additional tests.

The results for the NFCOMP measure, which takes into account the amount of targeted cash compensation that is at risk based on non-accounting performance measures, lead to similar inferences. This shows that, all else equal, the importance of non-accounting information in CEO annual bonus contracts has an inverse effect on managers' discretionary accrual choices to influence the value of their anticipated stock option awards. This supports my argument that bonus contracts based on non-accounting measures act as a disciplining mechanism and constrains option-driven earnings management. 
Table 4.6 Regressions of earnings management measures on the reliance on non-accounting performance measures in CEO annual bonus contracts (NFCOMP), stock option holdings, stock option compensation and other firm characteristics that affect managers' reporting choices

\begin{tabular}{|c|c|c|c|c|}
\hline \multirow[b]{2}{*}{ Independent Variable } & \multirow[b]{2}{*}{$\begin{array}{c}\text { Expected } \\
\text { sign } \\
\end{array}$} & \multicolumn{3}{|c|}{ Coefficient Estimate } \\
\hline & & EM1 & EM2 & EM3 \\
\hline NFCOMP & $?$ & $\begin{array}{l}-0.0265 \\
(-0.26)\end{array}$ & $\begin{array}{c}0.0252 \\
(0.28)\end{array}$ & $\begin{array}{l}0.0124 \\
(0.22)\end{array}$ \\
\hline Log (STP exercisable options) & + & $\begin{array}{l}-0.0016 \\
(-1.26)\end{array}$ & $\begin{array}{l}-0.0022^{\star} \\
(-1.78)\end{array}$ & $\begin{array}{l}-0.0007 \\
(-0.72)\end{array}$ \\
\hline Log (STP exercisable options) * NFCOMP & - & $\begin{array}{l}-0.0020 \\
(-0.14)\end{array}$ & $\begin{array}{l}-0.0060 \\
(-0.45)\end{array}$ & $\begin{array}{l}-0.0189^{\star \star} \\
(-2.45)\end{array}$ \\
\hline Log (STP unexercisable options) & $?$ & $\begin{array}{l}-0.0009 \\
(-0.56)\end{array}$ & $\begin{array}{l}-0.0001 \\
(-0.07)\end{array}$ & $\begin{array}{l}-0.0012 \\
(-0.97)\end{array}$ \\
\hline Log (STP unexercisable options) * NFCOMP & $?$ & $\begin{array}{l}0.0089 \\
(0.48)\end{array}$ & $\begin{array}{l}0.0126 \\
(0.77)\end{array}$ & $\begin{array}{l}0.0257^{\star * *} \\
(2.09)\end{array}$ \\
\hline Log (STP option grant) & + & $\begin{array}{l}0.0027^{\star *} \\
(2.34)\end{array}$ & $\begin{array}{l}0.0028^{* * *} \\
(2.93)\end{array}$ & $\begin{array}{l}0.0031^{* * *} \\
(3.45)\end{array}$ \\
\hline Log (STP option grant) ${ }^{*}$ NFCOMP & - & $\begin{array}{l}-0.0061 \\
(-0.59)\end{array}$ & $\begin{array}{l}-0.0174^{t} \\
(-1.62)\end{array}$ & $\begin{array}{l}-0.0186^{\star \star \star \star} \\
(-3.18)\end{array}$ \\
\hline $\log$ (STP stock) & - & $\begin{array}{l}-0.0019^{\dagger} \\
(-1.60)\end{array}$ & $\begin{array}{l}-0.0022^{*} \\
(-1.87)\end{array}$ & $\begin{array}{l}-0.0012 \\
(-1.33)\end{array}$ \\
\hline Log (Firm size) & $?$ & $\begin{array}{l}-0.0042^{\dagger} \\
(-1.59)\end{array}$ & $\begin{array}{l}-0.0024 \\
(-1.01)\end{array}$ & $\begin{array}{l}-0.0033^{*} \\
(-1.85)\end{array}$ \\
\hline Leverage & $?$ & $\begin{array}{l}-0.0243^{*} \\
(-1.84)\end{array}$ & $\begin{array}{l}-0.0259^{\star *} \\
(-2.27)\end{array}$ & $\begin{array}{l}-0.0233^{\star \star} \\
(-2.36)\end{array}$ \\
\hline Book-to-market & - & $\begin{array}{l}-0.0054 \\
(-0.82)\end{array}$ & $\begin{array}{l}-0.0025 \\
(-0.44)\end{array}$ & $\begin{array}{l}-0.0011 \\
(-0.25)\end{array}$ \\
\hline Net operating assets & - & $\begin{array}{l}-0.0094^{* \star} \\
(-2.00)\end{array}$ & $\begin{array}{l}-0.0118^{\star \star \star} \\
(-2.54)\end{array}$ & $\begin{array}{l}-0.0081^{\star \star \star} \\
(-2.62)\end{array}$ \\
\hline Implicit claims & + & $\begin{array}{l}0.0193^{\star \star \star} \\
(2.61)\end{array}$ & $\begin{array}{l}0.0226^{\star \star \star} \\
(3.19)\end{array}$ & $\begin{array}{l}0.0170^{\star * *} \\
(3.18)\end{array}$ \\
\hline
\end{tabular}

\begin{tabular}{llll}
\hline $\mathrm{N}$ & 717 & 718 & 700 \\
\hline Adjusted R & $7.8 \%$ & $8.8 \%$ & $11.3 \%$ \\
\hline
\end{tabular}

Notes:

T-statistics (in parentheses) are based on Rogers standard errors. Coefficients on an intercept, 5 industry indicator variables and 4-year indicator variables are not reported. Variables are defined in table 4.1.

${ }_{* \star * * * *}^{* *},{ }^{\dagger}$ denotes statistical significance at the $0.01,0.05,0.10$ and 0.15 level (two-tailed).

Consistent with table 4.5 , the results in table 4.6 provide hardly any support for my expectation that earnings management is a joint function of the incentiveintensity of exercisable option holdings and the use of non-accounting performance measures in annual bonus contracts. Likewise, results on the control variables do not deviate from those in table 4.5.

The evidence that the reliance on non-accounting performance measures mitigates option-driven earnings management is consistent with my notion that managers' ability to influence stock prices by adjusting reported performance decreases in situations where market participants (indirectly) observe both public accounting performance and non-public non-accounting performance. At the 
same time, managers' incentives to manage reported earnings are likely to vary with the informativeness of earnings in explaining stock returns. To the extent that accounting numbers that are less informative in measuring economic performance also fail to measure managerial effort, firms with uninformative earnings are more likely to use non-accounting measures in annual bonus contracts. It is thus possible that the use of non-accounting performance measures in CEO annual bonus contracts reflects difficulties of accounting numbers to measure economic performance. To assess the robustness of my results to this possible correlated omitted variable problem, I conduct additional analyses including a measure of the informativeness of accounting earnings (defined in table 4.1 and section 4.5).

Tables 4.7 and 4.8 report regression results for both specifications of my moderator variable (PERFMEAS and NFCOMP) when earnings informativeness is added to my model.

Coefficients of the interactions between option-based equity incentives and accounting earnings informativeness are insignificant in eight out of nine instances in both table 4.7 and 4.8. The only instance in which earnings informativeness and option-based equity incentives jointly affect earnings management yields results in contrast to expectations. More specifically, the significantly negative coefficient for the interaction STP exercisable options * Accounting earnings informativeness shows that managers with more price sensitive exercisable option holdings in firms with informative earnings report significantly lower abnormal accruals than managers with similar exercisable option holdings in firms with less informative earnings. The coefficients and statistical significance of my original test and control variables are comparable with those reported in tables 4.5 and 4.6. Thus, my results are both qualitatively and quantitatively unchanged after controlling for earnings informativeness. ${ }^{36}$

\footnotetext{
${ }^{36} \mathrm{I}$ also estimate my models using signed earnings management measures as a dependent variable. Using one-sided tests in those instances in which I have expectations, the results of these analyses (not tabulated) are similar to those presented here. More specifically, for signed estimates of EM1 and EM2, these analyses show that CEOs with non-accounting performance measures and large option grants report significantly higher discretionary accruals than similar CEOs whose annual bonus does not depend on non-accounting performance measures. In addition, results for signed estimates of EM3 show that CEOs with non-accounting performance measures and large exercisable option holdings report significantly lower discretionary accruals than similar CEOs not having non-accounting performance measures in their annual bonus contract. These results indicate that non-accounting performance measures discipline option-driven earnings management.
} 
CHAPTER 4

Table 4.7 Regressions of earnings management measures on the reliance on non-accounting performance measures in CEO annual bonus contracts (PERFMEAS), stock option holdings, stock option compensation and other firm characteristics that affect managers' reporting choices

\begin{tabular}{|c|c|c|c|c|}
\hline \multirow[b]{2}{*}{ Independent Variable } & \multirow[b]{2}{*}{$\begin{array}{l}\text { Expected } \\
\text { sign }\end{array}$} & \multicolumn{3}{|c|}{ Coefficient Estimate } \\
\hline & & EM1 & EM2 & EM3 \\
\hline PERFMEAS & $?$ & $\begin{array}{l}-0.0088 \\
(-0.13)\end{array}$ & $\begin{array}{l}0.0257 \\
(0.41)\end{array}$ & $\begin{array}{l}0.0144 \\
(0.41)\end{array}$ \\
\hline Log (STP exercisable options) & + & $\begin{array}{l}-0.0013 \\
(-0.99)\end{array}$ & $\begin{array}{l}-0.0022^{*} \\
(-1.67)\end{array}$ & $\begin{array}{l}-0.0008 \\
(-0.78)\end{array}$ \\
\hline Log (STP exercisable options) * PERFMEAS & - & $\begin{array}{l}-0.0039 \\
(-0.37)\end{array}$ & $\begin{array}{l}-0.0068 \\
(-0.60)\end{array}$ & $\begin{array}{l}-0.0105^{*} \\
(-2.01)\end{array}$ \\
\hline Log (STP unexercisable options) & $?$ & $\begin{array}{l}-0.0017 \\
(-1.07)\end{array}$ & $\begin{array}{l}-0.0004 \\
(-0.29)\end{array}$ & $\begin{array}{l}-0.0013 \\
(-1.01)\end{array}$ \\
\hline Log (STP unexercisable options) * PERFMEAS & $?$ & $\begin{array}{c}0.0106 \\
(0.82)\end{array}$ & $\begin{array}{l}0.0110 \\
(1.01)\end{array}$ & $\begin{array}{l}0.0136^{*} \\
(1.75)\end{array}$ \\
\hline Log (STP option grant) & + & $\begin{array}{l}0.0029^{\star *} \\
(2.44)\end{array}$ & $\begin{array}{l}0.0029^{\star \star \star} \\
(3.01)\end{array}$ & $\begin{array}{l}0.0031^{\star \star *} \\
(3.46)\end{array}$ \\
\hline Log (STP option grant) * PERFMEAS & - & $\begin{array}{l}-0.0065 \\
(-0.98)\end{array}$ & $\begin{array}{l}-0.0119^{*} \\
(-1.82)\end{array}$ & $\begin{array}{l}-0.0104^{\star \star \star} \\
(-2.89)\end{array}$ \\
\hline Accounting earnings informativeness & $?$ & $\begin{array}{l}0.0089^{\star *} \\
(2.34)\end{array}$ & $\begin{array}{l}0.0042 \\
(1.19)\end{array}$ & $\begin{array}{l}0.0028 \\
(0.97)\end{array}$ \\
\hline $\begin{array}{l}\text { Log (STP exercisable options) * Accounting } \\
\text { earnings informativeness }\end{array}$ & + & $\begin{array}{l}-0.0019^{*} \\
(-1.73)\end{array}$ & $\begin{array}{l}-0.0003 \\
(-0.29)\end{array}$ & $\begin{array}{l}0 \\
(0.09)\end{array}$ \\
\hline $\begin{array}{l}\text { Log (STP unexercisable options) * Accounting } \\
\text { earnings informativeness }\end{array}$ & $?$ & $\begin{array}{l}0.0003 \\
(0.27)\end{array}$ & $\begin{array}{l}-0.0005 \\
(-0.49)\end{array}$ & $\begin{array}{l}-0.0007 \\
(-0.87)\end{array}$ \\
\hline $\begin{array}{l}\text { Log (STP option grant) * Accounting earnings } \\
\text { informativeness }\end{array}$ & + & $\begin{array}{l}-0.0006 \\
(-0.58)\end{array}$ & $\begin{array}{l}0 \\
(-0.05)\end{array}$ & $\begin{array}{l}0.0004 \\
(0.60)\end{array}$ \\
\hline $\log ($ STP stock) & - & $\begin{array}{l}-0.0018^{\dagger} \\
(-1.57)\end{array}$ & $\begin{array}{l}-0.0021^{*} \\
(-1.83)\end{array}$ & $\begin{array}{l}-0.0011 \\
(-1.29)\end{array}$ \\
\hline Log (Firm size) & $?$ & $\begin{array}{l}-0.0040^{\dagger} \\
(-1.52)\end{array}$ & $\begin{array}{l}-0.0023 \\
(-0.96)\end{array}$ & $\begin{array}{l}-0.0032^{*} \\
(-1.79)\end{array}$ \\
\hline Leverage & $?$ & $\begin{array}{l}-0.0223^{*} \\
(-1.72)\end{array}$ & $\begin{array}{l}-0.0248^{\star *} \\
(-2.15)\end{array}$ & $\begin{array}{l}-0.0232^{\star *} \\
(-2.33)\end{array}$ \\
\hline Book-to-market & - & $\begin{array}{l}-0.0057 \\
(-0.85)\end{array}$ & $\begin{array}{l}-0.0027 \\
(-0.47)\end{array}$ & $\begin{array}{l}-0.0013 \\
(-0.29)\end{array}$ \\
\hline Net operating assets & - & $\begin{array}{l}-0.0099^{\star \star} \\
(-2.10)\end{array}$ & $\begin{array}{l}-0.0122^{\star \star \star} \\
(-2.57)\end{array}$ & $\begin{array}{l}-0.0083^{\star \star \star} \\
(-2.66)\end{array}$ \\
\hline Implicit claims & + & $\begin{array}{l}0.0190^{\star \star *} \\
(2.59)\end{array}$ & $\begin{array}{l}0.0222^{\star \star \star} \\
(3.14)\end{array}$ & $\begin{array}{l}0.0168^{* \star \star} \\
(3.15)\end{array}$ \\
\hline $\bar{N}$ & & 717 & 718 & 700 \\
\hline Adjusted $R^{2}$ & & $8.0 \%$ & $8.6 \%$ & $11.0 \%$ \\
\hline
\end{tabular}

Notes:

T-statistics (in parentheses) are based on Rogers standard errors. Coefficients on an intercept, 5 industry indicator variables and 4-year indicator variables are not reported. Variables are defined in table 4.1.

${ }^{* \star * *},{ }^{* *},{ }^{*}+{ }^{+}$denotes statistical significance at the $0.01,0.05,0.10$ and 0.15 level (two-tailed). 


\section{OPTION-BASED EQUITY INCENTIVES AND EARNINGS MANAGEMENT}

Table 4.8 Regressions of earnings management measures on the reliance on non-accounting performance measures in CEO annual bonus contracts (NFCOMP), stock option holdings, stock option compensation and other firm characteristics that affect managers' reporting choices

\begin{tabular}{|c|c|c|c|c|}
\hline \multirow[b]{2}{*}{ Independent Variable } & \multirow[b]{2}{*}{$\begin{array}{l}\text { Expected } \\
\text { sign }\end{array}$} & \multicolumn{3}{|c|}{ Coefficient Estimate } \\
\hline & & EM1 & EM2 & EM3 \\
\hline NFCOMP & $?$ & $\begin{array}{l}-0.0188 \\
(-0.19)\end{array}$ & $\begin{array}{c}0.0289 \\
(0.32)\end{array}$ & $\begin{array}{l}0.0153 \\
(0.27)\end{array}$ \\
\hline Log (STP exercisable options) & + & $\begin{array}{l}-0.0014 \\
(-1.02)\end{array}$ & $\begin{array}{l}-0.0022^{k} \\
(-1.73)\end{array}$ & $\begin{array}{l}-0.0008 \\
(-0.78)\end{array}$ \\
\hline Log (STP exercisable options) * NFCOMP & - & $\begin{array}{l}-0.0029 \\
(-0.21)\end{array}$ & $\begin{array}{l}-0.0063 \\
(-0.47)\end{array}$ & $\begin{array}{l}-0.0187^{\star *} \\
(-2.41)\end{array}$ \\
\hline Log (STP unexercisable options) & $?$ & $\begin{array}{l}-0.0014 \\
(-0.89)\end{array}$ & $\begin{array}{l}-0.0002 \\
(-0.13)\end{array}$ & $\begin{array}{l}-0.0012 \\
(-0.95)\end{array}$ \\
\hline Log (STP unexercisable options) ${ }^{*}$ NFCOMP & $?$ & $\begin{array}{c}0.0083 \\
(0.45)\end{array}$ & $\begin{array}{c}0.0123 \\
(0.75)\end{array}$ & $\begin{array}{l}0.0252^{\star *} \\
(2.03)\end{array}$ \\
\hline Log (STP option grant) & + & $\begin{array}{l}0.0028^{\star *} \\
(2.39)\end{array}$ & $\begin{array}{l}0.0028^{\star * \star} \\
(2.93)\end{array}$ & $\begin{array}{l}0.0031^{* * *} \\
(3.45)\end{array}$ \\
\hline Log (STP option grant) * NFCOMP & - & $\begin{array}{l}-0.0062 \\
(-0.60)\end{array}$ & $\begin{array}{l}-0.0175^{\dagger} \\
(-1.63)\end{array}$ & $\begin{array}{l}-0.0186^{\star \star \star} \\
(-3.14)\end{array}$ \\
\hline Accounting earnings informativeness & $?$ & $\begin{array}{l}0.0088^{\star *} \\
(2.29)\end{array}$ & $\begin{array}{l}0.0040 \\
(1.15)\end{array}$ & $\begin{array}{l}0.0028 \\
(0.96)\end{array}$ \\
\hline $\begin{array}{l}\text { Log (STP exercisable options) * Accounting } \\
\text { earnings informativeness }\end{array}$ & + & $\begin{array}{l}-0.0020^{*} \\
(-1.75)\end{array}$ & $\begin{array}{l}-0.0003 \\
(-0.32)\end{array}$ & $\begin{array}{c}0 \\
(0.05)\end{array}$ \\
\hline $\begin{array}{l}\text { Log (STP unexercisable options) }{ }^{\star} \text { Accounting } \\
\text { earnings informativeness }\end{array}$ & $?$ & $\begin{array}{l}0.0004 \\
(0.35)\end{array}$ & $\begin{array}{l}-0.0004 \\
(-0.42)\end{array}$ & $\begin{array}{l}-0.0007 \\
(-0.84)\end{array}$ \\
\hline $\begin{array}{l}\text { Log (STP option grant) * Accounting earnings } \\
\text { informativeness }\end{array}$ & + & $\begin{array}{l}-0.0006 \\
(-0.60)\end{array}$ & $\begin{array}{c}0 \\
(-0.05)\end{array}$ & $\begin{array}{l}0.0004 \\
(0.61)\end{array}$ \\
\hline Log (STP stock) & - & $\begin{array}{l}-0.0019^{\dagger} \\
(-1.60)\end{array}$ & $\begin{array}{l}-0.0022^{*} \\
(-1.84)\end{array}$ & $\begin{array}{l}-0.0011 \\
(-1.28)\end{array}$ \\
\hline Log (Firm size) & $?$ & $\begin{array}{l}-0.0039^{\dagger} \\
(-1.51)\end{array}$ & $\begin{array}{l}-0.0023 \\
(-0.97)\end{array}$ & $\begin{array}{l}-0.0033^{*} \\
(-1.84)\end{array}$ \\
\hline Leverage & $?$ & $\begin{array}{l}-0.0237^{\star} \\
(-1.80)\end{array}$ & $\begin{array}{l}-0.0258^{\star \star} \\
(-2.23)\end{array}$ & $\begin{array}{l}-0.0236^{\star *} \\
(-2.38)\end{array}$ \\
\hline Book-to-market & - & $\begin{array}{l}-0.0057 \\
(-0.86)\end{array}$ & $\begin{array}{l}-0.0028 \\
(-0.48)\end{array}$ & $\begin{array}{l}-0.0014 \\
(-0.31)\end{array}$ \\
\hline Net operating assets & - & $\begin{array}{l}-0.0094^{\star \star} \\
(-2.02)\end{array}$ & $\begin{array}{l}-0.0116^{\star \star \star} \\
(-2.56)\end{array}$ & $\begin{array}{l}-0.0081^{\star * *} \\
(-2.61)\end{array}$ \\
\hline Implicit claims & + & $\begin{array}{l}0.0194^{\star \star \star} \\
(2.61)\end{array}$ & $\begin{array}{l}0.0225^{\star \star *} \\
(3.15)\end{array}$ & $\begin{array}{l}0.0169^{\star * \star} \\
(3.16)\end{array}$ \\
\hline$N$ & & 717 & 718 & 700 \\
\hline Adjusted $R^{2}$ & & $8.0 \%$ & $8.4 \%$ & $11.0 \%$ \\
\hline $\begin{array}{l}\text { Notes: } \\
\text { T-statistics (in parentheses) are based on Rog } \\
\text { industry indicator variables and 4-year indicat } \\
\text { table } 4.1 \text {. } \\
\star \star \star \star \star \star \dagger \\
\end{array}$ & $\begin{array}{l}\text { tandard } \\
\text { ables ar } \\
0.05,0.1\end{array}$ & $\begin{array}{l}\text { ors. Coeffic } \\
\text { ot reportec }\end{array}$ & $\begin{array}{l}\text { ts on an in } \\
\text { ariables ar }\end{array}$ & $\begin{array}{l}\text { cept, } 5 \\
\text { lefined in }\end{array}$ \\
\hline
\end{tabular}




\subsection{Summary and conclusion}

In this chapter, I study the relation between CEO option-based equity incentives and earnings management conditional on the structure of the CEO's annual bonus contract. Following Hayes and Schaefer $(2000,2005), I$ argue that annual bonuses based on non-public non-accounting performance contain valuerelevant information about future performance that is not observable from publicly available accounting measures. Market participants are expected to use this value-relevant information in forming their beliefs about firm value. As a result, bonus contracts based on non-accounting performance measures act as a disciplining mechanism, which means that earnings management is likely to become less effective in influencing short-term stock prices. Therefore, I predict that managers with bonus contracts based on non-accounting performance measures will find it less worthwhile to influence market participants.

My results yield support for this hypothesis. My primary finding is that greater reliance on non-accounting performance measures in CEO annual bonus contracts discourages opportunistic earnings management aimed at influencing the exercise price of anticipated option awards. Thus, managers are less likely to make strategic accounting choices to influence the value of their option compensation if their bonus compensation is affected by performance on non-accounting measures. This shows that managers' inherent belief to be able to influence award-date-stock-prices (that equal option exercise prices) is restricted to situations in which market participants are more likely to condition their beliefs about firm value on accounting numbers.

As with any empirical study, my study has its limitations. First, it is possible that my earnings management proxies contain measurement error. Consistent with standard practice, my earnings management models aim to decompose accruals into non-discretionary and discretionary components, where earnings are expected to be managed through the manipulation of discretionary accruals. If my models do not accurately distinguish discretionary from non-discretionary accruals, it is possible that my earnings management proxies also contain a nondiscretionary component. To the extent that this non-discretionary component is correlated with the CEO's compensation structure, the possibility of a spurious relation exists. Although I address this limitation by applying two models (both the modified Jones approach and the Dechow and Dichev approach) to estimate earnings management, I cannot explicitly rule out the possibility of a spurious relation. To enrich my results, future research could further control for this by using alternative measure such as meeting or just beating analysts' forecasts.

A second limitation of my study is that I test the relation between option awards and financial reporting choice on an annual basis. Since the majority of 
option awards are granted in the four months following fiscal year-end, I decided not to distinguish between awards made near or shortly after year-end and option awards made later during the year. Conceptually, the incentives for earnings management might differ between these grant periods. While noting that my tests are more likely to work against findings of significance, a more sophisticated analysis, in which annual earnings management proxies are matched with option awards made shortly after year-end, would provide a contribution for a richer understanding of the association between financial reporting choices and observed compensation contract design.

In light of my findings, it is worth noting that although I show that specific bonus contract structures curtail option-driven earnings management, I do not claim that the choice for a specific bonus contract structure is solely driven by the aim to discourage earnings management. If firms design compensation contracts with an eye to discourage earnings management, it would likely be more cost efficient to set the exercise price of option awards as an average of the stock price over a longer period, which would make it more complicated for management to lower the exercise price by managing earnings.

Despite these limitations, my results demonstrate that bonus contracts matter. By showing that bonus contracts written on non-accounting measures affect market participants' firm value forecasts, I point to the disciplining effect of non-accounting performance information on option-driven earnings management. This illustrates the relevance of annual bonus contracts also in times where bonus pay has become small relative to option compensation. This finding is of interest to compensation committees that evaluate compensation contracts for managers, but also addresses concerns from investors and policy makers that certain compensation practices affect resource allocation decisions. Another important implication of my study is that future studies on the relation between earnings management and executive compensation should consider the interplay between existing compensation components. 


\section{Chapter 5}

\section{Summary and conclusion}

\subsection{Introduction}

This final chapter starts with a summary of the empirical findings of the three studies contained in this dissertation. Subsequently, I discuss some limitations and provide suggestions for future research. Finally, I present conclusions and implications.

\subsection{Summary}

The study in chapter 2 investigates whether and when manager-owned small businesses misreport accounting performance to influence lenders' assessments of the firm.

Since small businesses often lack a publicly available track record, their selfsupplied financial statements are of great importance in their transactions with lenders, who wish to keep track of their lending risks. However, given their desire to reduce the cost of debt capital and in the absence of third-party auditing, manager-owned small businesses have incentives to misreport earnings, even in the absence of traditional principal-agent conflicts. The practical relevance of this study thus stems from the fact that knowing what drives the reliability of small businesses' accounting information may help practitioners in assessing the trustworthiness of small businesses' self-supplied accounting information.

The hypotheses in chapter 2 derive from the ideas that small businesses minimize (loan) transaction costs and that lenders use simple earnings-based heuristics to assess the creditworthiness of small businesses. That is, the incentive to misreport earnings exists because borrowers expect that lenders offer better terms of transactions if they perceive the borrower to be profitable. My hypotheses predict that lenders' reliance on simple earnings-based heuristicsand therewith borrowers incentives to avoid reporting losses-are particularly strong if the borrower relies heavily on debt financing, has failed to develop close ties and build long-term relationships with their lenders, and is less closely 
monitored by its lenders. Strong reliance on debt financing increases the incentives for earnings management because in their assessment of highly-leveraged firms, lenders are likely to focus on cash-generating ability. The existence of close firm-lender relationships provide lenders "soft", non-accounting information about firms' activities and decreases the importance of accounting information in lenders' credit decisions. In addition, relationship lenders evaluate the profitability of their customers through multiple interactions, which reduces their reliance on single-year performance measures. Similarly, close monitoring by lenders reduces the incentives for earnings management since close monitors obtain "soft" information which substitutes for accounting information. As expected, I find that firms with a higher reliance on debt capital are more likely to avoid reporting losses. Furthermore, I find that the use of relationship financing as well as lenders' monitoring intensity are negatively associated with loss avoidance. Thus, I show that the reliability of accounting information varies significantly across small businesses. Thereby, I provide evidence that in the absence of traditional principal-agent conflicts, firms still have incentives to misreport earnings.

In chapter 3 I study the effect of CEOs price-based incentives on the reliance on alternative non-price performance measures in CEO annual bonus contracts. The central idea underlying chapter 3 is that non-price performance measures in CEO annual bonus contracts are used to overcome deficiencies of price-based performance measures. The study contributes to a better understanding of observed compensation contract designs.

To analyze two dimensions of CEOs' price-based incentives, I estimate the sensitivity of CEOs' stock and option portfolio holdings to (1) stock price (sensitivity to price or STP) and (2) stock return volatility (sensitivity to volatility or STV). While sensitivity to price and sensitivity to volatility align the incentives of executives with the interests of shareholders, they have their downsides. A high STP exposes managers to market-wide changes in equity values. A high STV encourages managerial risk taking but does not specify in what project area risks should be taken. The hypotheses in chapter 3 predict that firms link bonuses to accounting performance measures to reduce the macroeconomic risk imposed by a high STP and link bonuses to non-accounting performance measures to steer CEOs' risk taking activities in the presence of a high STV.

Consistent with my expectations, I find a positive relation between STP and the reliance on accounting performance measures. This result shows that compensation contracts include accounting performance measures to shield CEOs from macroeconomic risks. The empirical evidence also confirms my expectation that STV is positively associated with the use of non-accounting measures in annual bonus contracts. This finding indicates that firms that provide managers with incentives to invest in risky projects also use non-accounting measures to 
ensure risk taking in those areas desired by shareholders. In sum, the findings in chapter 3 show that price and non-price-based performance measures are used in a complementary way to shield CEOs from macroeconomic risk and steer risk taking activities. These results provide support for the view that alternative performance measures in CEO compensation contracts are interrelated and that future studies on executive compensation have to consider the portfolio of performance measures relevant to the CEO.

The study in chapter 4 investigates whether the effect of CEOs' stock option compensation on earnings management activities is conditional on the use of non-accounting performance measures in annual bonus contracts.

Stock option compensation aims to encourage managers to make operating and investing decisions that maximize shareholder wealth. However, regulators and investors have raised concerns that tying executive pay to stock price might also induce managers to (temporarily) influence stock price through earnings management. This concern rests on two assumptions. First, it assumes that the stock market uses current earnings to assess firm value. Second, it assumes that executives can exploit this phenomenon by manipulating earnings and thereby affecting outsiders' firm value forecasts. I argue that the use of nonaccounting performance measures in CEO annual bonus contracts enables market participants to use non-accounting performance in firm valuation decisions. Although non-accounting performance measures are of use to investors, because of their capacity to be leading indicators of future financial performance, they are often unobservable. However, the variation in current compensation that is not explained by current accounting measures signals to investors what the CEO's performance on the non-accounting measures has been. Because investors can use this signal to assess the reliability of accounting disclosures, the use of non-accounting measures in bonus contracts disciplines CEOs' earnings management activities.

Non-accounting performance measures' ability to discipline earnings management increases with the weight attached to these measures because of two reasons. First, the importance of non-accounting performance measures for valuation is likely to be positively associated with their usefulness in bonus decisions. Second, the informativeness of the signal about non-accounting performance increases as the weight attached to non-accounting performance measures increases. This implies that earnings management is less likely to influence short-term stock prices when non-accounting measures receive more weight in bonus contracts. In line with this reasoning, I test whether greater reliance on non-accounting performance measures in CEO annual bonus contracts decreases the impact of option-based equity incentives on the incidence of earnings management. 
In my analyses I identify three option categories: newly granted options, previously granted unexercisable options, and previously granted exercisable options. Because CEOs' earnings management activities most likely have a temporary effect on stock prices, such activities most likely take place around the option grant date or option exercise date. Consequently, the predicted moderating effect of the use of non-accounting performance measures on the link between STP and earnings management must be stronger for newly granted and exercisable options than for unexercisable options.

Consistent with my expectations, I find that the importance of nonaccounting performance measures in CEO annual bonus contracts reduces the effect of newly granted options on earnings management. In contrast, I find no support for the moderating effect of non-accounting performance measures on the association between earnings management and the incentive-intensity of the CEO's exercisable option holdings. This result can be explained by the idea that the value of exercisable options is positively influenced by stock price increases, which are less easily achieved than stock price decreases. In addition, since exercise periods for exercisable options cover a longer time span, which might already encompass a stock price high, earnings management for exercisable options is not always necessary. My results are not driven by the possibility that firms that place more weight on non-accounting performance measures in bonus contracts report accounting numbers that are less informative about firm value. Overall, these results show that the use of non-accounting performance measures in CEO annual bonus contracts mitigates option compensation-induced earnings management.

\subsection{Limitations and suggestions for future research}

As with any empirical study, my study has its limitations. An implicit assumption of my analyses in chapter 2 is that the earnings number drawn from the NSSBF database equals the amount presented to potential and existing lenders. A limitation of my study remains that I cannot test this assumption explicitly. In addition, since the NSSBF database only contains financial statement data on an annual basis, the focus of my investigation is on loss avoidance. Once more data becomes available on manager-owned small businesses, future research may analyze these firms' accounting decisions in more detail.

To examine the interrelation between price and non-price-based performance measures in chapter 3,1 use three proxies for the incentive-intensity of non-price performance measures in CEO annual bonus contracts. The non-price performance measures I study mainly reflect the aggregate importance of accounting and non-accounting performance measures. It may be, however, that some non-price performance measures are more effective risk management 
devices than others. Future research could assess the robustness of my results by examining more specific proxies for the use of non-price measures in CEO annual bonus contracts.

A second limitation of the study in chapter 3 concerns the possibility of correlated omitted variables. My model yields inconsistent parameters to the extent that some of the determinants of the price-based measures I use also affect my non-price-based proxies. Nevertheless, given the prior literature I used to the select my control variables to deal with this risk, I am not aware of any other variable that is correlated with the variables measuring price and non-price performance measures.

A limitation in the analysis in chapter 4 follows from the earnings management proxies used. Each of my earnings management measures is based on estimates of unobservable discretionary accruals. Consistent with prior literature these discretionary accruals are estimated using traditional earnings management models (the modified Jones approach and the Dechow and Dichev approach). It is possible that these models are misspecified and imperfectly separate discretionary from non-discretionary accruals. Consequently, it is possible that my earnings management proxies contain a non-discretionary component that could cause a spurious relation if it is correlated with compensation structure. I use two different earnings management models to reduce the influence of this measurement error. Future research could further assess the robustness of the results by using earnings management measures that are not based on the decomposition of accruals (e.g., meeting or just beating analysts' forecasts).

A second limitation of the analysis in chapter 4 is that the option awards that $I$ analyze can be granted any time during the year, whereas the earnings management proxies I use are measured annually. Noting that my tests are more likely to work against findings of significance, future research could refine my results by matching the earnings management proxies with option awards made shortly after year-end.

\subsection{Conclusion and implications}

This dissertation examines the use and effects of price and non-price-based performance measures in debt and compensation contracts.

The study in chapter 2 focuses on debt contracting and provides insights into the financial reporting consequences of small firms' loan and lending relationship characteristics. Since small businesses often lack a publicly available track record, their self-supplied accounting statements provide lenders with the primary source of information. In chapter 2, I show that small businesses avoid reporting losses if their lenders are likely to use accounting information in their credit granting decisions and monitoring activities. Hereby, reporting choices 
potentially distort the efficient allocation of capital in the economy. Additionally, this phenomenon increases the risk of creditors' loan portfolios and, consequently, may increase the overall cost of debt for small businesses. This would make it even more difficult for small businesses to raise capital.

Recent developments in the credit granting and monitoring process show that credit decisions are increasingly based on credit scoring models and computerized decision rules. In addition, credit scoring models have become an essential component of banks' risk management systems. These developments further emphasize the importance of small businesses' accounting reports and thereby increase the importance of my findings. The study in chapter 2 addresses concerns from investors and policy makers about the trustworthiness of small businesses' self-supplied accounting information. It shows that the mechanical use of accounting information by banks (e.g., separate loss-making small businesses from profitable small businesses) may not only reduce the efficiency of capital allocation but also impair the effectiveness of banks' risk management systems.

The analyses in chapter 3 and 4 focus on compensation contracts. In chapter 3,1 examine how price and non-price-based incentives combine to motivate managers to take the right actions. Traditionally, most executive pay packages contain an annual bonus tied to accounting performance. Accounting information is readily available and provides information about whether and how managers' actions affect near-term performance. In addition, many pay packages currently include forward-looking incentive mechanisms to motivate managers to expand effort on activities with positive payoffs beyond the immediate future. Two types of forward-looking incentive mechanisms are bonuses tied to non-accounting performance and stock price-based incentives, such as stock options. In chapter 3,1 consider the costs and benefits of each of these incentive mechanisms and argue that some mechanisms are used to overcome dysfunctional behavior caused by other mechanisms. In particular, I show that firms use accounting measures to shield CEOs from market-wide price shocks when they hold options and shares in their firms. In addition, firms use non-accounting performance measures to steer CEOs' risk taking activities in the direction desired by shareholders. My findings indicate that the interplay of performance measures establishes the optimal level of portfolio incentives. An important implication of my study is that in order to understand what motivates CEOs, outsiders have to consider not only the CEOs' stock and option holdings but also the composition of their bonuses, irrespective of how small the latter salary component may be relative to the former component.

In chapter 4, I study the reporting consequences of specific compensation structures. I find that non-accounting performance measures function as a disciplining measure to mitigate option-driven earnings management. The 
central idea of chapter 4 is that investors assess firm value using reported accounting performance as well as non-accounting performance, which they infer from the variation in current compensation that is not explained by current accounting performance. Because investors receive a costly and credible signal about the reliability and permanence of reported accounting performance, earnings management to influence the firm's stock price becomes less effective and therefore less practiced. My findings with respect to option grants are consistent with this idea. Hereby, the analysis in chapter 4 also illustrates the relevance of annual bonus contracts in times where bonus pay has become small relative to option compensation. It is important to note, however, that the final composition of a compensation contract remains a firm-specific process. While I argue that accounting measures reduce risk exposure in chapter 3 , it is obvious from my analyses in chapter 4 that accounting measures might allow or even induce earnings management as well. Consequently, each compensation committee should carefully consider the net benefits of performance measure adoption in its own firm-specific operating environment. The findings in chapter 4, nevertheless, emphasize that a relatively inexpensive adjustment to compensation contracts (i.e., tie bonuses at least partly to undisclosed non-accounting performance) can help to mitigate one of the primary drawbacks of option compensation, option-driven earnings management.

The studies in chapters 3 and 4 both illustrate how detailed disclosures about CEOs' bonus composition can be of use to outsiders, such as investors. The findings therefore emphasize how important it is that compensation committees or supervisory boards report on how they determine the bonuses that they award to their CEOs-not only how much they pay. An important step towards disclosure of this information in the Netherlands is provided by the Dutch corporate governance code ("code Tabaksblat"). This code, which applies on a "comply or explain" basis to firms listed in the Netherlands, prescribes firms to provide an explanation of the performance criteria that determine variable remuneration components. In addition, firms are supposed to explain the choice for these methods. Furthermore, these firms are expected to provide a summary of the methods that will be applied to determine whether these performance criteria have been fulfilled. The studies in chapters 3 and 4 of this dissertation provide evidence to the relevance of this information. 
Appendices 


\section{Appendix A.}

\section{Estimating sensitivities of individual stock options}

Calculating Black-Scholes value and sensitivities of individual stock options Estimates of a stock option's value or sensitivity to stock price or stock return volatility are calculated based on the Black-Scholes (1973) formula for valuing European call options, as modified to account for dividend payouts by Merton (1973).

Option value $=\left(S e^{-d T} N[Z]-X e^{-r T} N\left[Z-\sigma T^{(1 / 2)}\right]\right)$

where:

$Z=\left(\ln [S / X]+T\left[r-d+\sigma^{2} / 2\right]\right) / \sigma T^{(1 / 2)}$

$\mathrm{N}=$ cumulative probability function for the normal distribution

$S=$ price of the underlying stock

$X=$ exercise price of the option

$\sigma=$ expected stock return volatility over the life of the option

$r=$ natural logarithm of risk-free interest rate

$\mathrm{T}=$ time to maturity of the option in years

$d=$ natural logarithm of expected dividend yield over the life of the option

The sensitivity with respect to a $1 \%$ change in stock price is defined as:

$(\delta[\text { option value }] / \delta[\text { price }])^{*}($ price $/ 100)=e^{-d T} N(Z)^{*}($ price $/ 100)$

The sensitivity with respect to a 0.01 change in stock return volatility is defined as:

$(\delta[$ option value $] / \delta[$ stock volatility $]) *(0.01)=e^{-d T} N^{\prime}(Z) S T^{(1 / 2)} *(0.01)$

where $N^{\prime}=$ normal density function 


\section{Apprendizes.}

\section{Estimating earnings management proxies}

In this appendix, I describe the calculation of my three earnings management proxies. Following the modified Jones model, I first regress total accruals on changes in revenues and PPE. The accrual estimation is conducted for each two-digit SIC industry group containing at least 20 firms in each year for the years 1998-2002. ${ }^{37}$

$\frac{T A_{j, t}}{\text { Asset }_{j, t-1}}=\kappa_{1, t} \frac{1}{\text { Asset }_{j, t-1}}+\kappa_{2, t} \frac{\Delta R E V_{j, t}}{\text { Asset }_{j, t-1}}+\kappa_{3, t} \frac{P P E_{j, t}}{\text { Asset }_{j, t-1}}+\varepsilon_{j, t}$

where:

$T A_{j, t}=$ firm $j$ 's total accruals in year $t$, calculated as

$T A_{j, t}=\left(\triangle C A_{j, t}-\triangle C L_{j, t}-\triangle C A S H_{j, t}+\triangle S T D E B T_{j, t}-D E P N_{j, t}\right)$

$\Delta C A_{j, t}=$ firm $j$ 's change in current assets in year $t$,

$\triangle C L_{j, t}=$ firm $j$ 's change in current liabilities in year $t$,

$\triangle C A S H_{j, t}=$ firm $j$ 's change in cash in year $t$,

$\triangle S T D E B T_{j, t}=$ firm $j$ 's change in short-term debt in year $t$,

$D E P N_{j, t}=$ firm j's depreciation and amortization expense in year $t$,

$\triangle R E V_{j, t}=$ firm $j$ 's change in revenues in year $t$,

$P P E_{j, t}=$ firm j's gross value of property, plant, and equipment in year $t$, and

Asset $_{j, t-1}=$ firm $j$ 's total assets in year $t-1$.

I use the industry- and year-specific parameter estimates from equation (1) to estimate firm-specific normal accruals $\left(N A_{j, t}\right)$ as a percent of lagged total assets.

$N A_{j, t}=\hat{\kappa}_{1, t} \frac{1}{\text { Asset }_{j, t-1}}+\hat{\kappa}_{2, t} \frac{\left(\Delta R E V_{j, t}-\Delta A R_{j, t}\right)}{\text { Asset }_{j, t-1}}+\hat{\kappa}_{3, t} \frac{P P E_{j, t}}{\text { Asset }_{j, t-1}}$

where:

$\Delta A R_{j, t}=$ firm $j$ 's change in accounts receivable in year $t$,

${ }^{37}$ To mitigate the influence of outliers, each continuous variable used in the calculation of my three earnings management proxies is winsorized at the $1 \%$ level of the distribution (e.g., Cheng and Warfield, 2005). 
From this, I calculate abnormal accruals $\left(A A_{j, t}\right)$ for firm $j$ in year $t$.

$$
A A_{j, t}=\frac{T A_{j, t}}{A s s e t}-N A_{j, t}
$$

My first proxy for the level of earnings management $\left(E M 1_{j, t}\right)$ is the absolute value of the abnormal accruals $\left(A A_{j, t}\right)$, calculated as shown above. Larger values of $E M 1_{j, t}$ indicate a greater level of earnings management.

Following Aboody et al. (2005) I also apply the modified Jones model to estimate abnormal current accruals.

$$
\frac{T C A_{j, t}}{\text { Asset }_{j, t-1}}=\gamma_{1, t} \frac{1}{\text { Asset }_{j, t-1}}+\gamma_{2, t} \frac{\Delta R E V_{j, t}}{\text { Asset }_{j, t-1}}+\mu_{j, t}
$$

where:

$T C A_{j, t}=$ firm $j$ s total current accruals in year $t$, calculated as

$$
T C A_{j, t}=\left(\Delta C A_{j, t}-\Delta C L_{j, t}-\Delta C A S H_{j, t}+\Delta S T D E B T_{j, t}\right)
$$

Similar to total accruals, I use the industry- and year-specific parameter estimates from equation (2) to estimate firm-specific normal current accruals $\left(N C A_{j, t}\right)$ as a percent of lagged total assets.

$$
N C A_{j, t}=\hat{\gamma}_{1, t} \frac{1}{A s s e t}+\hat{\gamma}_{j, t} \frac{\left(\Delta R E V_{j, t}-\Delta A R_{j, t}\right)}{\text { Asset }_{j, t-1}}
$$

This enables me to calculate the abnormal current accrual $\left(A C A_{j, t}\right)$ for firm $j$ in year $t$.

$$
A C A_{j, t}=\frac{T C A_{j, t}}{\text { Asset }_{j, t-1}}-N C A_{j, t}
$$

The absolute value of the resulting measure of abnormal current accruals ( $A$ $\left.C A_{j, t}\right)$ is my second proxy for the level of earnings management $\left(E M 2_{j, t}\right)$. Similar to $E M 1_{j, t}$ larger values of $E M 2_{j, t}$ reflect greater levels of earnings management. My third and final earnings management measure proceeds from the approach by Dechow and Dichev (2002). The Dechow and Dichev (2002) model is based 
on the extent to which working capital accruals map into cash flow realizations. Similar to the estimation of the modified Jones model, the Dechow and Dichev (2002) estimation is conducted for each two-digit SIC industry group containing at least 20 firms in each year for the years 1998-2002.

$\frac{T C A_{j, t}}{\text { Aveasset }_{j, t}}=\theta_{0, t}+\theta_{1, t} \frac{C F O_{j, t-1}}{\text { Aveasset }_{j, t}}+\theta_{2, t} \frac{C_{\text {Aveasset }} \text { A }_{j, t}}{\text { Aver }_{j, t}}+\theta_{3, t} \frac{C F O_{j, t+1}}{\text { Aveasset }_{j, t}}+v_{j, t}$

where:

$C F O_{j, t-1}=$ firm j's operating cash flow in year $t-1$,

$\mathrm{CFO}_{j, t}=$ firm $j$ 's operating cash flow in year $t$,

$C F O_{j, t+1}=$ firm $j$ 's operating cash flow in year $t+1$,

Aveasset $t_{j, t}=$ firm $j$ 's average total assets over years $t$ and $t-1$.

My third proxy for the level of earnings management $\left(E M 3_{j, t}\right)$ is the absolute value of firm $j$ 's annual residuals $\left(\left|\hat{v}_{j, t}\right|\right)$ from equation (3). Consistent with the construction of the other measures, larger absolute residuals indicate greater levels of earnings management or lower earnings quality. 


\section{References}

Aboody, D., J.S. Hughes and J. Liu, 2005. Earnings quality, insider trading, and cost of capital. Journal of Accounting Research 5, 651-673.

Altman, E., 1968. Financial ratios, discriminant analysis and the prediction of corporate bankruptcy. The Journal of Finance $23,589-609$.

Ang, J., R. Cole and J. Wuh Lin, 2000. Agency costs and ownership structure. The Journal of Finance $55,81-106$.

Baker, T., D. Collins and A. Reitenga, 2003. Stock option compensation and earnings management incentives. Journal of Accounting, Auditing \& Finance 18, 557-582.

Barton, J. and P.J. Simko, 2002. The balance sheet as an earnings management constraint. The Accounting Review 77 (Supplement), 1-27.

Beatty, A. and H.G. Harris, 1999. The effects of taxes, agency costs and information asymmetry on earnings management: A comparison of public and private firms. Review of Accounting Studies 4, 299-326.

Beaulieu, P.R., 1994. Commercial lenders' use of accounting information in interaction with source credibility. Contemporary Accounting Research 10, 557-585.

Berger, A.N. and G.F. Udell, 1995. Small firms, commercial lines of credit, and coliateral. Journal of Business 68, 351-382.

Berger, A.N. and G.F. Udell, 1998. The economics of small business finance: The roles of private equity and debt markets in the financial growth cycle. Journal of Banking and Finance 22, 613-673.

Bitler, M., A.M. Robb and J.D. Wolken, 2001. Financial services used by small businesses: Evidence from the 1998 Survey of Small Business Finances. Federal Reserve Bulletin 87, 183-205.

Black, E.L., 1998. Life-cycle impacts on the incremental value-relevance of earnings and cash flow measures. Journal Financial Statement Analysis 4, 40-56.

Black, F. and M. Scholes, 1973. The pricing of options and corporate liabilities. Journal of Political Economy 81, 637-654.

Boot, A.W.A, 2000. Relationship banking: what do I know? Journal of Financial Intermediation 9, 7-25.

Boot, A.W.A. and A.V. Thakor, 1994. Moral hazard and secured lending in an infinitely repeated credit market game. International Economic Review 35, 899-920.

Bowen, R., L. DuCharme and D. Shores, 1995. Stakeholders' implicit claims and accounting method choice. Journal of Accounting and Economics 20, 255-295. 


\section{REFERENCES}

Bulow, J.l. and J.B. Shoven, 1978. The bankruptcy decision. Bell Journal of Economics 9, 437-456.

Burgstahier, D. and I. Dichev, 1997. Earnings management to avoid earnings decreases and losses. Journal of Accounting and Economics 24, 99-126.

Burgstahler, D.C. and M.J. Eames, 2003. Earnings management to avoid losses and earnings decreases: Are analysts fooled? Contemporary Accounting Research 20, 253-294.

Bushman, R.M., R.J. Indjejikian and A. Smith, 1996. CEO compensation: The role of individual performance evaluation. Journal of Accounting and Economics 21, 161-193.

Carletti, E., 2004. The structure of bank relationships, endogenous monitoring, and loan rates. Journal of Financial Intermediation 13, 58-86.

Cheng, Q. and T. Warfield, 2005. Equity incentives and earnings management. The Accounting Review 80, 441-477.

Cole, R.A., 1998. The importance of relationships to the availability of credit. Journal of Banking and Finance 22, 959-977.

Cole, R.A., L.G. Goldberg and L.J. White, 2004. Cookie cutter vs character: The micro structure of small business lending by large and small banks. Journal of Financial and Quantitative Analysis 39, 227-251.

Cole, R.A. and J.D. Wolken, 1995. Financial services used by small businesses: Evidence from the 1993 National Survey of Small Business Finances. Federal Reserve Bulletin 81, 630-667.

Collins, D. and P. Hribar, 2002. Errors in estimating accruals, implications for empirical research. Journal of Accounting Research 40, 105-134.

Conlisk, J., 1996. Why bounded rationality? Journal of Economic Literature, 669-700.

Core, J.E. and W.R. Guay, 1999. The use of equity grants to manage optimal equity incentive levels. Journal of Accounting and Economics 28, 151-184.

Core, J.E. and D.F. Larcker, 2002. Performance consequences of mandatory increases in executive stock ownership. Journal of Financial Economics 64, 317-340.

Core, J.E., R.W. Holthausen and D.F. Larcker, 1999. Corporate governance, chief executive officer compensation, and firm performance. Journal of Financial Economics 51, 371-406.

Danos, P., D.L. Holt and E.A. imhoff, 1989. The use of accounting information in bank lending decisions. Accounting, Organizations and Society 14, 235-246.

Dechow, P.M. and I. Dichev, 2002. The quality of accruals and earnings: The role of accrual estimation errors. The Accounting Review 77, 35-59.

Dechow, P.M., R.G. Sioan and A.P. Sweeney, 1995. Detecting earnings management. The Accounting Review 70, 193-225.

Degeorge, F., J. Patel and R. Zeckhauser, 1999. Earnings management to exceed thresholds. Journal of Business $72,1-33$. 
Degryse, H. and P. Van Cayseele, 2000. Relationship lending within a bank-based system: evidence from European small business data. Journal of Financial Intermediation 9, 90-109.

Demsetz, H. and K. Lehn, 1985. The structure of corporate ownership: causes and consequences. Journal of Political Economy 93, 1155-1177.

Diamond, D., 1984. Financial intermediation and delegated monitoring. Review of Economic Studies $51,393-414$.

Diamond, D., 1991. Monitoring and reputation: The choice between bank loans and directly placed debt. Journal of Political Economy 99, 688-721.

Elsas, R., 2005. Empirical determinants of relationship lending. Journal of Financial Intermediation 14 , 32-57.

Fama, E., 1985. What's different about banks? Journal of Monetary Economics 15, 29-39.

Feltham, G.A. and J. Xie, 1994. Performance measures congruity and diversity in multi-task principal/agent relations. The Accounting Review 69, 429-453.

Frankel, F., M.F. Johnson and K.K. Nelson, 2002. The relation between auditors' fees for nonaudit services and earnings management. The Accounting Review 77, 71-105.

Gibbons, R. and K.J. Murphy, 1990. Relative performance evaluation for chief executive officers. Industrial and Labor Relations Review 43, 30-51.

Gorton, G. and J. Kahn, 2000. The design of bank loan contracts. Review of Financial Studies 13, 331-364.

Greene, W.H, 2000. Econometric Analysis. Fourth edition, Prentice-Hall, NJ.

Guay, W.R., 1999. The sensitivity of CEO wealth to equity risk: an analysis of the magnitude and determinants. Journal of Financial Economics, 43-71.

Hall, B.J., 2003. Six challenges in designing equity-based pay. Working Paper, National Bureau of Economic Research, 1-27.

Hanlon, M., S. Rajgopal and T. Shevlin, 2003. Are executive stock options associated with future earnings? Journal of Accounting and Economics 36, 3-43.

Hayes, R. and S. Schaefer, 2005. Bonuses and non-public information in publicly traded firms. Review of Accounting Studies 10, 431-464.

Hayes, R. and S. Schaefer, 2000. Implicit contracts and the explanatory power of top executive compensation for future performance. The RAND Journal of Economics 31, 273-293.

Heckman, J., 1979. Sample selection bias as a specification error. Econometrica 47, 153-161.

Höppe, F., 2008. Incentives and the signaling effects of annual bonus schemes: evidence from firm innovation. Working Paper, Maastricht University.

Höppe, F. and F. Moers, 2007. Bonus contracts, private information and CEO turnover. Working Paper, Maastricht University. 
Itiner, C.D., R.A. Lambert and D.F. Larcker, 2003. The structure and performance consequences of equity grants to employees of new economy firms. Journal of Accounting and Economics $34,89-127$.

Ittner, C.D. and D.F. Larcker, 1998. Are non-financial measures leading indicators of financial performance? An analysis of customer satisfaction. Journal of Accounting Research 36 (Sup. plement), 1-46.

Ittner, C.D., D.F. Larcker and M.V. Rajan, 1997. The choice of performance measures in annual bonus contracts. The Accounting Review 72, 231-255.

James, C., 1987. Some evidence on the uniqueness of bank loans. Journal of Financial Economics $19,217-235$

Kahneman, D. and A. Tversky, 1979. Prospect theory: An analysis of decision under risk. Econometrica $47,263-291$.

Knopf, J.D., J. Nam and J.H. Thornton JR, 2002. The Volatility and Price Sensitivities of Managerial Stock Option Portfolios and Corporate Hedging. The Journal of Finance 57, 801-813.

Lambert, R.A., 2001. Contracting theory and accounting. Journal of Accounting and Economics, 3-87.

Lambert, R.A., D.F. Larcker and R.E. Verrecchia, 1991. Portfolio considerations in valuing executive compensation. Journal of Accounting Research 29, 129-149.

McNichols, M.F., 2000. Research design issues in earnings management studies. Journal of Accounting and Public Policy 19, 313-345.

Merton, R., 1973. Theory of rational option pricing. Bell Journal of Economics and Management Science 4, 141-183.

Mikhail, M.B., 1999. Coordination of earnings, regulatory capital and taxes in private and public companies. Working Paper, Massachusetts Institute of Technology, 1-53.

Murphy, K.J., 1999. Executive compensation, in Orley Ashenfelter and David Card (eds.), Handbook of Labor Economics, North Holland.

Myers, S.C., 1984. The capital structure puzzle. The Journal of Finance 39, 575-592.

National Academy of Engineering, 1992. Time horizons and technology investments (National Academy Press, Washington, DC).

NRC, February 19,2008. Top Philips haalt doelen niet en krijgt lagere bonus.

Paul, J.M., 1992. On the efficiency of stock-based compensation. Review of Financial Studies 5, 471 502.

Petersen, M.A. and R.G. Rajan, 1994. The benefits of lending relationships: Evidence from small businesses. The Journal of Finance 49, 3-37.

Petersen, M.A. and R.G. Rajan 1997. Trade credit: Theories and evidence. Review of Financial Studies 10, 661-691. 
Petersen, M.A. and R.G. Rajan, 2002. Does distance still matter? The information revolution in small business lending. The Journal of Finance 57, 2533-2570.

Petersen, M., 2005. Estimating standard errors in finance panel data sets: comparing approaches. Working Paper, Northwestern University.

Rajgopal, S., T. Shevlin and V. Zamora, 2006. CEOs' outside employment opportunities and the lack of relative performance evaluation in compensation contracts. The Journal of Finance 61 1813-1844.

Richardson, S., I. Tuna and M. Wu, 2002. Predicting earnings management: the case of earnings restatements. Working Paper.

Rogers, W., 1993. Regression standard errors in clustered samples. Stata Technical Bulletin 13, 1923.

Said, A.A., H.R. HassabElnaby and B. Wier, 2003. An empirical investigation of the performance consequences of nonfinancial measures. Journal of Management Accounting Research 15, 193-223.

Shleifer, A. and R.W. Vishny, 1997. A survey of corporate governance. The Journal of Finance 52, 737-784.

Skinner, D.J. and R.G. Sloan, 2002. Earnings surprises, growth expectations, and stock returns or don't let an earnings torpedo sink my portfolio. Roview of Accounting Studies 7, 289-312.

Sloan, R.G., 1993. Accounting earnings and top executive compensation. Journal of Accounting and Economics $16,55-100$.

Stiglitz, J.E. and A. Weiss, 1983. Incentive effects of terminations: applications to the credit and labor markets. American Economic Review 73, 912-927.

Wang, D., 2006. Founding family ownership and earnings quality. Journal of Accounting Research 44, $619-656$.

Warfield, T.D., J.J. Wild and K.L. Wild, 1995. Managerial ownership, accounting choices, and informativeness of earnings. Journal of Accounting and Economics 20, 61-91. 


\section{Summary in Dutch (Nederlandse samenvatting)}

Dit proefschrift bestudeert het gebruik van aandelenprijs gerelateerde en nietaandelenprijs gerelateerde prestatiemaatstaven in de beoordeling van kredietaanvragen en in de beloningstructuur van Chief Executive Officers (CEOs). Prestatiemaatstaven worden gebruikt om een onderneming en/of bijbehorend management te evalueren. Een belangrijke groep niet-aandelenprijs gerelateerde prestatiemaatstaven zijn accounting gerelateerde maatstaven. Veelvoorkomende accounting gerelateerde maatstaven zijn omzet, winst en winstgroei. Accounting gerelateerde maatstaven worden in de meeste organisaties gebruikt en hebben in vergelijking met andere prestatiemaatstaven het voordeel dat ze relatief eenvoudig en goedkoop te genereren zijn. Bovendien is accounting informatie begrijpelijk en controleerbaar. Een nadeel van het gebruik van accounting maatstaven is, dat deze maatstaven verslaggevingskeuzes kunnen beïnvloeden. In hoofdstuk 2 van dit proefschrift bestudeer ik dit probleem. Ik onderzoek in hoeverre het gebruik van accounting gerelateerde maatstaven in het verwerkingsproces van een mogelijke kredietaanvraag de verslaggevingskeuzes van ondernemingen beïnvloedt, met als uiteindelijke doel de financieringskosten te verlagen.

Het idee voor deze studie komt voort uit de veronderstelling dat de contractvoorwaarden en daarmee transactiekosten voor een krediet, beïnvloed worden door de winstgevendheid van de kredietnemer. Een winstgevende onderneming wordt verondersteld gunstigere krediet-contractvoorwaarden te kunnen afdwingen dan een verliesgevende onderneming. Hierdoor heeft de kredietnemer een prikkel om de door de kredietverstrekker veronderstelde winstgevendheid te beïnvloeden. In hoofdstuk 2 analyseer ik een drietal situaties waarin ik verwacht dat een kredietverstrekker een winstgevendheidscriterium gebruikt om de kredietwaardigheid van de kredietnemer te beoordelen. Ik beperk mijn analyse tot ondernemingen waarbij de bestuurder tevens de eigenaar van de onderneming is (eigenaar = bestuurder) om traditionele principaal-agent problemen (eigenaar $\neq$ bestuurder) uit te sluiten. In de eerste plaats verwacht ik het gebruik van een winstgevendheidscriterium voor ondernemingen die voor een groot deel met vreemd vermogen gefinancierd zijn. Kredietverstrekkers zullen in dit geval letten op het vermogen van deze ondernemingen om cash te genereren, en daarbij de vuistregel hanteren dat winstgevende ondernemingen een grotere waarschijnlijkheid hiertoe hebben dan verliesgevende ondernemingen. Ten tweede verwacht ik dat een goed onderling contact tussen kredietverstrekker en kredietne- 
mer ertoe leidt dat de verwerking van een kredietaanvraag minder snel alleen op winstgevendheid gebaseerd zal zijn. Tenslotte, verwacht ik een toename van het gebruik van winstgevendheidscriteria in gevallen waar ondernemingen meerdere kredietcontracten bij verschillende kredietverstrekkers hebben. In dit geval wordt het voor iedere kredietverstrekker te kostbaar om een gedetailleerd beoordelingsproces door te voeren.

De resultaten van de studie zijn in lijn met mijn verwachtingen en laten zien dat de verslaggevingskeuzes van ondernemingen beïnvloed worden door het geanticipeerde gebruik van winstgevendheidscriteria door kredietverstrekkers. Ik toon hiermee aan dat kredietrelaties van invloed zijn op de verslaggevingskeuzes van ondernemingen die niet door principaal-agent problemen beïnvloed worden. Dit resultaat is van belang voor alle partijen die beslissingen baseren op de door deze ondernemingen zelf verstrekte financiële informatie.

Naast het feit dat het gebruik van accounting gerelateerde maatstaven tot winststuring kan leiden, wordt de geschiktheid van accounting gerelateerde prestatiemaatstaven negatief beïnvloed door het feit dat deze maatstaven een korte termijn oriëntatie tot gevolg hebben. De lange termijn effecten van investeringsbeslissingen en onderzoeksactiviteiten worden niet optimaal gereflecteerd en daardoor niet optimaal gestimuleerd door accounting maatstaven. Om een korte termijn oriëntatie te vermijden en het nemen van risico's te stimuleren wordt in veel organisaties gebruik gemaakt van toekomstgeoriënteerde, aanvullende prestatiemaatstaven. De bedoeling hiervan is, managers te motiveren de doelstellingen van de organisatie na te streven. De meest gebruikte toekomstgeoriënteerde prestatiemaatstaven zijn aandelenprijs gerelateerde maatstaven. In hoofdstuk 3 bestudeer ik het samenspel van aandelenprijs gerelateerde maatstaven en niet-aandelenprijs gerelateerde maatstaven om elkaars tekortkomingen te compenseren. Ik gebruik twee maatstaven voor het gebruik van aandelenprijs gerelateerde prestatiemaatstaven: als eerste de mate waarin de waarde van de aan de CEO toegekende opties en aandelen beïnvloed wordt door veranderingen in de aandelenprijs, STP (Sensitivity to Stock Price) en als tweede de mate waarin de waarde van de aan de CEO toegekende opties beïnvloed wordt door schommelingen in aandelenrendementen, STV (Sensitivity to Stock Return Volatility). Beide maatstaven worden gebruikt om het gedrag van bestuurders in overeenstemming te brengen met de doelstellingen van de onderneming. Echter, beide maatstaven hebben ook tekortkomingen. Een hoge STP stelt bestuurders bloot aan marktfluctuaties van aandelenkoersen. Een hoge STV stimuleert risicovol gedrag, maar geeft niet aan in welke richting risico's genomen moeten worden. In het betreffende hoofdstuk bestudeer ik hoe ondernemingen met deze tekortkomingen omgaan. Ik verwacht dat zij hier nietaandelenprijs gerelateerde prestatiemaatstaven voor gebruiken. De eerste hypothese stelt dat ondernemingen accounting informatie in bonussen gebruiken 
om het risico van macroeconomische koersfluctuaties te beperken. Het voordeel van accounting maatstaven ten opzichte van andere maatstaven die ook beschermen tegen macroeconomische risico's, komt voort uit de goede beschikbaarheid en lage kosten van accounting informatie. Bovendien is accounting informatie begrijpelijk en controleerbaar. Tenslotte zorgt een combinatie van accounting- en aandelenprijs gerelateerde prestatiemaatstaven voor een focus op de korte en lange termijn. De tweede hypothese stelt dat ondernemingen niet-accounting gerelateerde maatstaven gebruiken om risicovol gedrag een bepaalde richting in te sturen. Een voorbeeld hiervoor is het stimuleren van innovatief gedrag. Niet-accounting gerelateerde prestatiemaatstaven die op nieuwe productontwikkeling gericht zijn, zullen beter in staat zijn innovatief gedrag te stimuleren dan accounting gerelateerde prestatiemaatstaven.

De resultaten in hoofdtuk 3 bevestigen deze verwachtingen en geven aan dat aandelenprijs gerelateerde en niet-aandelenprijs gerelateerde prestatiemaatstaven elkaar aanvullen om macroeconomische risico's te beperken en risicovol gedrag een bepaalde richting in te sturen. Deze resultaten bieden inzicht in beloningsystemen en tonen aan dat toekomstig onderzoek rekening moet houden met het samenspel van prestatiemaatstaven in beloningstructuren.

In hoofdstuk 4 bestudeer ik een belangrijk gevolg van het gebruik van een combinatie van aandelenprijs gerelateerde en niet-aandelenprijs gerelateerde prestatiemaatstaven. Net als bij het gebruik van accounting gerelateerde maatstaven, kan het toekennen van aandelenopties aan de leden van de raad van bestuur de verslaggevingskeuzes van ondernemingen beïnvloeden. Deze zorg berust op twee aannames. In de eerste plaats wordt verondersteld dat winstcijfers een invloed hebben op aandelenprijzen. Ten tweede wordt aangenomen dat bestuurders gebruik kunnen maken van dit fenomeen door winsten te sturen en daarmee de marktwaarde van de onderneming te beïnvloeden met als doel de waarde van hun opties te vergroten. Het effect van winststuring op de aandelenprijs wordt beïnvloed door andere informatie waarmee afgeleid kan worden of de winstverandering een éénmalig danwel een langdurig karakter heeft. Ik argumenteer dat het gebruik van niet-accounting gerelateerde prestatiemaatstaven in de bonusuitkering van de leden van de raad van bestuur dit onderscheid mogelijk maakt, omdat deze maatstaven erdoor gekenmerkt worden toekomstige financiële prestaties weer te geven. Zo kan bijvoorbeeld een situatie waarin een onderneming een onverwacht hoge winst rapporteert, terwijl de leden van de raad van bestuur geen corresponderende bonusuitkering krijgen, erop wijzen dat de gebruikte niet-accounting gerelateerde prestatiemaatstaven een hogere bonus niet rechtvaardigen. De ongelijkheid tussen gerapporteerde winst en uitgekeerde bonus beïnvloedt vervolgens investeringsbeslissingen van zowel bestaande als potentiële investeerders. Dit toont aan dat winststuring in deze situatie niet het gewenste effect heeft. Omdat de waarde van niet-accounting 
gerelateerde prestatiemaatstaven in een investeringsbeslissing hoogstwaarschijnlijk samenhangt met het belang van deze informatie in een bonuscontract, hangt het effect van deze informatie op winststuringsbeslissingen af van het gewicht van deze maatstaven in een bonuscontract. Hieruit volgt de hypothese dat het gebruik van niet-accounting gerelateerde prestatiemaatstaven in CEO bonuscontracten een negatieve invloed heeft op de mate van winststuring om de waarde van de aan de CEO toegekende en toe te kennen aandelenopties te beïnvloeden.

Ik test deze hypothese voor drie optiecategorieën, te weten: nieuw verstrekte aandelenopties, niet-uitoefenbare opties en uitoefenbare opties. Ik verwacht meer winststuring rond de datum waarop opties verstrekt worden en de datum waarop opties uitgeoefend worden, omdat winststuring een tijdelijk effect op een aandelenprijs heeft. Voor niet-uitoefenbare opties heb ik geen verwachting.

In lijn met mijn verwachtingen, vind ik dat het gebruik van niet-accounting gerelateerde prestatiemaatstaven een reducerend effect heeft op de mate van winststuring bij het uitkeren van nieuwe opties. Ik vind geen effect van het gebruik van niet-accounting gerelateerde prestatiemaatstaven voor de relatie tussen winststuring en uitoefenbare opties. Dit resultaat kan verklaard worden door de gedachte dat uitoefenbare aandelenopties meer waard worden bij een stijgende aandelenprijs die wellicht moeilijker te bewerkstelligen is met winststuring dan een dalende aandelenprijs. Daarnaast is winststuring bij het uitoefenen van aandelenopties niet altijd noodzakelijk, omdat een uitoefenperiode zich over langere tijd uitstrekt waarin zich met grote waarschijnlijkheid ook een periode met een hoge aandelenprijs bevindt. In mijn analyse controleer ik voor de mogelijkheid dat het gebruik van niet-accounting gerelateerde prestatiemaatstaven samenhangt met de informativiteit van accounting gerelateerde prestatiemaatstaven, waardoor winststuring ook geen effect zou hebben op de aandelenprijs. Hiermee laat ik zien dat het gebruik van niet-accounting gerelateerde prestatiemaatstaven in de bonusuitkering van de leden van de raad van bestuur een disciplinerend effect heeft op optiegerelateerde winststuringsbeslissingen.

De resultaten in hoofdstuk 3 en 4 tonen het belang van de jaarlijkse bonusuitkering aan. Dit resultaat moet gezien worden in het licht van het feit dat de vermogenseffecten van bonusuitkeringen voor managers ten opzichte van toegekende aandelen- en optierechten een steeds kleinere waarde vertegenwoordigen. Als gevolg hiervan werd het belang van bonusuitkeringen in de academische literatuur recentelijk ter discussie gesteld. Het onderzoek in dit proefschrift laat zien dat bonusuitkeringen wel degelijk van waarde zijn voor zowel management als aandeelhouders.

Bovendien laten de resultaten in hoofdstuk 3 en 4 zien dat een gedetailleerde beschrijving van het beloningsysteem van de CEO van waarde is voor zowel bestaande als potentiële investeerders. De Nederlandse corporate governance 
code (code Tabaksblat) spoort in Nederland beursgenoteerde vennootschappen aan, deze informatie in de toelichting op de jaarrekening voor te leggen. De code schrijft voor dat deze vennootschappen de prestatiecriteria van variabele bezoldigingscomponenten beschrijven en verantwoorden. Daarnaast dienen deze venootschappen de methoden te beschrijven die zullen worden gehanteerd om vast te stellen of aan deze prestatiecriteria voldaan is. Deze methoden dienen ook verantwoord te worden. De naleving van de code is gebaseerd op de "pas toe of leg uit" regel. Dit betekent dat de uitleg van eventuele afwijkingen van codebepalingen adequaat gemotiveerd dient te worden. De resultaten in hoofdstuk 3 en 4 van dit proefschrift illustreren het gebruik van deze informatie door de kapitaalmarkt en tonen daarmee het belang aan van de codebepalingen en de handhaving van het bezoldigingshoofdstuk van de code Tabaksblat. 


\section{Curriculum Vitae}

Robbert-Paul Roomberg was born on 23 December 1978 in Sittard, the Netherlands. From 1997 to 2002 he studied International Business Studies at the Faculty of Economics and Business Administration of Maastricht University. After graduation, he continued working at the Department of Accounting and Information Management of Maastricht University. Since April 2007 he is working for PricewaterhouseCoopers in Germany. He started as a trainee in the Deal Services program and he joined the Transaction Services Department in Frankfurt am Main as of April 2008. 